\title{
Review Article \\ Religion, Spirituality, and Health: The Research and Clinical Implications
}

\author{
Harold G. Koenig ${ }^{1,2}$ \\ ${ }^{1}$ Departments of Medicine and Psychiatry, Duke University Medical Center, P.O. Box 3400, Durham, NC 27705, USA \\ ${ }^{2}$ Department of Medicine, King Abdulaziz University, Jeddah 21413, Saudi Arabia
}

Correspondence should be addressed to Harold G. Koenig, harold.koenig@duke.edu

Received 25 September 2012; Accepted 15 October 2012

Academic Editors: S. M. Hyman and B. J. Mitterauer

Copyright (C) 2012 Harold G. Koenig. This is an open access article distributed under the Creative Commons Attribution License, which permits unrestricted use, distribution, and reproduction in any medium, provided the original work is properly cited.

\begin{abstract}
This paper provides a concise but comprehensive review of research on religion/spirituality (R/S) and both mental health and physical health. It is based on a systematic review of original data-based quantitative research published in peer-reviewed journals between 1872 and 2010, including a few seminal articles published since 2010. First, I provide a brief historical background to set the stage. Then I review research on R/S and mental health, examining relationships with both positive and negative mental health outcomes, where positive outcomes include well-being, happiness, hope, optimism, and gratefulness, and negative outcomes involve depression, suicide, anxiety, psychosis, substance abuse, delinquency/crime, marital instability, and personality traits (positive and negative). I then explain how and why R/S might influence mental health. Next, I review research on R/S and health behaviors such as physical activity, cigarette smoking, diet, and sexual practices, followed by a review of relationships between $\mathrm{R} / \mathrm{S}$ and heart disease, hypertension, cerebrovascular disease, Alzheimer's disease and dementia, immune functions, endocrine functions, cancer, overall mortality, physical disability, pain, and somatic symptoms. I then present a theoretical model explaining how R/S might influence physical health. Finally, I discuss what health professionals should do in light of these research findings and make recommendations in this regard.
\end{abstract}

\section{Historical Background and Introduction}

Religion, medicine, and healthcare have been related in one way or another in all population groups since the beginning of recorded history [1]. Only in recent times have these systems of healing been separated, and this separation has occurred largely in highly developed nations; in many developing countries, there is little or no such separation. The history of religion, medicine, and healthcare in developed countries of the West, though, is a fascinating one. The first hospitals in the West for the care of the sick in the general population were built by religious organizations and staffed by religious orders. Throughout the Middle Ages and up through the French Revolution, physicians were often clergy. For hundreds of years, in fact, religious institutions were responsible for licensing physicians to practice medicine. In the American colonies, in particular, many of the clergy were also physicians-often as a second job that helped to supplement their meager income from church work.
Care for those with mental health problems in the West also had its roots within monasteries and religious communities [2]. In 1247, the Priory of St. Mary of Bethlehem was built in London on the Thames River [3]. Originally designed to house "distracted people," this was Europe's (and perhaps the world's) first mental hospital. In 1547, however, St. Mary's was torn down and replaced by Bethlehem or Bethlem Hospital [4]. Over the years, as secular authorities took control over the institution, the hospital became famous for its inhumane treatment of the mentally ill, who were often chained [5], dunked in water, or beaten as necessary to control them. In later years, an admission fee ( 2 pence) was charged to the general public to observe the patients abusing themselves or other patients [4]. The hospital eventually became known as "bedlam" (from which comes the word used today to indicate a state of confusion and disarray).

In response to the abuses in mental hospitals, and precipitated by the death of a Quaker patient in New York asylum in England, an English merchant and devout Quaker 
named William Tuke began to promote a new form of treatment of the mentally ill called "moral treatment." In 1796, he and the Quaker community in England established their own asylum known as the York Retreat [6]. Not long after this, the Quakers brought moral treatment to America, where it became the dominant form of psychiatric care in that country [6]. Established in Philadelphia by the Quakers in 1813, "Friends Hospital" (or Friends Asylum) became the first private institution in the United States dedicated solely to the care of those with mental illness [7]. Psychiatric hospitals that followed in the footsteps of Friends Asylum were the McLean Hospital (established in 1818 in Boston, and now associated with Harvard), the Bloomingdale Asylum (established in 1821 in New York), and the Hartford Retreat (established in 1824 in Connecticut) - all modeled after the York Retreat and implementing moral treatment as the dominant therapy.

It was not until modern times that religion and psychiatry began to part paths. This separation was encouraged by the psychiatrist Sigmund Freud. After being "introduced" to the neurotic and hysterical aspects of religion by the famous French neurologist Jean Charcot in the mid-1880s, Freud began to emphasize this in a widely read series of publications from 1907 through his death in 1939. Included among these were Religious Acts and Obsessive Practices [8], Psychoanalysis and Religion [9], Future of an Illusion [10], and Moses and Monotheism [11]. These writings left a legacy that would influence the practice of psychiatry-especially psychotherapy-for the rest of the century and lead to a true schism between religion and mental health care. That schism was illustrated in 1993 by a systematic review of the religious content of DSM-III-R, which found nearly onequarter of all cases of mental illness being described using religious illustrations [12]. The conflict has continued to the present day. Consider recent e-letters in response to two articles published in The Psychiatrist about this topic [13, 14] and an even more recent debate about the role of prayer in psychiatric practice [15]. This conflict has manifested in the clinical work of many mental health professionals, who have generally ignored the religious resources of patients or viewed them as pathological. Consider that a recent national survey of US psychiatrists found that $56 \%$ said they never, rarely, or only sometimes inquire about religious/spiritual issues in patients with depression or anxiety [16]. Even more concerning, however, is that the conflict has caused psychiatrists to avoid conducting research on religion and mental health. This explains why so little is known about the relationship between religious involvement and severe mental disorders (see Handbook of Religion and Health) [17].

Despite the negative views and opinions held by many mental health professionals, research examining religion, spirituality, and health has been rapidly expanding-and most of it is occurring outside the field of psychiatry. This research is being published in journals from a wide range of disciplines, including those in medicine, nursing, physical and occupational therapy, social work, public health, sociology, psychology, religion, spirituality, pastoral care, chaplain, population studies, and even in economics and law journals. Most of these disciplines do not readily communicate with

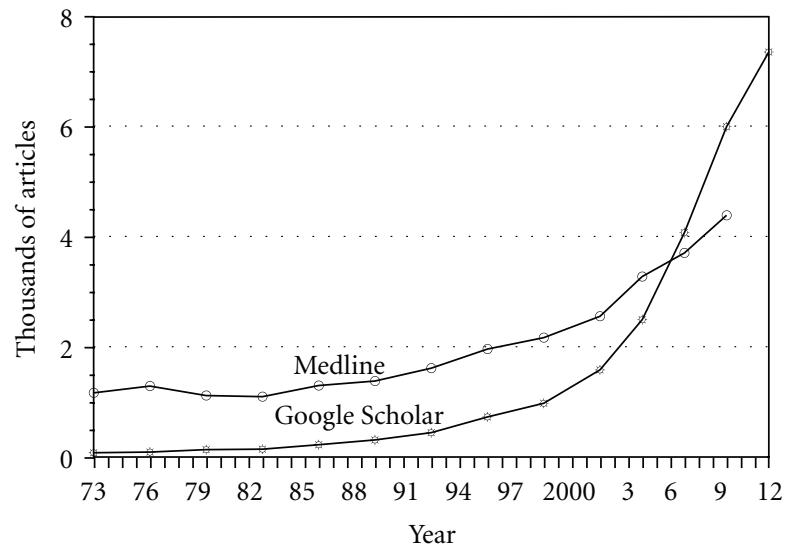

Figure 1: Religion spirituality and health articles published per 3-year period (noncumulative) Search terms: religion, religious, religiosity, religiousness, and spirituality (conducted on $8 / 11 / 12$; projected to end of 2012).

each another, and their journal audiences seldom overlap. The result is a massive research literature that is scattered throughout the medical, social, and behavioral sciences.

To get a sense of how rapidly the research base is growing see Figure 1. The graphs plot the number of studies published in peer-reviewed journals during every noncumulative 3-year period from 1971 to 2012. Note that about $50 \%$ of these articles are reports of original research with quantitative data, whereas the other $50 \%$ are qualitative reports, opinion pieces, reviews, or commentaries. Google Scholar presents a more comprehensive picture since it includes studies published in both Medline and non-Medline journals. These graphs suggest that the volume of research on $\mathrm{R} / \mathrm{S}$ and health has literally exploded since the mid-1990s.

\section{Definitions}

Before summarizing the research findings, it is first necessary to provide definitions of the words religion and spirituality that I am using. There is much controversy and disagreement concerning definitions in this field, particularly over the term "spirituality," and space here does not allow a full discussion of these complex issues. For an in depth discussion, including an exploration of contamination and confounding in the measurement of spirituality, I refer the reader to other sources [18-20]. Here are the definitions we provided in the Handbook.

"[Religion] Involves beliefs, practices, and rituals related to the transcendent, where the transcendent is God, Allah, HaShem, or a Higher Power in Western religious traditions, or to Brahman, manifestations of Brahman, Buddha, Dao, or ultimate truth/reality in Eastern traditions. This often involves the mystical or supernatural. Religions usually have specific beliefs about life after death and rules about conduct within a social group. Religion is a multidimensional construct that includes beliefs, behaviors, rituals, and ceremonies that may be held or practiced in private or 
public settings, but are in some way derived from established traditions that developed over time within a community. Religion is also an organized system of beliefs, practices, and symbols designed (a) to facilitate closeness to the transcendent, and (b) to foster an understanding of one's relationship and responsibility to others in living together in a community." [21].

"Spirituality is distinguished from all other thingshumanism, values, morals, and mental health-by its connection to that which is sacred, the transcendent. The transcendent is that which is outside of the self, and yet also within the self-and in Western traditions is called God, Allah, HaShem, or a Higher Power, and in Eastern traditions may be called Brahman, manifestations of Brahman, Buddha, Dao, or ultimate truth/reality. Spirituality is intimately connected to the supernatural, the mystical, and to organized religion, although also extends beyond organized religion (and begins before it). Spirituality includes both a search for the transcendent and the discovery of the transcendent and so involves traveling along the path that leads from nonconsideration to questioning to either staunch nonbelief or belief, and if belief, then ultimately to devotion and finally, surrender. Thus, our definition of spirituality is very similar to religion and there is clearly overlap." [22].

For the research review presented here, given the similarity in my definition of these terms and the fact that spirituality in the research has either been measured using questions assessing religion or by items assessing mental health (thereby contaminating the construct and causing tautological results), I will be using religion and spirituality interchangeably (i.e., R/S).

\section{Method of the Review}

I summarize the research findings between $\mathrm{R} / \mathrm{S}$ and health first in the area of mental health outcomes, then for health behaviors, and finally for physical health outcomes. The information presented here is based on a systematic review of peer-reviewed original data-based reports published though mid-2010 and summarized in two editions of the Handbook of Religion and Health [23, 24]. How these systematic reviews were conducted, however, needs brief explanation. This is particularly true for ratings of study methodology that are used to summarize the findings below.

The systematic review to identify the studies presented in the Handbooks and summarized in this paper was conducted as follows. We utilized a combination of strategies to identify the studies (excluding most reviews or qualitative research). First, we systematically searched online databases (PsycINFO, MEDLINE, etc.) using the search words "religion," "religiosity," "religiousness," and "spirituality" to identify studies on the R/S-health relationship. Second, we asked prominent researchers in the field to alert us to published research they knew about and to send us research that they themselves had conducted. Third, if there were studies cited in the reference lists of the studies located, we tracked down those as well. Using this method, we identified over 1,200 quantitative original data-based publications during the period 1872 to 2000 and 2,100 studies examining the R/S-health relationship from 2000 to 2010 . All of these studies are described in the appendices of the two editions of the Handbook. Based on other reviews of the research conducted around this same time period (but more limited), we estimate that our review captured about $75 \%$ of the published research. Bear in mind that many, many more qualitative studies have been published on the topic that were not included in this review.

In order to assess the methodological quality of the studies, quality ratings were assigned as follows. Ratings of each of the more than 3,300 studies were made on a scale from 0 (low) to 10 (high) and were performed by a single examiner (HGK) to ensure rating consistency. Scores were determined according to the following eight criteria: study design (clinical trial, prospective cohort, crosssectional, etc.), sampling method (random, systematic, or convenience), number of $\mathrm{R} / \mathrm{S}$ measures, quality of measures, quality of mental health outcome measure, contamination between R/S measures and mental health outcomes, inclusion of control variables, and statistical method, based on a scheme adapted from Cooper [25]. Cooper emphasized the definition of variables, validity and reliability of measures, representativeness of the sample (sample size, sampling method, and response rates), research methods (quality of experimental manipulation and adequacy of control group for clinical trials), how well the execution of the study conformed to the design, appropriateness of statistical tests (power, control variables), and the interpretation of results.

To assess the reliability of the ratings, we compared HGK's ratings on 75 studies with the ratings made by an independent outside reviewer (Andrew Futterman, Ph.D., professor of psychology, College of the Holy Cross, a scientist familiar with the scoring criteria and active in the field of $\mathrm{R} / \mathrm{S}$-health research). When we examined correlations between HGK and Futterman's ratings, we found them moderately correlated (Pearson $r=0.57$ ). Since scores of 7 or higher indicated higher quality studies, we also compared the scores between the two raters in terms of lower $(0-6)$ versus higher (7-10) quality. This was done by dichotomizing scores into two categories (0-6 versus 7-10) and comparing the categories between the two examiners. The kappa of agreement $(\kappa)$ between the two raters was 0.49 (where kappas of 0.40 to 0.75 indicate good agreement [26]). Overall, the raters agreed on whether quality was low or high in 56 of the 75 studies or $75 \%$. I now summarize the results of the systematic review described above.

\section{Religion, Spirituality, and Mental Health}

Approximately $80 \%$ of research on $\mathrm{R} / \mathrm{S}$ and health involves studies on mental health. One would expect stronger relationships between $\mathrm{R} / \mathrm{S}$ and mental health since $\mathrm{R} / \mathrm{S}$ involvement consists of psychological, social, and behavioral aspects that are more "proximally" related to mental health than to physical health. In fact, we would not expect any direct or immediate effects of R/S on physical health, other than indirectly through intermediary psychosocial 
and behavioral pathways. With regard to mental health, we would expect R/S to boost positive emotions and help neutralize negative emotions, hypothesizing that it serves as both a life-enhancing factor and as a coping resource. With regard to the latter, there is both qualitative and quantitative research suggesting that R/S helps people to deal better with adversity, either external adversity (difficult environmental circumstances) or internal adversity (genetic predisposition or vulnerability to mental disorders).

In the present paper, I have chosen to cite original reports as examples of the most rigorous studies in each area based on ratings in the Handbooks (i.e., 7 or higher on $0-10$ scale). Cited here are both positive and negative studies reporting significant relationships. For some topics, such as well-being and depression, there are too many high-quality studies to cite, so only a few examples of the best studies are provided.

4.1. Coping with Adversity. In the first edition of the Handbook [27], we identified 110 studies published prior to the year 2000 and 344 studies published between 2000 and 2010 for a total of 454 studies. Among these reports are descriptions of how R/S helped people to cope with a wide range of illnesses or in a variety of stressful situations. These include people dealing with general medical illness $[28,29]$, chronic pain [30], kidney disease [31], diabetes $[32,33]$, pulmonary disease $[34]$, cancer $[35,36]$, blood disorders [37], heart/cardiovascular diseases [38, 39], dental [40] or vision [41] problems, neurological disorders [42], HIV/AIDS [43], systemic lupus erythematosus [44], irritable bowel syndrome [45], musculoskeletal disease [46], caregiver burden [47-49], psychiatric illness [50, 51], bereavement $[52,53]$, end-of-life issues $[54,55]$, overall stress [56-58], natural disasters $[59,60]$, war $[61,62]$ or acts of terrorism [63], and miscellaneous adverse life situations [64-66]. In the overwhelming majority of studies, people reported that R/S was helpful.

4.2. Positive Emotions. Positive emotions include well-being, happiness, hope, optimism, meaning and purpose, high selfesteem, and a sense of control over life. Related to positive emotions are positive psychological traits such as altruism, being kind or compassionate, forgiving, and grateful.

4.2.1. Well-Being/Happiness. By mid-2010, at least 326 quantitative, peer-reviewed studies had examined relationships with R/S. Of those, 256 (79\%) found only significant positive associations between R/S and well-being (including eight studies at a statistical trend level, that is, $0.05<P<0.10$ ). Only three studies $(<1 \%)$ reported a significant inverse relationship between R/S and well-being. Of the 120 studies with the highest methodological rigor (7 or higher in quality on the $0-10$ scale), 98 ( $82 \%$ ) reported positive relationships (including two at a trend level) [67-77] and one study reported a negative relationship (but only at a trend level) [78].

4.2.2. Hope. At least 40 studies have examined relationships with R/S, and of those, 29 (73\%) reported only significant positive relationships with degree of hope; no studies found an inverse relationship. Of the six highest quality studies, half found a positive relationship [79-81].

4.2.3. Optimism. We located 32 studies examining relationships with R/S, and of those, 26 (81\%) reported significant positive relationships. Of the 11 best studies, eight (73\%) reported significant positive relationships [82-85]. Again, as with hope, no studies reported inverse relationships.

4.2.4. Meaning and Purpose. At least 45 studies have examined relationships with $\mathrm{R} / \mathrm{S}$, and $42(93 \%)$ reported significant positive relationships. These studies were often in populations where there was a challenge to having meaning and purpose, such as in people with chronic disabling illness. Of the 10 studies with quality ratings of 7 or higher, all 10 reported significant positive associations [86-89].

4.2.5. Self-Esteem. Critics have claimed that R/S adversely affects self-esteem because it emphasizes humility rather than pride in the self [90]. Furthermore, R/S could exacerbate guilt in some for not living up to the high standards of conduct prescribed by religious traditions, resulting in low self-esteem. We found 69 studies that examined associations with R/S, and of those, $42(61 \%)$ found greater selfesteem among those who were more R/S and two (3\%) reported lower self-esteem. Of the 25 studies with the highest methodological rigor, 17 (68\%) reported greater self-esteem [91-98] and two (8\%) found worse self-esteem [99, 100]. Not surprisingly, these findings are parallel to those of depression below (in the opposite direction, of course).

4.2.6. Sense of Control. Although one might expect R/S to correlate positively with an external locus of control (i.e., the Transcendent controlling events), and some studies confirm this, the majority of research finds a positive correlation with an internal not an external sense of control. Of 21 studies that have examined these relationships, 13 (61\%) found that $\mathrm{R} / \mathrm{S}$ was related to a greater sense of personal control in challenging life circumstances. Of the nine best studies, four reported significant positive relationships (44\%) [101-104] and three report significant negative relationships (33\%) [105-107], whereas the two remaining studies reported complex or mixed results (significant positive and negative associations, depending on R/S characteristic). R/S beliefs may provide an indirect sense of control over stressful situations; by believing that God is in control and that prayer to God can change things, the person feels a greater sense of internal control (rather than having to depend on external agents of control, such as powerful other people).

4.2.7. Positive Character Traits. With regard to character traits, the findings are similar to those with positive emotions. With regard to altruism or frequency of volunteering, 47 studies have examined relationships with R/S. Of those, 33 (70\%) reported significant associations, whereas five $(11 \%)$ found less altruism among the more R/S; of the 20 best studies, $15(75 \%)$ reported positive relationships [108-113] 
and two (10\%) found negative associations [114, 115] (both concerning organ donations, which some religions prohibit). With regard to forgiveness, 40 studies have examined correlations with R/S, and 34 (85\%) reported significant positive relationships and no studies found negative associations. Among the 10 highest quality studies, seven (70\%) reported greater forgiveness among the more R/S [116-119], a finding that recent research has supported [120]. Regarding gratefulness, five of five studies found positive associations with $\mathrm{R} / \mathrm{S}$ $[121,122]$, and with regard to kindness/compassion, three of three studies reported significant positive relationship with $\mathrm{R} / \mathrm{S}$ [123]. Admittedly, all of the studies measuring character traits above depend on self-report.

4.3. Depression. As with self-esteem, mental health professionals have argued that $\mathrm{R} / \mathrm{S}$ might increase guilt by focusing on sin and could thus lead to depression. Again, however, this has not been found in the majority of studies. Given the importance of depression, its wide prevalence in the population, and the dysfunction that it causes (both mental and physical), I describe the research findings in a bit more detail. Overall, at least 444 studies have now examined relationships between $\mathrm{R} / \mathrm{S}$ and depression, dating back to the early 1960s. Of those, 272 (61\%) reported significant inverse relationships with depression (including nine studies at a trend level), and $28(6 \%)$ found relationships between $\mathrm{R} / \mathrm{S}$ and greater depression (including two studies at a trend level). Of the 178 studies with the highest methodological rigor, $119(67 \%)$ reported inverse relationships [124-135] and $13(7 \%)$ found positive relationships with depression [136-148].

Of 70 prospective cohort studies, 39 (56\%) reported that greater R/S predicted lower levels of depression or faster remission of depression, whereas seven $(10 \%)$ predicted worse future depression and seven (10\%) reported mixed results (both significant positive and negative associations depending on $\mathrm{R} / \mathrm{S}$ characteristic). Of 30 clinical trials, $19(63 \%)$ found that R/S interventions produced better outcomes than either standard treatment or control groups. Two studies (7\%) found standard treatments were superior to $R / S$ interventions $[149,150]$ and one study reported mixed results.

Note that an independent review of this literature published in 2003 found that of 147 studies involving 98,975 subjects, the average correlation between $\mathrm{R} / \mathrm{S}$ and depression was -0.10 . Although this is a small correlation, it translates into the same effect size that gender has on depressive symptoms (with the rate of depression being nearly twice as common in women compared to men). Also, the average correlation reported in the 2003 review was 50\% stronger in stressed versus nonstressed populations [151].

A widely renowned psychiatric epidemiology group at Columbia University, led by Lisa Miller and Myrna Weissman, has come out with a series of recent reports on $\mathrm{R} / \mathrm{S}$ and depression studying a cohort of low- and highrisk children born to parents with and without depressive disorder. The findings from this cohort support an inverse link between $\mathrm{R} / \mathrm{S}$ and depression, particularly in high-risk individuals [152-154].

4.4. Suicide. Correlations between $\mathrm{R} / \mathrm{S}$ and suicide attempt, completed suicide, and attitudes toward suicide are consistent with those found for depression, self-esteem, and hope. Those who are depressed, without hope, and with low self-esteem are at greater risk for committing suicide. At least 141 studies have now examined relationships between $\mathrm{R} / \mathrm{S}$ and the suicide variables above. Of those, $106(75 \%)$ reported inverse relationships and four (3\%) found positive relationships. With regard to the 49 studies with the highest methodological rigor, $39(80 \%)$ reported less suicide, fewer suicide attempts, or more negative attitudes toward suicide among the more R/S [155-170] and two (4\%) found positive relationships (one study in Delhi, India [171], and one in college students distressed over R/S concerns [172]).

4.5. Anxiety. Anxiety and fear often drive people toward religion as a way to cope with the anxiety. Alternatively, R/S may increase anxiety/fear by its threats of punishment for evil deeds and damnation in the next life. There is an old saying that emphasizes this dual role: religion comforts the afflicted and afflicts the comforted. Sorting out cause and effect here is particularly difficult given the few prospective cohort studies that have examined this relationship over time. However, a number of clinical trials have also examined the effects of R/S interventions on anxiety levels. Overall, at least 299 studies have examined this relationship, and of those, 147 (49\%) reported inverse association with R/S (three at a trend level), whereas $33(11 \%)$ reported greater anxiety in those who were more R/S. Of the latter, however, only one was a prospective study, one was a randomized clinical trial, and $31(94 \%)$ were cross-sectional studies (where it was not clear whether R/S caused anxiety or whether anxiety increased $\mathrm{R} / \mathrm{S}$ as a coping response to the anxiety). Of the 67 studies with quality ratings of seven or higher, 38 (55\%) reported inverse relationships [173-182] and seven (10\%) found positive relationships (greater anxiety among the more $\mathrm{R} / \mathrm{S})$ [183-189].

Among these 299 studies were 239 cross-sectional studies, 19 prospective cohort studies, 9 single-group experimental studies, and 32 randomized clinical trials. Of the 19 longitudinal studies, $9(47 \%)$ reported that R/S predicted a lower level of anxiety over time; one study (5\%) found an increase in anxiety (among women undergoing abortion for fetal anomaly) [189], seven reported no association, and two reported mixed or complex results. Of the nine experimental studies, seven (78\%) found a reduction in anxiety following an $\mathrm{R} / \mathrm{S}$ intervention (before versus after comparison). Of the 32 randomized clinical trials, $22(69 \%)$ reported that an $\mathrm{R} / \mathrm{S}$ intervention reduced anxiety more than a standard intervention or control condition, whereas one study (3\%) found an increase in anxiety following an R/S intervention in persons with severe alcohol dependence [190].

4.6. Psychotic Disorder/Schizophrenia. We identified 43 studies that have examined relationships between $\mathrm{R} / \mathrm{S}$ and 
chronic psychotic disorders such as schizophrenia. Of the 43 studies examining psychosis, 14 (33\%) reported inverse relationships between R/S and psychotic symptoms (one at a trend level), 10 (23\%) found a positive relationship between R/S and psychotic symptoms (one at a trend level), eight reported mixed results (significant negative and positive associations, depending on the R/S characteristic measured), and one study reported complex results. Of these studies, seven had quality ratings of seven or higher; of those, two found inverse relationships, two found positive relationship, two reported mixed results (negative and positive), and one found no association. Note that the two studies finding inverse relationships between R/S and psychosis were both prospective studies [191-193], finding that R/S predicted better outcomes in subjects with psychotic disorders or symptoms. Of the two studies reporting positive relationships (both cross-sectional), one study found that importance of religion was significantly and positively associated with religious delusions [194] (not surprising), and the other study found that importance of religion was associated with "psychotic-like" symptoms in a national sample of Mexican Americans [195]; since the latter study involved participants who were not mentally ill, religion-related cultural factors may have influenced this finding. For a recent and more comprehensive discussion of R/S, schizophrenia, other chronic psychotic disorders, and the challenges distinguishing psychotic symptoms from religious beliefs, the reader is referred elsewhere [196].

4.7. Bipolar Disorder. Despite it's importance and wide prevalence, we could locate only four studies examining the relationship between $\mathrm{R} / \mathrm{S}$ and bipolar (BP) disorder. Two found a positive association between R/S and bipolar disorder, and the remaining two reported mixed findings (both positive and negative correlations, depending on R/S characteristic). Of the two studies with high-quality ratings, one found a positive association and the other reported mixed findings. The first study of 334 US veterans with $\mathrm{BP}$ disorder found that a higher frequency of prayer or meditation was associated with mixed states and a lower likelihood of euthymia, although no association was found between any religious variable and depression or mania [197]. A second study examined a random national sample of 37,000 Canadians and found that those who attributed greater importance to higher spiritual values were more likely to have BP disorder, whereas higher frequency of religious attendance was associated with a lower risk of disorder [198]. In a qualitative study of 35 adults with bipolar disorder (not included in the review above), one of the six themes that participants emphasized when discussing their quality of life was the spiritual dimension. Over one-third of participants in that study talked about the relationship between BP disorder and $\mathrm{R} / \mathrm{S}$, emphasizing struggles to disentangle genuine spiritual experiences from the hyperreligiosity of the disorder. In another report, a case of mania precipitated by Eastern meditation was discussed; also included in this article was a review of nine other published cases of psychosis occurring in the setting of meditation [199].
4.8. Personality Traits. Personality traits most commonly measured today in psychology are the Big Five: extraversion, neuroticism, conscientiousness, agreeableness, and openness to experience. These are assessed by the NEO Personality Inventory [200]. Another personality inventory commonly used in the United Kingdom is the Eysenck Personality Questionnaire, which assesses extraversion, neuroticism, and psychoticism [201]. Relationships between personality traits and R/S using these measures have been examined in many studies [202]. With regard to psychoticism (a trait that assesses risk taking or lack of responsibility, rather than psychotic symptoms), 19 studies have examined its relationship to R/S, with $84 \%$ of those reporting significant inverse relationships (and no studies reporting a positive relationship). There have been at least 54 quantitative studies examined relationships between $\mathrm{R} / \mathrm{S}$ and neuroticism, of which $24 \%$ found an inverse relationship and $9 \%$ reported a positive relationship (most of the remaining found no association). Concerning extraversion, there have been 50 studies, with 38\% reporting a positive relationship with R/S and 6\% reporting an inverse or negative relationship. With regard to conscientiousness, there have been 30 studies, of which the majority $(63 \%)$ reported significant positive relationships with R/S and only $3 \%$ found significant inverse relationships. For agreeableness, 30 studies have examined relationships with $\mathrm{R} / \mathrm{S}$, and $87 \%$ of these studies reported positive relationships (no studies report inverse relationships). Finally, there have been 26 studies examining openness to experience, and of those, $42 \%$ found positive relationships with R/S and $12 \%$ reported negative relationships. Thus, $\mathrm{R} / \mathrm{S}$ persons tend to score lower on psychoticism and neuroticism, and higher on extraversion, conscientiousness, agreeableness, and openness to experience. They score especially low on psychoticism and especially high on agreeableness and conscientiousness. These personality traits have physical health consequences that we are only beginning to recognize [203-205].

4.9. Substance Abuse. If $\mathrm{R} / \mathrm{S}$ influences one domain of mental health, it is in the area of substance abuse. With regard to alcohol use, abuse, and dependence, at least 278 studies have now examined relationships with R/S. Of those, 240 $(86 \%)$ reported inverse relationships and only 4 studies (1\%) indicated a positive relationship. Of the 145 studies with the best methodology, 131 (90\%) reported inverse relationships [206-221] and only one study found a positive relationship [222]. Findings are similar with regard to drug use or abuse. We located 185 studies, of which $84 \%$ reported inverse relationship with R/S and only two studies (1\%) found positive relationships. Of the 112 best studies, 96 (86\%) reported inverse relationships [223-238] and only one study found a positive relationship [239]. The vast majority of these studies are in young persons attending high school or college, a time when they are just starting to establish substance use habits (which for some will interfere with their education, future jobs, family life, and health). Thus, the protective effects of R/S on substance abuse may have influences on health across the lifespan. 
4.10. Social Problems. Here I examine research in two areas of social instability (delinquency/crime and marital instability) and two areas of social stability (social support and social capital). Given the emphasis that most major world religions place on human relationships, love, and compassion, one might expect that some of the strongest relationships with $\mathrm{R} / \mathrm{S}$ would be found here, and they are indeed.

4.10.1. Delinquency/Crime. At least 104 studies have examined relationships with R/S. Of those, 82 (79\%) reported significant inverse relationships (five at a trend level), whereas three $(3 \%)$ found positive relationships with more delinquency/crime. Of the 60 studies with quality ratings of 7 or higher, 49 (82\%) reported inverse relationships [240-252] and only one study found a positive relationship [253]. Of particular interest are the 10 studies examining relationships between R/S and school grades/performance in adolescents and college students between 2000 and 2009, of which all $10(100 \%)$ found that more R/S youth did better than less religious youth [254].

4.10.2. Marital Instability. We identified 79 studies that examined relationships with marital instability. Of those, $68(86 \%)$ found R/S related to greater marital stability and no studies reported an association with greater marital instability. Of the 38 methodologically most rigorous studies, 35 (92\%) reported significant relationships between R/S and greater marital stability [255-265]. An independent meta-analysis reviewing research conducted before the year 2000 likewise concluded that greater religiousness decreased the risk of divorce and facilitated marital functioning and parenting [266].

4.10.3. Social Support. There is substantial evidence indicating a relationship between R/S and social support. Of 74 quantitative peer-reviewed studies of R/S and social support, $61(82 \%)$ found significant positive relationships, and none found inverse relationships. Of the 29 best studies, 27 (93\%) reported significant positive relationships [82, 267-274]. For older adults in particular, the most common source of social support outside of family members comes from members of religious organizations $[275,276]$.

4.10.4. Social Capital. Social capital, an indirect measure of community health, is usually assessed by level of community participation, volunteerism, trust, reciprocity between people in the community, and membership in community-based, civic, political, or social justice organizations. Research has examined relationships between R/S and social capital. We located a total of 14 studies, with 11 (79\%) finding significant positive relationships between R/S and level of social capital, and none reporting only inverse relationships. Almost all of these studies were of high quality, and of the 13 studies with ratings of seven or higher, 10 (77\%) found that R/S was related to greater social capital [277-280].

\section{Explaining the Relationship: $R / S$ and Mental Health}

$\mathrm{R} / \mathrm{S}$ influences mental health through many different mechanisms, although the following are probably the predominant ones (see Figure 2). First, religion provides resources for coping with stress that may increase the frequency of positive emotions and reduce the likelihood that stress will result in emotional disorders such as depression, anxiety disorder, suicide, and substance abuse. Religious coping resources include powerful cognitions (strongly held beliefs) that give meaning to difficult life circumstances and provide a sense of purpose. Religions provide an optimistic worldview that may involve the existence of a personal transcendental force (God, Allah, Jehovah, etc.) that loves and cares about humans and is responsive to their needs. These cognitions also give a subjective sense of control over events (i.e., if God is in control, can influence circumstances, and be influenced by prayer, then prayer by the individual may positively influence the situation). Religious beliefs provide satisfying answers to existential questions, such as "where did we come from," "why are we here," and "where are we going," and the answers apply to both this life and the next life, thus reducing existential angst. These beliefs also help to normalize loss and change and provide role models of persons suffering with the same or similar problems (often illustrated in religious scriptures). Thus, religious beliefs have the potential to influence the cognitive appraisal of negative life events in a way that makes them less distressing. For people with medical illness, these beliefs are particularly useful because they are not lost or impaired with physical disability - unlike many other coping resources that are dependent on health (hobbies, relationships, and jobs/finances).

Second, most religions have rules and regulations (doctrines) about how to live life and how to treat others within a social group. When individuals abide by those rules and regulations, this reduces the likelihood of stressful life events that reduce positive emotions and increased negative ones. Examples of stressful life events that religion may help people avoid are divorce or separation, difficulties with children, financial stress resulting from unfair practices in the marketplace, incarceration for lawbreaking (cheating or crime), and venereal diseases from risky sexual practices. Religions also usually discourage the use of drugs and excessive amounts of alcohol that increases the risk of engaging in the behaviors above (crime, risky sex) that are associated with negative mental health consequences.

Third, most religions emphasize love of others, compassion, and altruistic acts as well as encourage meeting together during religious social events. These prosocial behaviors have many consequences that buffer stress and lead to human support when support is needed during difficult times. Because religion encourages the helping of others and emphasizes a focus outside of the self, engagement in otherhelping activities may increase positive emotions and serve to distract from one's own problems. Religion also promotes human virtues such as honesty, forgiveness, gratefulness, patience, and dependability, which help to maintain and enhance social relationships. The practice of these human 


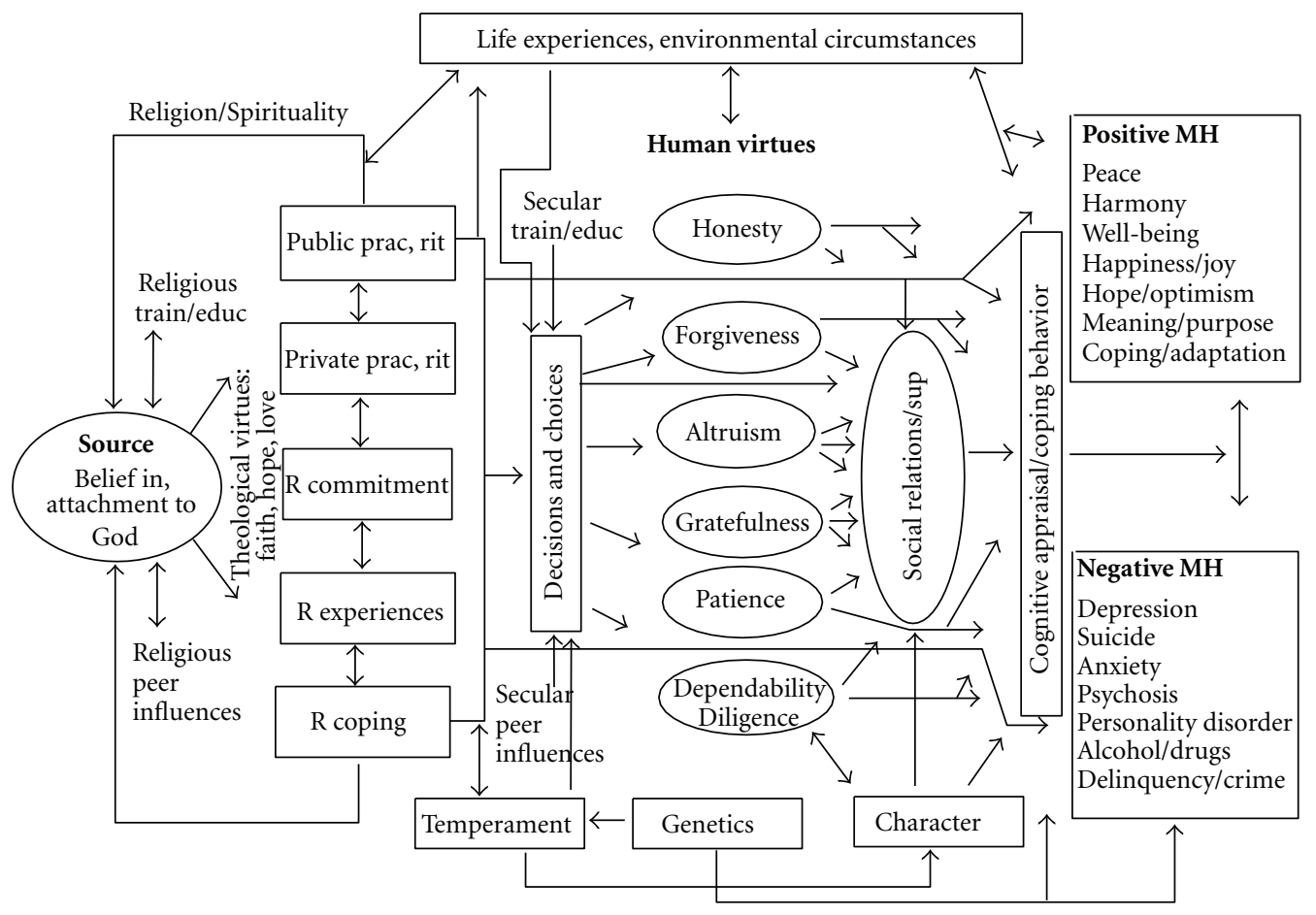

Figure 2: Theoretical model of causal pathways for mental health $(\mathrm{MH})$, based on Western monotheistic religions (Christianity, Judaism, and Islam). (Permission to reprint obtained. Original source: Koenig et al. [17]). For models based on Eastern religious traditions and the Secular Humanist tradition, see elsewhere. (Koenig et al. [24]).

virtues may also directly increase positive emotions and neutralize negative ones.

Thus, there are many possible mechanisms by which R/S may enhance mental and social health. This is not to say that $\mathrm{R} / \mathrm{S}$ always does so. Religion may also be used to justify hatred, aggression, prejudice, and the exclusion of others; gain power and control over vulnerable individuals (as seen in cults); foster rigid thinking and obsessive practices; lead to anxiety, fear, and excessive guilt over minor infractions (and even self-mutilation in some cases); produce psychosocial strains due to failure to live up to high religious standards; lead to escape from dealing with family problems (through excessive involvement in religious or spiritual activities); and delay diagnosis and effective mental health care (due to antagonistic relationships with mental health professionals). While R/S is not a panacea, on the balance, it is generally associated with greater well-being, improved coping with stress, and better mental health. This relationship with mental health has physical health consequences (see Section 7 below).

\section{Religion, Spirituality, and Health Behaviors}

Religious doctrines influence decisions about health and health behaviors. In the Judeo-Christian scriptures, for example, there is an emphasis on caring for the physical body as a "Temple of the Holy Spirit" (see 1 Corinthian 6:19-20) [281]. Religious scriptures in other faith traditions also emphasize the person's responsibility to care for and nourish their physical body [282-284]. Behaviors that have the potential to harm the body are usually discouraged. This is reflected in teachings from the pulpit and influences what is considered appropriate within religious social groups. In summarizing the research on $\mathrm{R} / \mathrm{S}$ and health behaviors, I cite only a few of the studies with high-quality ratings since there are so many.

6.1. Cigarette Smoking. The influence of R/S is most evident in it's "effects" on cigarette smoking. At least 137 studies have examined relationship between R/S and smoking, and of those, 123 (90\%) reported statistically significant inverse relationships (including three at a trend level) and no studies found either a significant or even a trend association in the other direction. Of the 83 methodologically most rigorous studies, 75 (90\%) reported inverse relationships with R/S involvement [213, 285-294]. Not surprisingly, the physical health consequences of not smoking are enormous. Decreased cigarette smoking will mean a reduction in chronic lung disease, lung cancer, all cancers (30\% being related to smoking), coronary artery disease, hypertension, stroke, and other cardiovascular diseases.

6.2. Exercise. Level of exercise and physical activity also appears linked to R/S. We located 37 studies that examined this relationship. Of those, $25(68 \%)$ reported significant positive relationships (two at a trend level) between R/S involvement and greater exercise or physical activity, whereas 
six $(16 \%)$ found significant inverse relationships. Of 21 studies with the highest quality ratings, 16 (76\%) reported positive associations $[82,295-300]$ and two (10\%) found negative associations [296, 301].

Writers in the popular press have encouraged the combining of R/S activity and exercise through "prayer walking" $[302,303]$ and "walking meditation." [304].

6.3. Diet. At least 21 studies have examined relationships between R/S and a healthy diet. A healthy diet here involves increased intake of fiber, green vegetables, fruit, and fish; low intake of snacks, processed foods, and fat; regular vitamin intake; frequent eating of breakfast; overall better nutrition (following recommended nutritional guidelines). Of those studies, $13(62 \%)$ found a significant positive association between R/S and a healthier diet (one at a trend level) and one found a worse diet [305]. Among the 10 studies with the highest quality ratings, seven (70\%) reported a better diet among those who were more R/S [213, 306310]. In addition, we identified 23 studies that examined relationships between R/S and blood cholesterol levels. Of those, more than half (12 studies) found significantly lower cholesterol among those who were more R/S, whereas three studies (13\%) reported significantly higher cholesterol levels. Of the nine best studies, five (56\%) reported lower cholesterol [311-313] or a lowering of cholesterol in response to a R/S intervention $[314,315]$, whereas one found higher cholesterol (but only in Mexican American men) [316].

6.4. Weight. Although $\mathrm{R} / \mathrm{S}$ people tend to eat a healthier diet, they also eat more of it. This, then, is the one health behavior that places R/S individuals at greater risk for medical illness. At least 36 studies have examined the associations between weight (or body mass index) and R/S involvement. Of those, 14 (39\%) found a positive relationship (R/S associated with greater weight), whereas only seven (19\%) reported an inverse relationship. The situation does not improve when results from the most rigorously designed studies are examined. Among the 25 studies with the highest quality ratings, 11 (44\%) reported greater weight among the more R/S [82, 317-322] and five (20\%) found lower weight (or less underweight [323]). Lower weight among the more R/S appears only in a few religious groups (Amish [324], Jews [325], and Buddhists [326]), in those with certain demographic characteristics (white, older, and high education) [327], and in response to a specific R/S intervention [328] or practice [314, 329]. Faith-based weight-reduction programs in religious communities have been shown to be effective [328, 330, 331].

6.5. Sexual Behavior. We identified 95 studies that examined relationships between $\mathrm{R} / \mathrm{S}$ and risky sexual activity (sex outside of marriage, multiple partners, etc.). Of those, 82 studies $(86 \%)$ found significant inverse relationships with $\mathrm{R} / \mathrm{S}$ (one at a trend level) and only one study (1\%) found a significant relationship with more risky sexual activity [332]. Of the 50 highest quality studies, 42 (84\%) reported inverse relationships [333-343] and none found a positive one. If those who are more R/S engage in less risky sexual behavior, this means they should have fewer venereal diseases, that is, less syphilis, gonorrhea, herpes, chancroid, chlamydia, viral hepatitis, and human papillomavirus and human immunodeficiency virus, many of which have serious physical health consequences.

\section{Religion, Spirituality, and Physical Health}

There is rapidly growing evidence that stress and negative emotions (depression, anxiety) have (1) adverse effects on physiological systems vital for maintenance of physical health and healing [344-346], (2) increase susceptibility to or worse outcomes from a wide range of physical illnesses [347-351], and (3) may shorten the lifespan prematurely [352, 353]. Social support, in turn, has long been known to protect against disease and increase longevity [354-356]. By reducing stress and negative emotions, increasing social support, and positively affecting health behaviors, R/S involvement should have a favorable impact on a host of physical diseases and the response of those diseases to treatment. As in the earlier sections, I cite high-quality studies as examples. Since there are fewer high-quality studies for physical health than for mental health or for health behaviors, I cite all of the studies with ratings of seven or higher.

7.1. Coronary Heart Disease (CHD). Given the strong connections between psychosocial stressors, health behaviors, and CHD, it is not surprising that there is a link with R/S. Our review uncovered 19 studies that examined associations between R/S and CHD. Of those, 12 (63\%) reported a significant inverse relationship, and one study reported a positive relationship. Of the 13 studies with the most rigorous methodology, nine (69\%) found inverse relationships with CHD [357-365] and one found a positive one [366]. In addition, there have been at least 16 studies examining relationships between $\mathrm{R} / \mathrm{S}$ and cardiovascular reactivity, heart rate variability, outcomes following cardiac surgery, and other cardiovascular functions. Of those, 11 studies (69\%) reported that R/S was significantly related to positive cardiovascular functions or outcomes [367-374] or to lower levels of inflammatory markers such as C-reactive protein [375-377] and fibrinogen [378] that place individuals at high risk for cardiovascular disease.

7.2. Hypertension. The word "hypertension" itself suggests a relationship with stress or tension, and high blood pressure has been linked to greater psychosocial stress [379-381]. At least 63 studies have examined the relationship between $\mathrm{R} / \mathrm{S}$ and blood pressure (BP), of which $36(57 \%)$ reported significantly lower BP in those who are more R/S (five at a trend level) and seven (11\%) reported significantly higher $\mathrm{BP}$ (one at a trend level). Of the 39 highest quality studies, $24(62 \%)$ report lower BP (including one at a trend level) among those who are more R/S [382-394] or in response to an R/S intervention [328, 395-404] (including a study whose 
results were reported twice, once for the overall sample and once for the sample stratified by race).

Two lower quality studies $[405,406]$ and five welldone studies [407-411] (13\%, including one at a trend level), however, reported higher $\mathrm{BP}$ in the more $\mathrm{R} / \mathrm{S}$ or with religious fasting. The reason for an association between $\mathrm{R} / \mathrm{S}$ and higher BP is not entirely clear. Perhaps, in certain population subgroups, intrapsychic religious conflict between psychosexual drives and religious standards creates unconscious stress that elevates BP. However, there is another possibility. This may be related to confounding by ethnicity. Three of the five studies reporting increased BP with increased R/S included in their samples a large proportion of ethnic minorities (samples from large urban settings such as Detroit and Chicago, made up of $36 \%$ to $100 \%$ African Americans). Since African Americans are more likely to have high BP (40\% with hypertension) [412] and because African Americans are also the most religious ethnic group in society [413], it may be that controlling for race in these analyses is simply not sufficient to overcome this powerful confound.

7.3. Cerebrovascular Disease. Relationships between R/S, hypertension and other cardiovascular diseases or disease risk factors ought to translate into a lower risk of stroke. We located nine studies that examined this relationship, of which four reported a lower risk of stroke, all having quality ratings of seven or higher [414-417].

One study, however, reported significantly more carotid artery thickening, placing $\mathrm{R} / \mathrm{S}$ individuals at higher risk for stroke [418]. Again, however, 30\% of that sample was African American an ethnic group, known to be both highly religious and at high risk for stroke.

7.4. Alzheimer's Disease and Dementia. Physiological changes that occur with stress and depression (elevated blood cortisol, in particular) are known to adversely affect the parts of the brain responsible for memory [419-421]. The experience of negative emotions may be like pouring hydrochloric acid on the brain's memory cells [422]. By reducing stress and depression through more effective coping, $\mathrm{R} / \mathrm{S}$ may produce a physiological environment that has favorable effects on cognitive functioning. Furthermore, R/S involvement may also engage higher cortical functions involved in abstract thinking (concerning moral values or ideas about the transcendent) that serve to "exercise" brain areas necessary for retention of memories. Regardless of the mechanism, at least 21 studies have examined relationships between R/S involvement and cognitive function in both healthy persons and individuals with dementia. Of those, 10 (48\%) reported significant positive relationships between $\mathrm{R} / \mathrm{S}$ and better cognitive functioning and three (14\%) found significant negative relationships. Of the 14 studies with the highest quality ratings, eight (57\%) reported positive relationships [423-430] and three (21\%) reported negative relationships with cognitive function [431-433]. Studies finding negative relationships between R/S and cognitive function may be due to the fact that R/S persons have longer lifespans (see below), increasing the likelihood that they will live to older ages when cognition tends to decline. More recent research supports a positive link between R/S and better cognitive function in both dementia and in old age [434, 435].

7.5. Immune Function. Intact immune function is critical for health maintenance and disease prevention and is assessed by indicators of cellular immunity, humoral immunity, and levels of pro- and anti-inflammatory cytokines. We identified 27 studies on relationships between R/S and immune functions, of which 15 (56\%) found positive relationships or positive effects in response to a R/S intervention, and one (4\%) found a negative effect [436]. Of the 14 studies with the highest quality ratings, $10(71 \%)$ reported significant positive associations [437-443] or increased immune functions in response to a R/S intervention [444-447]. No high-quality study found only an inverse association or negative effect, although one study reported mixed findings [448]. In that study, religious attendance was related to significantly poorer cutaneous response to antigens; however, it was also related (at a trend level) to higher total lymphocyte count, total Tcell count, and helper T-cell count. In addition, importance of religious or spiritual expression was related to significantly higher white blood cell count, total lymphocyte count, total $\mathrm{T}$ cells, and cytotoxic $\mathrm{T}$ cell activity.

There have also been a number of studies examining R/S and susceptibility to infection (or viral load in those with HIV), which could be considered an indirect measure of immune function. We identified 12 such studies, of which eight $(67 \%)$ reported significantly lower infection rates or lower viral loads in those who were more R/S (including one at a trend level); none found greater susceptibility to infection or greater viral load. Ten of the 12 studies had quality ratings of 7 or higher; of those, seven (70\%) reported significant inverse associations with infection/viral load [440, 441, 449-454].

7.6. Endocrine Function. Because stress hormones (cortisol, epinephrine, and norepinephrine) have a known influence on immune (and cardiovascular) functions, they are important factors on the pathway between R/S involvement and health $[455,456]$. We identified 31 studies that examined R/S and associations with or effects on endocrine functions. Of those, $23(74 \%)$ reported positive relationships or positive effects and no studies reported negative associations or negative effects. Of the 13 methodologically most rigorous studies, nine (69\%) reported positive associations with R/S [457-461] or positive effects of an R/S intervention (all involving Eastern meditation) [462-465]. We (at Duke) are currently examining the effects of religious cognitivebehavioral therapy on a host of pro- and anti-inflammatory cytokines, cortisol, and catecholamines in patients with major depressive disorder, although results will not be available until 2014 [466].

7.7. Cancer. At least 29 studies have examined relationships between R/S and either the onset or the outcome of cancer (including cancer mortality). Of those, $16(55 \%)$ found that those who are more R/S had a lower risk of 
developing cancer or a better prognosis, although two (7\%) reported a significantly worse prognosis $[467,468]$. Of the 20 methodologically most rigorous studies, 12 (60\%) found an association between $\mathrm{R} / \mathrm{S}$ and lower risk or better outcomes [469-480], and none reported worse risk or outcomes. The results from some of these studies can be partially explained by better health behaviors (less cigarette smoking, alcohol abuse, etc.), but not all. Effects not explained by better health behaviors could be explained by lower stress levels and higher social support in those who are more R/S. Although cancer is not thought to be as sensitive as cardiovascular disorders to psychosocial stressors, psychosocial influences on cancer incidence and outcome are present (discussions over this are ongoing [481, 482]).

7.8. Physical Functioning. Ability to function physically, that is, performing basic and instrumental activities of daily living such as toileting, bathing, shopping, and using a telephone, is a necessary factor for independent living. Persons who are depressed, unmotivated, or without hope are less likely to make attempts to maintain their physical functioning, particularly after experiencing a stroke or a fall that forces them into a rehabilitation program to regain or compensate for their losses. Several studies have examined the role that $\mathrm{R} / \mathrm{S}$ plays in helping people to maintain physical functioning as they grow older or regain functioning after an illness. We identified 61 quantitative studies that examined relationships between $\mathrm{R} / \mathrm{S}$ and disability level or level of functioning. Of those, $22(36 \%)$ reported better physical functioning among those who were more R/S, 14 (23\%) found worse physical functioning, and six studies reported mixed findings. Considering the 33 highest quality studies, 13 (39\%) reported significantly better physical functioning among those who were more R/S (including one study at a trend level) [483495], six (18\%) found worse functioning [496-501], and five studies (15\%) reported mixed results [82, 124, 502-504] (significant positive and negative associations, depending on $\mathrm{R} / \mathrm{S}$ characteristic). Almost all of these studies involve selfreported disability and many were cross-sectional, making it impossible to determine order of causation-that is, (1) does $\mathrm{R} / \mathrm{S}$ prevent the development of disability, (2) does disability prevent R/S activity, (3) does R/S promote disability, or (4) does disability cause people to turn to religion to cope with disability.

7.9. Self-Rated Health. There is more agreement across studies regarding the relationship between $\mathrm{R} / \mathrm{S}$ and self-rated health (SRH) than between R/S and physical functioning. While based on participants' subjective impression, selfrated health is strongly related to objective health, that is, future health, health services use, and mortality [505-507]. Might R/S, perhaps because it is related to greater optimism and hope, influence one's self-perceptions of health in a positive way? At least 50 studies have now examined the relationship between R/S and self-rated health. Of those, 29 (58\%) reported that R/S was related to better SRH, while five $(10 \%)$ found that it was related to worse SRH. Of the 37 methodologically most rigorous studies, 21 (57\%) reported significant positive relationships between $\mathrm{R} / \mathrm{S}$ and SRH $[503,508-527]$, whereas three (8\%) found the opposite [528-530].

7.10. Pain and Somatic Symptoms. On the one hand, pain and other distressing somatic symptoms can motivate people to seek solace in religion through activities such as prayer or Scripture study. Thus, $\mathrm{R} / \mathrm{S}$ is often turned to in order to cope with such symptoms. For example, in an early study of 382 adults with musculoskeletal complains, R/S coping was the most common strategy for dealing with pain and was considered the second most helpful in a long list of coping behaviors [531]. More recent research supports this earlier report [532]. On the other hand, R/S may somehow cause an increase in pain and somatic symptoms, perhaps by increasing concentration on negative symptoms or through the physical manifestations of hysteria, as claimed by Charcot in his copious writings around the turn of the 20th century [533].

We identified 56 studies that examined relationships between R/S and pain. Of those, 22 (39\%) reported inverse relationships between R/S and pain or found benefits from an R/S intervention, whereas 14 (25\%) indicated a positive relationship between R/S and greater pain levels (13 of 14 being cross-sectional). Of the 18 best studies, nine (50\%) reported inverse relationships (less pain among the more R/S [534] or reduced pain in response to a R/S intervention [535$542]$ ), while three $(20 \%)$ reported positive relationships (worse pain in the more R/S) [543-545]. Research suggests that meditation is particularly effective in reducing pain, although the effects are magnified when a religious word is used to focus attention $[546,547]$. No clinical trials, to my knowledge, have shown that meditation or other R/S interventions increase pain or somatic symptoms.

7.11. Mortality. The most impressive research on the relationship between $\mathrm{R} / \mathrm{S}$ and physical health is in the area of mortality. The cumulative effect of $R / S$, if it has any benefits to physical health, ought to reveal itself in an effect on mortality. The research suggests it does. At least 121 studies have examined relationships between R/S and mortality. Most of these are prospective cohort studies, where baseline R/S is assessed as a predictor of mortality during the observation period, controlling for confounders. Of those studies, 82 (68\%) found that greater R/S predicted significantly greater longevity (three at a trend level), whereas six studies (5\%) reported shorter longevity. Considering the 63 methodologically most rigorous studies (quality ratings of 8 or higher), 47 (75\%) found R/S predicting greater longevity (two at trend level) [548-566], whereas three (5\%) reported shorter longevity [567-569]. Another systematic review [570] and two meta-analyses $[571,572]$ have confirmed this relationship between R/S and longer survival. The effects have been particularly strong for frequency of attendance at religious services in these three reviews. Survival among frequent attendees was increased on average by $37 \%, 43 \%$, and $30 \%$ (mean effect being 37\% across these reviews). An increased survival of $37 \%$ is highly significant and equivalent to the 


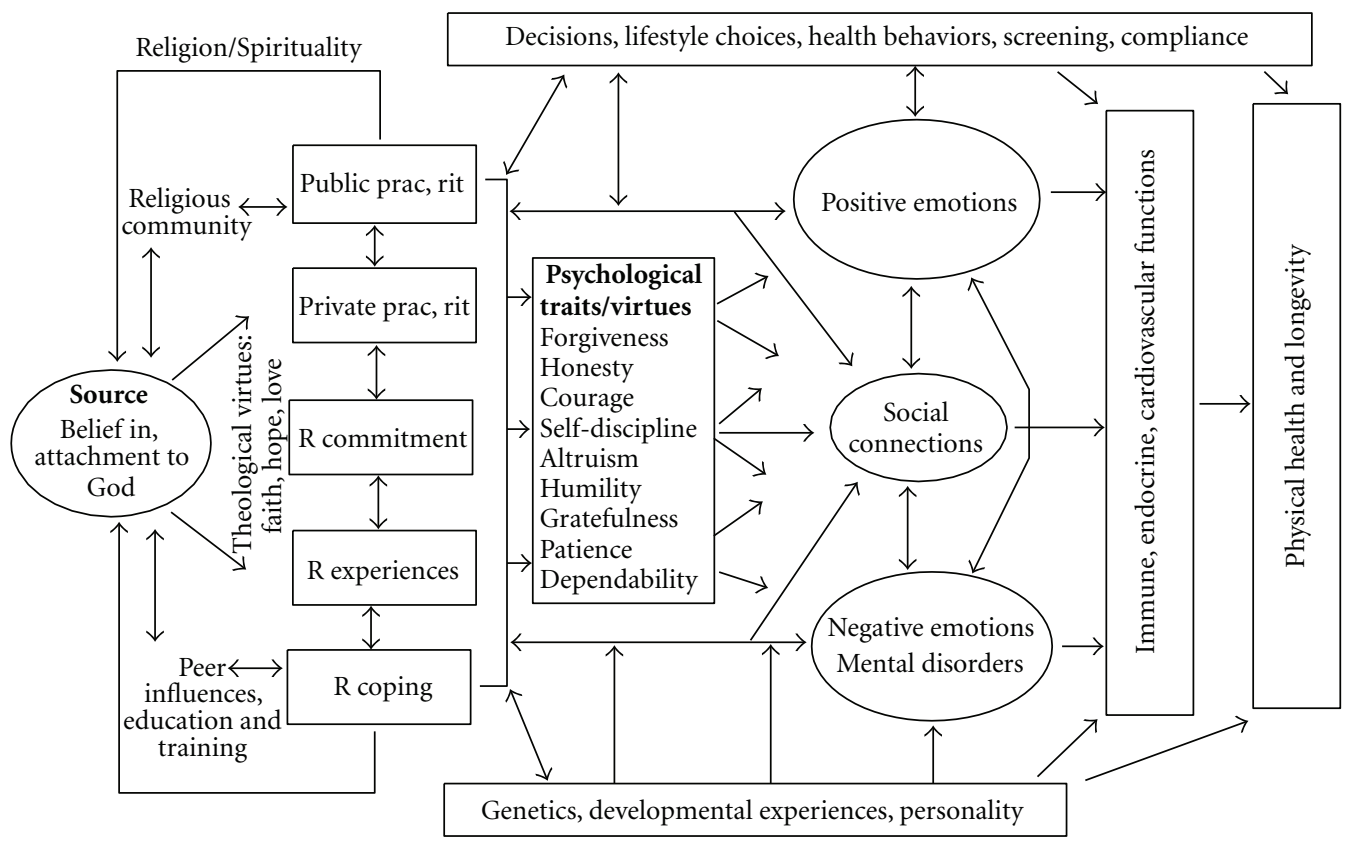

FIgURE 3: Theoretical model of causal pathways to physical health for Western monotheistic religions (Christianity, Islam, and Judaism). (Permission to reprint obtained. Original source: Koenig et al. [17]). For models based on Eastern religious traditions and the Secular Humanist tradition, see elsewhere (Koenig et al. [24]).

effects of cholesterol lowering drugs or exercise-based cardiac rehabilitation after myocardial infarction on survival [573].

\section{Explaining the Relationship: R/S and Physical Health}

How might R/S involvement influence physical health and longevity? There are at least three basic pathways: psychological, social, and behavioral (see Figure 3).

8.1. Psychological. As noted above, there is ample evidence that $\mathrm{R} / \mathrm{S}$ - because it facilitates coping and imbues negative events with meaning and purpose - is related to better mental health (less depression, lower stress, less anxiety, greater well-being, and more positive emotions). Furthermore, several randomized clinical trials have shown that R/S interventions improve mental health (at least in those who are $\mathrm{R} / \mathrm{S}$ ). There is also much evidence that poor mental health has adverse physiological consequences that worsen physical health and shorten the lifespan (see earlier references). Thus, it stands to reason that $\mathrm{R} / \mathrm{S}$ might influence physical health through psychological pathways.

8.2. Social. $\mathrm{R} / \mathrm{S}$ involvement is associated with greater social support, greater marital stability, less crime/delinquency, and greater social capital. R/S beliefs and doctrines encourage the development of human virtues such as honesty, courage, dependability, altruism, generosity, forgiveness, self-discipline, patience, humility, and other characteristics that promote social relationships. Participation in a R/S community not only provides supportive social connections and opportunities for altruism (through volunteering or other faithbased altruistic activities), but also increases the flow of health information that may increase disease screening and promote health maintenance. Social factors, in turn, are known to influence both mental health and physical health and predict greater longevity [574-576]. Again, if R/S boosts supportive social interactions and increases community trust and involvement, then it should ultimately influence physical health as well.

8.3. Health Behaviors. Finally, R/S promotes better health behaviors, and is associated with less alcohol and drug use, less cigarette smoking, more physical activity and exercise, better diet, and safer sexual practices in the overwhelming majority of studies that have examined these relationships. Living a healthier lifestyle will result in better physical health and greater longevity. Consider the following report that appeared on CNN (Cable Network News). On January 3, 2009, after the death of the Guinness Book of World Records' oldest person, Maria de Jesus age 115, next in line was Gertrude Baines from Los Angeles. Born to slaves near Atlanta in 1894, she was described at 114 years old as "spry," "cheerful," and "talkative." When she was 112 years old, Ms. Baines was asked by a CNN correspondent to explain why she thought she had lived so long. Her reply: "God. Ask Him. I took good care of myself, the way he wanted me to." Brief and to the point.

8.4. Other Pathways. There are many ways by which $\mathrm{R} / \mathrm{S}$ could have a positive influence on physical health, although the pathways above are probably the major ones. Genetic 
and developmental factors could also play a role in explaining these associations. There is some evidence that personality or temperament (which has genetic roots) influences whether or not a person becomes R/S. To what extent R/S persons are simply born healthier, however, is quite controversial. Note that more R/S persons are typically those with the least resources (minority groups, the poor, and the uneducated), both in terms of finances and access to healthcare resources. Karl Marx said that religion is the "opiate of the masses." Rather than being born healthier, then, the opposite is more likely to be true for R/S persons. R/S could actually be viewed as acting counter to an evolutionary force that is trying to weed genetically vulnerable people from the population. $\mathrm{R} / \mathrm{S}$ involvement is providing the weak with a powerful belief system and a supportive community that enables them to survive. For a more complete discussion of the role of genetic factors in the R/S-physical health relationship, see the Handbook [577].

Another important point needs to be made. Nowhere do I claim that supernatural mechanisms are responsible for the relationship between $\mathrm{R} / \mathrm{S}$ and health. The pathways by which $\mathrm{R} / \mathrm{S}$ influences physical health that researchers can study using the natural methods of science must be those that exist within nature - that is, psychological, social, behavioral, and genetic influences. Thus, this research says nothing about the existence of supernatural or transcendent forces (which is a matter of faith), but rather asks whether belief in such forces (and the behaviors that result from such beliefs) has an effect on health. There is every reason to think it does.

\section{Clinical Implications}

There are clinical implications from the research reviewed above that could influence the way health professionals treat patients in the hospital and clinic.

9.1. Rationale for Integrating Spirituality. There are many practical reasons why addressing spiritual issues in clinical practice is important. Here are eight reasons [578] (and these are not exhaustive).

First, many patients are R/S and have spiritual needs related to medical or psychiatric illness. Studies of medical and psychiatric patients and those with terminal illnesses report that the vast majority have such needs, and most of those needs currently go unmet $[579,580]$. Unmet spiritual needs, especially if they involve R/S struggles, can adversely affect health and may increase mortality independent of mental, physical, or social health [581].

Second, R/S influences the patient's ability to cope with illness. In some areas of the country, $90 \%$ of hospitalized patients use religion to enable them to cope with their illnesses and over $40 \%$ indicate it is their primary coping behavior [582]. Poor coping has adverse effects on medical outcomes, both in terms of lengthening hospital stay and increasing mortality [583].

Third, R/S beliefs affect patients' medical decisions, may conflict with medical treatments, and can influence compliance with those treatments. Studies have shown that
$\mathrm{R} / \mathrm{S}$ beliefs influence medical decisions among those with serious medical illness $[584,585]$ and especially among those with advanced cancer [586] or HIV/AIDs [587].

Fourth, physicians' own R/S beliefs often influence medical decisions they make and affect the type of care they offer to patients, including decisions about use of pain medications [588], abortion [589], vaccinations [590], and contraception [591]. Physician views about such matters and how they influence the physician's decisions, however, are usually not discussed with a patient.

Fifth, as noted earlier, R/S is associated with both mental and physical health and likely affects medical outcomes. If so, then health professionals need to know about such influences, just as they need to know if a person smokes cigarettes or uses alcohol or drugs. Those who provide health care to the patient need to be aware of all factors that influence health and health care.

Sixth, R/S influences the kind of support and care that patients receive once they return home. A supportive faith community may ensure that patients receive medical followup (by providing rides to doctors' offices) and comply with their medications. It is important to know whether this is the case or whether the patient will return to an apartment to live alone with little social interaction or support.

Seventh, research shows that failure to address patients' spiritual needs increases health care costs, especially toward the end of life [592]. This is a time when patients and families may demand medical care (often very expensive medical care) even when continued treatment is futile. For example, patients or families may be praying for a miracle. "Giving up" by withdrawing life support or agreeing to hospice care may be viewed as a lack of faith or lack of belief in the healing power of God. If health professionals do not take a spiritual history so that patients/families feel comfortable discussing such issues openly, then situations may go on indefinitely and consume huge amounts of medical resources.

Finally, standards set by the Joint Commission for the Accreditation of Hospital Organizations (JCAHO) and by Medicare (in the US) require that providers of health care show respect for patients' cultural and personal values, beliefs, and preferences (including religious or spiritual beliefs) [593]. This point was reinforced by a personal communication with Doreen Finn (dfinn@jointcommission .org), Senior Associate Director, who works under Mark Pelletier (mpelletier@jointcommission.org), Executive Director, JCAHO, Hospital Accreditation (January 6-12, 2012). If health professionals are unaware of those beliefs, they cannot show respect for them and adjust care accordingly.

9.2. How to Integrate Spirituality into Patient Care. What would I recommend in terms of addressing spiritual issues in clinical care?

First and foremost, health professionals should take a brief spiritual history. This should be done for all new patients on their first evaluation, especially if they have serious or chronic illnesses, and when a patient is admitted to a hospital, nursing home, home health agency, or other health care setting. The purpose is to learn about (1) the 
patient's religious background, (2) the role that R/S beliefs or practices play in coping with illness (or causing distress), (3) beliefs that may influence or conflict with decisions about medical care, (4) the patient's level of participation in a spiritual community and whether the community is supportive, and (5) any spiritual needs that might be present [594]. It is the health professional, not the chaplain, who is responsible for doing this two-minute "screening" evaluation. If spiritual needs are discovered, then the health professional would make a referral to pastoral care services so that the needs can be addressed. The spiritual history (and any spiritual needs addressed by pastoral services) should be documented in the medical record so that other health professionals will know that this has been done. Although notes need not be detailed, enough information should be recorded to communicate essential issues to other hospital staff.

Ideally, the physician, as head of the medical care team, should take the spiritual history. However, since only about $10 \%$ of physicians in the US "often or always" do so [595], the task often falls to the nurse or to the social worker. Although systematic research is lacking in this area, most nurses and social workers do not take a spiritual history either. Simply recording the patient's religious denomination and whether they want to see a chaplain, the procedure in most hospitals today, is NOT taking a spiritual history.

Second, R/S beliefs of patients uncovered during the spiritual history should always be respected. Even if beliefs conflict with the medical treatment plan or seem bizarre or pathological, the health professional should not challenge those beliefs (at least not initially), but rather take a neutral posture and ask the patient questions to obtain a better understanding of the beliefs. Challenging patients' $\mathrm{R} / \mathrm{S}$ beliefs is almost always followed by resistance from the patient, or quiet noncompliance with the medical plan. Instead, the health professional should consult a chaplain and either follow their advice or refer the patient to the chaplain to address the situation. If the health professional is knowledgeable about the patient's R/S beliefs and the beliefs appear generally healthy, however, it would be appropriate to actively support those beliefs and conform the healthcare being provided to accommodate the beliefs.

Third, most health professionals without clinical pastoral education do not have the skills or training to competently address patients' spiritual needs or provide advice about spiritual matters. Chaplains have extensive training on how to do this, which often involves years of education and experience addressing spiritual issues. They are the true experts in this area. For any but the most simple spiritual needs, then, patients should be referred to chaplains to address the problem.

Fourth, conducting a spiritual history or contemplating a spiritual intervention (supporting $\mathrm{R} / \mathrm{S}$ beliefs, praying with patients) should always be patient centered and patient desired. The health professional should never do anything related to $\mathrm{R} / \mathrm{S}$ that involves coercion. The patient must feel in control and free to reveal or not reveal information about their spiritual lives or to engage or not engage in spiritual practices (i.e., prayer, etc.). In most cases, health professionals should not ask patients if they would like to pray with them, but rather leave the initiative to the patient to request prayer. The health professional, however, may inform $\mathrm{R} / \mathrm{S}$ patients (based on the spiritual history) that they are open to praying with patients if that is what the patient wants. The patient is then free to initiate a request for prayer at a later time or future visit, should they desire prayer with the health professional. If the patient requests, then a short supportive prayer may be said aloud, but quietly, with the patient in a private setting. Before praying, however, the health professional should ask the patient what he or she wishes prayer for, recognizing that every patient will be different in this regard. Alternatively, the clinician may simply ask the patient to say the prayer and then quietly confirm it with an "amen" at the end.

Fifth, R/S beliefs of health professionals (or lack of belief) should not influence the decision to take a spiritual history, respect and support the R/S beliefs of patients, or make a referral to pastoral services. These activities should always be patient centered, not centered on the health professional. One of the most common barriers to addressing spiritual issues is health professionals' discomfort over discussing such issues. This often results from lack of personal R/S involvement and therefore lack of appreciation for the importance and value of doing so. Lack of comfort and understanding should be overcome by training and practice. Today, nearly $90 \%$ of medical schools (and many nursing schools) in the US include something about R/S in their curricula [596] and this is also true to a lesser extent in the United Kingdom [597] and Brazil [598]. Thus, spirituality and health is increasingly being addressed in medical and nursing training programs.

Sixth, health professionals should learn about the R/S beliefs and practices of different religious traditions that relate to healthcare, especially the faith traditions of patients they are likely to encounter in their particular country or region of the country. There are many such beliefs and practices that will have a direct impact on the type of care being provided, especially when patients are hospitalized, seriously ill or near death. A brief description of beliefs and practices for health professionals related to birth, contraception, diet, death, and organ donation is provided elsewhere [599].

Finally, if spiritual needs are identified and a chaplain referral is initiated, then the health professional making the referral is responsible for following up to ensure that the spiritual needs were adequately addressed by the chaplain. This is especially true given the impact that unmet spiritual needs are likely to have on both medical outcomes and healthcare costs. Given the short lengths of stay in today's modern hospital (often only 2-4 days), spiritual needs identified on admission are unlikely to be resolved by discharge. Therefore, a spiritual care discharge plan will need to be developed by the hospital social worker in consultation with the chaplain, which may involve (with the patient's written consent) contact with the patient's faith community to ensure that spiritual needs are addressed when the patient returns home. In this way, continuity of pastoral care will be ensured between hospital and community. 


\section{Conclusions}

Religious/spiritual beliefs and practices are commonly used by both medical and psychiatric patients to cope with illness and other stressful life changes. A large volume of research shows that people who are more R/S have better mental health and adapt more quickly to health problems compared to those who are less R/S. These possible benefits to mental health and well-being have physiological consequences that impact physical health, affect the risk of disease, and influence response to treatment. In this paper I have reviewed and summarized hundreds of quantitative original data-based research reports examining relationships between $\mathrm{R} / \mathrm{S}$ and health. These reports have been published in peer-reviewed journals in medicine, nursing, social work, rehabilitation, social sciences, counseling, psychology, psychiatry, public health, demography, economics, and religion. The majority of studies report significant relationships between R/S and better health. For details on these and many other studies in this area, and for suggestions on future research that is needed, I again refer the reader to the Handbook of Religion and Health [600].

The research findings, a desire to provide high-quality care, and simply common sense, all underscore the need to integrate spirituality into patient care. I have briefly reviewed reasons for inquiring about and addressing spiritual needs in clinical practice, described how to do so, and indicated boundaries across which health professionals should not cross. For more information on how to integrate spirituality into patient care, the reader is referred to the book, Spirituality in Patient Care [601]. The field of religion, spirituality, and health is growing rapidly, and I dare to say, is moving from the periphery into the mainstream of healthcare. All health professionals should be familiar with the research base described in this paper, know the reasons for integrating spirituality into patient care, and be able to do so in a sensible and sensitive way. At stake is the health and wellbeing of our patients and satisfaction that we as health care providers experience in delivering care that addresses the whole person—body, mind, and spirit.

\section{Conflict of Interests}

The author declares that he has no conflict of interests.

\section{Acknowledgment}

The support to write this paper was provided in part by the John Templeton Foundation.

\section{References}

[1] H. G. Koenig, D. E. King, and V. B. Carson, "A history of religion, medicine, and healthcare," in Handbook of Religion and Health, pp. 15-34, Oxford University Press, New York, NY, USA, 2nd edition, 2012.

[2] H. G. Koenig, Faith and Mental Health: Religious Resources For Healing, Templeton Press, Conshohocken, Pa, USA, 2005.
[3] See website: http://www.d.umn.edu/cla/faculty/tbacig/studproj/is3099/pplfrst/Untitled1.html, 2012.

[4] Restoration and 18th Century Studies in English, http://instruct.uwo.ca/english/234e/site/bckgrnds/maps/ lndnmpbedlam.html, 2012.

[5] L. Gamwell and N. Tomes, Madness in America: Cultural and Medical Perceptions of Mental Illness Before 1914, Cornell University Press, New York, NY, USA, 1995.

[6] T. Taubes, "'Healthy avenues of the mind': psychological theory building and the influence of religion during the era of moral treatment," American Journal of Psychiatry, vol. 155, no. 8, pp. 1001-1008, 1998.

[7] See website: http://friendshospital.com/about/timeline/, 2012.

[8] S. Freud, "Obsessive acts and religious practices," in Sigmund Freud: Collected Papers, J. Strachey, Ed., vol. 8, pp. 25-35, Basic Books, New York, NY, USA, 1907.

[9] S. Freud, "Psycho-analysis and religious origins," in Sigmund Freud: Collected Papers, J. Strachey, Ed., vol. 2, pp. 92-97, Basic Books, New York, 1919.

[10] S. Freud, "Future of an Illusion," in The Standard Edition of the Complete Psychological Works of Sigmund Freud, J. Strachey, Ed., pp. 1953-1973, Hogarth Press and the Institute of Psycho-Analysis, London, UK, 1927.

[11] S. Freud, "Moses and monotheism," in The Standard Edition of the Complete Psychological Works of Sigmund Freud, J. Strachey, Ed., pp. 1953-1973, Hogarth Press and the Institute of Psycho-Analysis, London, UK, 1939.

[12] D. B. Larson, S. B. Thielman, M. A. Greenwold et al., "Religious content in the DSM-III-R glossary of technical terms," American Journal of Psychiatry, vol. 150, no. 12, pp. 1884-1885, 1993.

[13] H. G. Koenig, "Religion and mental health: what are psychiatrists doing and should do?" Psychiatric Bulletin, vol. 32, no. 6, pp. 201-203, 2008.

[14] S. Dein, C. C. H. Cook, A. Powell, and S. Eagger, "Religion, spirituality and mental health," The Psychiatrist, vol. 34, pp. 63-64, 2010.

[15] R. Poole and C. C. H. Cook, "Praying with a patient constitutes a breach of professional boundaries in psychiatric practice," British Journal of Psychiatry, vol. 199, no. 2, pp. 9498, 2011.

[16] F. A. Curlin, R. E. Lawrence, S. Odell et al., "Religion, spirituality, and medicine: psychiatrists' and other physicians' differing observations, interpretations, and clinical approaches," American Journal of Psychiatry, vol. 164, no. 12, pp. 1825-1831, 2007.

[17] H. G. Koenig, D. E. King, and V. B. Carson, Handbook of Religion and Health, Oxford University Press, New York, NY, USA, 2nd edition, 2012.

[18] H. G. Koenig, "Concerns about measuring "spirituality" in research," Journal of Nervous and Mental Disease, vol. 196, no. 5, pp. 349-355, 2008.

[19] M. T. Tsuang and J. C. Simpson, "Commentary on Koenig (2008): 'Concerns about measuring "Spirituality" in research," Journal of Nervous and Mental Disease, vol. 196, no. 8, pp. 647-649, 2008.

[20] H. G. Koenig, "Definitions," in Spirituality and Health Research: Methods, Measurement, Statistics, and Resources, pp. 193-206, Templeton Foundation Press, Philadelphia, Pa, USA, 2011.

[21] H. G. Koenig, D. E. King, and V. B. Carson, Handbook of Religion and Health, Oxford University Press, New York, NY, USA, 2nd edition, 2012. 
[22] H. G. Koenig, D. E. King, and V. B. Carson, Handbook of Religion and Health, Oxford University Press, New York, NY, USA, 2nd edition, 2012.

[23] H. G. Koenig, M. E. McCullough, and D. B. Larson, Handbook of Religion and Health, Oxford University Press, New York, NY, USA, 1st edition, 2001.

[24] H. G. Koenig, D. E. King, and V. B. Carson, Handbook of Religion and Health, Oxford University Press, New York, NY, USA, 2nd edition, 2012.

[25] H. M. Cooper, The IntegrAted ReseArch Review: A SystemAtic ApproAch, vol. 2, Sage Publications, Beverly Hills, Calif, USA, 1984.

[26] J. R. Landis and G. G. Koch, "The measurement of observer agreement for categorical data," Biometrics, vol. 33, no. 1, pp. 159-174, 1977.

[27] H. G. Koenig, M. E. McCullough, and D. B. Larson, Handbook of Religion and Health, Oxford University Press, New York, NY, USA, 1st edition, 2001.

[28] H. G. Koenig, "Religious beliefs and practices of hospitalized medically ill older adults," International Journal of Geriatric Psychiatry, vol. 13, pp. 213-224, 1998.

[29] K. I. Pargament, H. G. Koenig, N. Tarakeshwar, and J. Hahn, "Religious coping methods as predictors of psychological, physical and spiritual outcomes among medically ill elderly patients: a two-year longitudinal study," Journal of Health Psychology, vol. 9, no. 6, pp. 713-730, 2004.

[30] A. Büssing, A. Michalsen, H. J. Balzat et al., "Are spirituality and religiosity resources for patients with chronic pain conditions?" Pain Medicine, vol. 10, no. 2, pp. 327-339, 2009.

[31] A. P. Tix and P. A. Frazier, "The use of religious coping during stressful life events: main effects, moderation, and mediation," Journal of Consulting and Clinical Psychology, vol. 66, no. 2, pp. 411-422, 1998.

[32] A. Zaldívar and J. Smolowitz, "Perceptions of the importance placed on religion and folk medicine by non-MexicanAmerican Hispanic adults with diabetes.," The Diabetes educator, vol. 20, no. 4, pp. 303-306, 1994.

[33] G. Fitchett, P. E. Murphy, J. Kim, J. L. Gibbons, J. R. Cameron, and J. A. Davis, "Religious struggle: prevalence, correlates and mental health risks in diabetic, congestive heart failure, and oncology patients," International Journal of Psychiatry in Medicine, vol. 34, no. 2, pp. 179-196, 2004.

[34] S. C. Sodergren, M. E. Hyland, A. Crawford, and M. R. Partridge, "Positivity in illness: self-delusion or existential," British Journal of Health Psychology, vol. 9, no. 2, pp. 163174, 2004.

[35] S. M. Yoshimoto, S. Ghorbani, J. M. Baer et al., "Religious coping and problem-solving by couples faced with prostate cancer," European Journal of Cancer Care, vol. 15, no. 5, pp. 481-488, 2006.

[36] B. Shaw, J. Y. Han, E. Kim et al., "Effects of prayer and religious expression within computer support groups on women with breast cancer," Psycho-Oncology, vol. 16, no. 7, pp. 676-687, 2007.

[37] M. Cooper-Effa, W. Blount, N. Kaslow, R. Rothenberg, and J. Eckman, "Role of spirituality in patients with sickle cell disease," Journal of the American Board of Family Practice, vol. 14, no. 2, pp. 116-122, 2001.

[38] J. W. Hughes, A. Tomlinson, J. A. Blumenthal, J. Davidson, M. H. Sketch, and L. L. Watkins, "Social support and religiosity as coping strategies for anxiety in hospitalized cardiac patients," Annals of Behavioral Medicine, vol. 28, no. 3, pp. 179-185, 2004.
[39] A. L. Ai, C. L. Park, Bu Huang, W. Rodgers, and T. N. Tice, "Psychosocial mediation of religious coping styles: a study of short-term psychological distress following cardiac surgery," Personality and Social Psychology Bulletin, vol. 33, no. 6, pp. 867-882, 2007.

[40] G. Heydecke, L. A. Tedesco, C. Kowalski, and M. R. Inglehart, "Complete dentures and oral health-related quality of lifedo coping styles matter?" Community Dentistry and Oral Epidemiology, vol. 32, no. 4, pp. 297-306, 2004.

[41] G. Magyar-Russell, P. Fosarelli, H. Taylor, and D. Finkelstein, "Ophthalmology patients' religious and spiritual beliefs: an opportunity to build trust in the patient-physician relationship," Archives of Ophthalmology, vol. 126, no. 9, pp. 12621265, 2008

[42] S. Giaquinto, C. Spiridigliozzi, and B. Caracciolo, "Can faith protect from emotional distress after stroke?” Stroke, vol. 38, no. 3, pp. 993-997, 2007.

[43] S. Cotton, C. M. Puchalski, S. N. Sherman et al., "Spirituality and religion in patients with HIV/AIDS," Journal of General Internal Medicine, vol. 21, no. 5, pp. S5-S13, 2006.

[44] S. Rinaldi, M. Ghisi, L. Iaccarino et al., "Influence of coping skills on health-related quality of life in patients with systemic lupus erythematosus," Arthritis Care and Research, vol. 55, no. 3, pp. 427-433, 2006.

[45] L. Kuttner, C. T. Chambers, J. Hardial, D. M. Israel, K. Jacobson, and K. Evans, "A randomized trial of yoga for adolescents with irritable bowel syndrome," Pain Research and Management, vol. 11, no. 4, pp. 217-223, 2006.

[46] A. F. Abraído-Lanza, E. Vásquez, and S. E. Echeverría, "En las Manos de Dios [in God's Hands]: religious and other forms of coping among Latinos with arthritis," Journal of Consulting and Clinical Psychology, vol. 72, no. 1, pp. 91-102, 2004.

[47] P. V. Rabins, M. D. Fitting, J. Eastham, and J. Zabora, "Emotional adaptation over time in care-givers for chronically ill elderly people," Age and Ageing, vol. 19, no. 3, pp. 185-190, 1990.

[48] S. Folkman, M. A. Chesney, M. Cooke, A. Boccellari, and L. Collette, "Caregiver burden in HIV-positive and HIVnegative partners of men with AIDS," Journal of Consulting and Clinical Psychology, vol. 62, no. 4, pp. 746-756, 1994.

[49] R. S. Hebert, Q. Dang, and R. Schulz, "Religious beliefs and practices are associated with better mental health in family caregivers of patients with dementia: findings from the reach study," American Journal of Geriatric Psychiatry, vol. 15, no. 4, pp. 292-300, 2007.

[50] L. Tepper, S. A. Rogers, E. M. Coleman, and H. N. Malony, "The prevalence of religious coping among persons with persistent mental illness," Psychiatric Services, vol. 52, no. 5, pp. 660-665, 2001.

[51] H. B. Bosworth, K. S. Park, D. R. McQuoid, J. C. Hays, and D. C. Steffens, "The impact of religious practice and religious coping on geriatric depression," International Journal of Geriatric Psychiatry, vol. 18, no. 10, pp. 905-914, 2003.

[52] S. A. Murphy, L. C. Johnson, and J. Lohan, "Finding meaning in a child's violent death: a five-year prospective analysis of parents' personal narratives and empirical data," Death Studies, vol. 27, no. 5, pp. 381-404, 2003.

[53] S. L. Brown, R. M. Nesse, J. S. House, and R. L. Utz, "Religion and emotional compensation: results from a prospective study of widowhood," Personality and Social Psychology Bulletin, vol. 30, no. 9, pp. 1165-1174, 2004.

[54] E. L. Idler, S. V. Kasl, and J. C. Hays, "Patterns of religious practice and belief in the last year of life," Journals of Gerontology B, vol. 56, no. 6, pp. S326-S334, 2001. 
[55] E. J. Emanuel, D. L. Fairclough, P. Wolfe, and L. L. Emanuel, "Talking with terminally ill patients and their caregivers about death, dying, and bereavement: is it stressful? Is it helpful?" Archives of Internal Medicine, vol. 164, no. 18, pp. 1999-2004, 2004.

[56] H. G. Koenig, H. J. Cohen, D. G. Blazer et al., "Religious coping and depression among elderly, hospitalized medically ill men," American Journal of Psychiatry, vol. 149, no. 12, pp. 1693-1700, 1992.

[57] R. W. Larson, D. M. Hansen, and G. Moneta, "Differing profiles of developmental experiences across types of organized youth activities," Developmental Psychology, vol. 42, no. 5, pp. 849-863, 2006.

[58] J. Pienaar, S. Rothmann, and F. J. R. Van Devijver, “Occupational stress, personality traits, coping strategies, and suicide ideation in the South African police service," Criminal Justice and Behavior, vol. 34, no. 2, pp. 246-258, 2007.

[59] B. W. Smith, "Coping as a predictor of outcomes following the 1993 midwest flood," Journal of Social Behavior and Personality, vol. 11, no. 2, pp. 225-239, 1996.

[60] M. Hollifield, C. Hewage, C. N. Gunawardena, P. Kodituwakku, K. Bopagoda, and K. Weerarathnege, "Symptoms and coping in Sri Lanka 20-21 months after the 2004 tsunami," British Journal of Psychiatry, vol. 192, no. 1, pp. 3944, 2008.

[61] K. I. Pargament, K. Ishler, E. Dubow et al., "Methods of religious coping with the Gulf War: cross-sectional and longitudinal analyses," Journal For the Scientific Study of Religion, vol. 33, no. 4, pp. 347-361, 1994.

[62] W. F. Scholte, M. Olff, P. Ventevogel et al., "Mental health symptoms following war and repression in Eastern Afghanistan," Journal of the American Medical Association, vol. 292, no. 5, pp. 585-593, 2004.

[63] M. A. Schuster, B. D. Stein, L. H. Jaycox et al., "A national survey of stress reactions after the September 11, 2001, terrorist attacks," New England Journal of Medicine, vol. 345, no. 20, pp. 1507-1512, 2001.

[64] C. G. Ellison and R. J. Taylor, "Turning to prayer: social and situational antecedents of religious coping among African Americans," Review of Religious Research, vol. 38, no. 2, pp. 111-131, 1996.

[65] K. I. Pargament, H. G. Koenig, and L. M. Perez, "A comprehensive measure of religious coping: development and initial validation of the RCOPE," Journal of Clinical Psychology, vol. 56, no. 4, pp. 519-543, 1999.

[66] J. Nooney and E. Woodrum, "Religious coping and churchbased social support as predictors of mental health outcomes: testing a conceptual model," Journal For the Scientific Study of Religion, vol. 41, no. 2, pp. 359-368, 2002.

[67] H. G. Koenig, J. N. Kvale, and C. Ferrel, "Religion and wellbeing in later life," Gerontologist, vol. 28, no. 1, pp. 18-28, 1988.

[68] F. K. Willits and D. M. Crider, "Religion and well-being: men and women in the middle years," Review of Religious Research, vol. 29, no. 3, pp. 281-294, 1988.

[69] J. S. Levin, L. M. Chatters, and R. J. Taylor, "Religious effects on health status and life satisfaction among Black Americans," Journals of Gerontology B, vol. 50, no. 3, pp. S154-S163, 1995.

[70] J. S. Levin, K. S. Markides, and L. A. Ray, "Religious attendance and psychological well-being in Mexican Americans: a panel analysis of three-generations data," Gerontologist, vol. 36, no. 4, pp. 454-463, 1996.
[71] C. G. Ellison, J. D. Boardman, D. R. Williams, and J. S. Jackson, "Religious involvement, stress, and mental health: findings from the 1995 Detroit area study," Social Forces, vol. 80, no. 1, pp. 215-249, 2001.

[72] N. Krause, "Religious meaning and subjective well-being in late life," Journals of Gerontology B, vol. 58, no. 3, pp. S160S170, 2003.

[73] N. Krause, "Common facets of religion, unique facets of religion, and life satisfaction among older African Americans," Journals of Gerontology B, vol. 59, no. 2, pp. S109-S117, 2004.

[74] K. V. Greene and B. J. Yoon, "Religiosity, economics and life satisfaction," Review of Social Economy, vol. 62, no. 2, pp. 245-273, 2004.

[75] O. Lelkes, "Tasting freedom: happiness, religion and economic transition," Journal of Economic Behavior and Organization, vol. 59, no. 2, pp. 173-194, 2006.

[76] S. Uppal, "Impact of the timing, type and severity of disability on the subjective well-being of individuals with disabilities," Social Science and Medicine, vol. 63, no. 2, pp. 525-539, 2006.

[77] S. Crabtree, B. Pelham, and World Gallup Poll., 2009, Religion Provides Emotional Boost to World's Poor, Gallup.

[78] P. Dalgalarrondo, L. Marín-León, J. N. Botega, M. B. De Azevedo Barros, and H. Bosco de Oliveira, "Religious affiliation and psychiatric morbidity in Brazil: higher rates among evangelicals and spiritists," International Journal of Social Psychiatry, vol. 54, no. 6, pp. 562-574, 2008.

[79] S. Sethi and M. E. P. Seligman, "The hope of fundamentalists," Psychological Science, vol. 5, pp. 58-59, 1994.

[80] P. E. Murphy, J. W. Ciarrocchi, R. L. Piedmont, S. Cheston, M. Peyrot, and G. Fitchett, "The relation of religious belief and practices, depression, and hopelessness in persons with clinical depression," Journal of Consulting and Clinical Psychology, vol. 68, no. 6, pp. 1102-1106, 2000.

[81] A. L. Ai, C. L. Park, Bu Huang, W. Rodgers, and T. N. Tice, "Psychosocial mediation of religious coping styles: a study of short-term psychological distress following cardiac surgery," Personality and Social Psychology Bulletin, vol. 33, no. 6, pp. 867-882, 2007.

[82] E. L. Idler and S. V. Kasl, "Religion among disabled and nondisabled persons I: cross-sectional patterns in health practices, social activities, and well-being," Journals of Gerontology B, vol. 52, no. 6, pp. S294-S305, 1997.

[83] N. Krause, "Church-based social support and health in old age: exploring variations by race," Journals of Gerontology B, vol. 57, no. 6, pp. S332-S347, 2002.

[84] A. L. Ai, C. Peterson, S. F. Bolling, and H. Koenig, "Private prayer and optimism in middle-aged and older patients awaiting cardiac surgery," Gerontologist, vol. 42, no. 1, pp. 70$81,2002$.

[85] N. Krause, "Religious doubt and psychological well-being: a longitudinal investigation," Review of Religious Research, vol. 47, no. 3, pp. 287-302, 2006.

[86] L. J. Francis, "The relationship between bible reading and purpose in life among 13-15-year-olds," Mental Health, Religion and Culture, vol. 3, no. 1, pp. 33-36, 2000.

[87] A. Skrabski, M. Kopp, S. Rózsa, J. Réthelyi, and R. H. Rahe, "Life meaning: an important correlate of health in the Hungarian population," International Journal of Behavioral Medicine, vol. 12, no. 2, pp. 78-85, 2005.

[88] N. Krause, "Meaning in life and mortality," Journal of Gerontology B, supplement 64, no. 4, pp. S517-S527, 2009. 
[89] N. Krause, "God-mediated control and change in self-rated health," International Journal for the Psychology of Religion, vol. 20, no. 4, pp. 267-287, 2010.

[90] W. Watters, Deadly Doctrine: Health, Illness, and Christian God-Talk, Prometheus Books, Buffalo, NY, USA, 1992.

[91] C. G. Ellison, "Religious involvement and self-perception among Black Americans," Social Forces, vol. 71, pp. 10271055, 1993.

[92] N. Krause and T. Van Tran, "Stress and religious involvement among older Blacks," Journals of Gerontology, vol. 44, no. 1, pp. S4-S13, 1989.

[93] N. Krause, "Stress, religiosity, and psychological well-being among older blacks," Journal of Aging and Health, vol. 4, no. 3, pp. 412-439, 1992.

[94] N. Krause, "Religiosity and self-esteem among older adults," Journals of Gerontology B, vol. 50, no. 5, pp. P236-P246, 1995.

[95] N. Krause, "Religious meaning and subjective well-being in late life," Journals of Gerontology B, vol. 58, no. 3, pp. S160S170, 2003.

[96] T. N. Le, W. Tov, and J. Taylor, "Religiousness and depressive symptoms in five ethnic adolescent groups," International Journal for the Psychology of Religion, vol. 17, no. 3, pp. 209232, 2007.

[97] T. D. Hill, A. M. Burdette, M. Regnerus, and R. J. Angel, "Religious involvement and attitudes toward parenting among low-income Urban women," Journal of Family Issues, vol. 29, no. 7, pp. 882-900, 2008.

[98] K. M. Trevino, K. I. Pargament, S. Cotton et al., "Religious coping and physiological, psychological, social, and spiritual outcomes in patients with HIV/AIDS: cross-sectional and longitudinal findings," AIDS and Behavior, vol. 14, no. 2, pp. 379-389, 2010.

[99] C. G. Ellison and R. J. Taylor, "Turning to prayer: social and situational antecedents of religious coping among African Americans," Review of Religious Research, vol. 38, no. 2, pp. 111-131, 1996.

[100] K. Miller, B. Yost, S. Flaherty et al., "Health status, health conditions, and health behaviors among Amish women. Results from the Central Pennsylvania Women's Health Study (CePAWHS)," Women's Health Issues, vol. 17, no. 3, pp. 162$171,2007$.

[101] V. R. Kivett, "Religious motivation in middle age: correlates and implications," Journals of Gerontology, vol. 34, no. 1, pp. 106-115, 1979.

[102] F. D. Wolinsky and T. E. Stump, "Age and the sense of control among older adults," Journals of Gerontology B, vol. 51, no. 4, pp. S217-S220, 1996.

[103] S. Schieman, K. Van Gundy, and J. Taylor, "The relationship between age and depressive symptoms: a test of competing explanatory and suppression influences," Journal of Aging and Health, vol. 14, no. 2, pp. 260-285, 2002.

[104] K. L. Fiori, E. E. Brown, K. S. Cortina, and T. C. Antonucci, "Locus of control as a mediator of the relationship between religiosity and life satisfaction: Age, race, and gender differences," Mental Health, Religion and Culture, vol. 9, no. 3, pp. 239-263, 2006.

[105] B. A. Shaw and N. Krause, "Exploring race variations in aging and personal control," Journals of Gerontology B, vol. 56, supplement 2, pp. S119-S124, 2001.

[106] F. D. Wolinsky, K. W. Wyrwich, K. Kroenke, A. N. Babu, and W. M. Tierney, "9-11, Personal stress, mental health, and sense of control among older adults," Journals of Gerontology B, vol. 58, supplement 3, pp. S146-S150, 2003.
[107] M. A. Bruce and M. C. Thornton, "It's my world? Exploring black and white perceptions of personal control," Sociological Quarterly, vol. 45, no. 3, pp. 597-612, 2004.

[108] L. D. Nelson and R. R. Dynes, "The impact of devotionalism and attendance on ordinary and emergency helping behavior," Journal For the Scientific Study of Religion, vol. 15, no. 1, pp. 47-59, 1976.

[109] M. A. Okun, "Predictors of volunteer status in a retirement community," International Journal of Aging and Human Development, vol. 36, no. 1, pp. 57-74, 1993.

[110] A. H. S. Harris and C. E. Thoresen, "Volunteering is associated with delayed mortality in older people: analysis of the longitudinal study of aging," Journal of Health Psychology, vol. 10, no. 6, pp. 739-752, 2005.

[111] V. Saroglou, I. Pichon, L. Trompette, M. Verschueren, and R. Dernelle, "Prosocial behavior and religion: new evidence based on projective measures and peer ratings," Journal for the Scientific Study of Religion, vol. 44, no. 3, pp. 323-348, 2005.

[112] J. Warburton and C. Stirling, "Factors affecting volunteering among older Rural and city dwelling adults in Australia," Educational Gerontology, vol. 33, no. 1, pp. 23-43, 2007.

[113] E. H. Ecklund and J. Z. Park, "Religious diversity and community volunteerism among Asian Americans," Journal for the Scientific Study of Religion, vol. 46, no. 2, pp. 233-244, 2007.

[114] Y. W. Yew, S. M. Saw, J. C. H. Pan et al., "Knowledge and beliefs on corneal donation in Singapore adults," British Journal of Ophthalmology, vol. 89, no. 7, pp. 835-840, 2005.

[115] S. E. Morgan, "Many facets of reluctance: African Americans and the decision (not) to donate organs," Journal of the National Medical Association, vol. 98, no. 5, pp. 695-703, 2006.

[116] R. L. Gorsuch and J. Y. Hao, "Forgiveness: an exploratory factor analysis and its relationship to religious variables," Review of Religious Research, vol. 34, no. 4, pp. 333-347, 1993.

[117] N. Krause and C. G. Ellison, "Forgiveness by God, forgiveness of others, and psychological well-being in late life," Journal For the Scientific Study of Religion, vol. 42, no. 1, pp. 77-93, 2003.

[118] L. L. Toussaint and D. R. Williams, "National survey results for Protestant, Catholic, and nonreligious experiences of seeking forgiveness and of forgiveness of self, of others, and by God," Journal of Psychology and Christianity, vol. 27, no. 2, pp. 120-130, 2008.

[119] N. Krause, "Church-based emotional support and selfforgiveness in late life," Review of Religious Research, vol. 52, no. 1, pp. 72-89, 2010.

[120] L. L. Toussaint, J. C. Marschall, and D. R. Williams, "Prospective associations between religiousness/spirituality and depression and mediating effeccts of forgiveness in a nationally representative sample of United States adults," Depression Research and Treatment, vol. 2012, Article ID 267820, 10 pages, 2012.

[121] R. A. Emmons and T. T. Kneezel, "Giving thanks: spiritual and religious correlates of gratitude," Journal of Psychology and Christianity, vol. 24, no. 2, pp. 140-148, 2005.

[122] N. Krause, "Religious involvement, gratitude, and change in depressive symptoms over time," International Journal for the Psychology of Religion, vol. 19, no. 3, pp. 155-172, 2009.

[123] P. R. Steffen and K. S. Masters, "Does compassion mediate the intrinsic religion-health relationship?" Annals of Behavioral Medicine, vol. 30, no. 3, pp. 217-224, 2005. 
[124] E. L. Idler and S. V. Kasl, "Religion, disability, depression, and the timing of death," American Journal of Sociology, vol. 97, no. 4, pp. 1052-1079, 1992.

[125] G. J. Kennedy, H. R. Kelman, C. Thomas, and J. Chen, "The relation of religious preference and practice to depressive symptoms among 1,855 older adults," Journals of Gerontology, vol. 51, no. 6, pp. P301-P308, 1996.

[126] H. G. Koenig, H. J. Cohen, D. G. Blazer et al., "Religious coping and depression among elderly, hospitalized medically ill men," American Journal of Psychiatry, vol. 149, no. 12, pp. 1693-1700, 1992.

[127] H. G. Koenig, L. K. George, and B. L. Peterson, "Religiosity and remission of depression in medically ill oder patients," American Journal of Psychiatry, vol. 155, no. 4, pp. 536-542, 1998.

[128] M. A. Musick, H. G. Koenig, J. C. Hays, and H. J. Cohen, "Religious activity and depression among communitydwelling elderly persons with cancer: The moderating effect of race," Journals of Gerontology, vol. 53, no. 4, pp. S218-S227, 1998.

[129] L. R. Propst, R. Ostrom, P. Watkins, T. Dean, and D. Mashburn, "Comparative efficacy of religious and nonreligious cognitive-behavioral therapy for the treatment of clinical depression in religious individuals," Journal of Consulting and Clinical Psychology, vol. 60, no. 1, pp. 94-103, 1992.

[130] W. J. Strawbridge, S. J. Shema, R. D. Cohen, and G. A. Kaplan, "Religious attendance increases survival by improving and maintaining Good health behaviors, mental health, and social relationships," Annals of Behavioral Medicine, vol. 23, no. 1 , pp. $68-74,2001$.

[131] H. G. Koenig, "Religion and remission of depression in medical inpatients with heart failure/pulmonary disease," Journal of Nervous and Mental Disease, vol. 195, no. 5, pp. 389-395, 2007.

[132] B. W. Van Voorhees, D. Paunesku, S. A. Kuwabara et al., "Protective and vulnerability factors predicting new-onset depressive episode in a representative of U.S. adolescents," Journal of Adolescent Health, vol. 42, no. 6, pp. 605-616, 2008.

[133] C. G. Ellison and K. J. Flannelly, "Religious involvement and risk of major depression in a prospective nationwide study of African American adults," Journal of Nervous and Mental Disease, vol. 197, no. 8, pp. 568-573, 2009.

[134] N. Krause, "Religious involvement, gratitude, and change in depressive symptoms over time," International Journal for the Psychology of Religion, vol. 19, no. 3, pp. 155-172, 2009.

[135] V. Payman, K. George, and B. Ryburn, "Religiosity of depressed elderly inpatients," International Journal of Geriatric Psychiatry, vol. 23, no. 1, pp. 16-21, 2008.

[136] D. Spiegel, J. R. Bloom, and E. Gottheil, "Family environment as a predictor of adjustment to metastatic breast carcinoma," Journal of Psychosocial Oncology, vol. 1, no. 1, pp. 33-44, 1983.

[137] K. I. Pargament, H. G. Koenig, N. Tarakeshwar, and J. Hahn, "Religious coping methods as predictors of psychological, physical and spiritual outcomes among medically ill elderly patients: a two-year longitudinal study," Journal of Health Psychology, vol. 9, no. 6, pp. 713-730, 2004.

[138] A. W. Braam, P. Delespaul, A. T. Beekman et al., "National context of healthcare, economy and religion, and the association between disability and depressive symptoms in older Europeans: results from the EURODEP concerted action," European Journal of Ageing, vol. 1, no. 1, pp. 26-36, 2004.
[139] L. Wijngaards-De Meij, M. Stroebe, H. Schut et al., "Couples at risk following the death of their child: Predictors of grief versus depression," Journal of Consulting and Clinical Psychology, vol. 73, no. 4, pp. 617-623, 2005.

[140] Z. Solomon, M. Gelkopf, and A. Bleich, "Is terror genderblind? Gender differences in reaction to terror events," Social Psychiatry and Psychiatric Epidemiology, vol. 40, no. 12, pp. 947-954, 2005.

[141] A. H. Eliassen, J. Taylor, and D. A. Lloyd, "Subjective religiosity and depression in the transition to adulthood," Journal for the Scientific Study of Religion, vol. 44, no. 2, pp. 187-199, 2005.

[142] J. E. Bormann, A. L. Gifford, M. Shively et al., "Effects of spiritual mantram repetition on HIV outcomes: a randomized controlled trial," Journal of Behavioral Medicine, vol. 29, no. 4, pp. 359-376, 2006.

[143] M. R. Benjamins, "Predictors of preventive health care use among middle-aged and older adults in Mexico: the role of religion," Journal of Cross-Cultural Gerontology, vol. 22, no. 2, pp. 221-234, 2007.

[144] K. J. Branco, "Religious activities, strength from faith, and social functioning among African American and white nursing home residents," Journal of Religion, Spirituality and Aging, vol. 19, no. 4, pp. 3-20, 2007.

[145] A. W. Braam, D. J. H. Deeg, J. L. Poppelaars, A. T. F. Beekman, and W. Van Tilburg, "Prayer and depressive symptoms in a period of secularization: patterns among older adults in the Netherlands," American Journal of Geriatric Psychiatry, vol. 15, no. 4, pp. 273-281, 2007.

[146] G. Andersson, "Chronic pain and praying to a higher power: useful or useless?" Journal of Religion and Health, vol. 47, no. 2, pp. 176-187, 2008.

[147] W. R. Miller, A. Forcehimes, M. J. O'Leary, and M. D. LaNoue, "Spiritual direction in addiction treatment: two clinical trials," Journal of Substance Abuse Treatment, vol. 35, no. 4, pp. 434-442, 2008.

[148] J. Maselko and S. Buka, "Religious activity and lifetime prevalence of psychiatric disorder," Social Psychiatry and Psychiatric Epidemiology, vol. 43, no. 1, pp. 18-24, 2008.

[149] J. E. Bormann, A. L. Gifford, M. Shively et al., "Effects of spiritual mantram repetition on HIV outcomes: a randomized controlled trial," Journal of Behavioral Medicine, vol. 29, no. 4, pp. 359-376, 2006.

[150] W. R. Miller, A. Forcehimes, M. J. O'Leary, and M. D. LaNoue, "Spiritual direction in addiction treatment: two clinical trials," Journal of Substance Abuse Treatment, vol. 35, no. 4, pp. 434-442, 2008.

[151] T. B. Smith, M. E. McCullough, and J. Poll, "Religiousness and depression: evidence for a main effect and the moderating influence of stressful life events," Psychological Bulletin, vol. 129, no. 4, pp. 614-636, 2003.

[152] L. Miller, P. Wickramaratne, M. J. Gameroff, M. Sage, C. E. Tenke, and M. M. Weissman, "Religiosity and major depression in adults at high risk: a ten-year prospective study," American Journal of Psychiatry, vol. 169, no. 1, pp. 8994, 2012.

[153] S. Kasen, P. Wickramaratne, and M. J. Gameroff, "Religiosity and resilience in persons at high risk for major depression," Psychological Medicine, vol. 42, no. 3, pp. 509-519, 2012.

[154] L. Miller, R. Bansai, P. Wickramaratne, X. Hao, C. E. Tenke, and M. M. Weissman, "Neuroanatomical correlates of religiosity and spirituality in adults at high and low familial risk for depression' (forthcoming)". 
[155] E. S. Paykel, J. K. Myers, J. J. Lindenthal, and J. Tanner, "Suicidal feelings in the general population: a prevalence study," British Journal of Psychiatry, vol. 124, no. 5, pp. 460469, 1974.

[156] B. K. Singh, J. S. Williams, and B. J. Ryther, "Public approval of suicide: a situational analysis," Suicide and LifeThreatening Behavior, vol. 16, no. 4, pp. 409-418, 1986.

[157] K. R. Truett, L. J. Eaves, J. M. Meyer, A. C. Heath, and N. G. Martin, "Religion and education as mediators of attitudes: a multivariate analysis," Behavior Genetics, vol. 22, no. 1, pp. 43-62, 1992.

[158] S. Stack and I. Wasserman, "The effect of marriage, family, and religious ties on African American suicide ideology," Journal of Marriage and the Family, vol. 57, no. 1, pp. 215222, 1995.

[159] C. Krull and F. Trovato, "The quiet revolution and the sex differential in Quebec's suicide rates: 1931-1986," Social Forces, vol. 72, no. 4, pp. 1121-1147, 1994.

[160] M. Siegrist, "Church attendance, denomination, and suicide ideology," Journal of Social Psychology, vol. 136, no. 5, pp. 559-566, 1996.

[161] J. Neeleman, D. Halpern, D. Leon, and G. Lewis, “Tolerance of suicide, religion and suicide rates: an ecological and individual study in 19 Western countries," Psychological Medicine, vol. 27, no. 5, pp. 1165-1171, 1997.

[162] C. G. Ellison, J. A. Burr, and P. L. Mccall, "Religious homogeneity and metropolitan suicide rates," Social Forces, vol. 76, no. 1, pp. 273-299, 1997.

[163] J. Neeleman, S. Wessely, and G. Lewis, "Suicide acceptability in African- and white Americans: the role of religion," Journal of Nervous and Mental Disease, vol. 186, no. 1, pp. 12-16, 1998.

[164] J. Neeleman, "Regional suicide rates in the Netherlands: does religion still play a role?" International Journal of Epidemiology, vol. 27, no. 3, pp. 466-472, 1998.

[165] J. Neeleman and G. Lewis, "Suicide, religion, and socioeconomic conditions. An ecological study in 26 countries, 1990," Journal of Epidemiology and Community Health, vol. 53, no. 4, pp. 204-210, 1999.

[166] P. A. Nisbet, P. R. Duberstein, Y. Conwell, and L. Seidlitz, "The effect of participation in religious activities on suicide versus natural death in adults 50 and older," Journal of Nervous and Mental Disease, vol. 188, no. 8, pp. 543-546, 2000.

[167] J. M. Nonnemaker, C. A. McNeely, and R. W. Blum, "Public and private domains of religiosity and adolescent health risk behaviors: evidence from the National Longitudinal Study of Adolescent Health," Social Science and Medicine, vol. 57, no. 11, pp. 2049-2054, 2003.

[168] P. S. Bearman and J. Moody, "Suicide and friendships among American adolescents," American Journal of Public Health, vol. 94, no. 1, pp. 89-95, 2004.

[169] M. P. Thompson, C. H. Ho, and J. B. Kingree, "Prospective associations between delinquency and suicidal behaviors in a nationally representative sample," Journal of Adolescent Health, vol. 40, no. 3, pp. 232-237, 2007.

[170] D. T. Rasic, S. L. Belik, B. Elias, L. Y. Katz, M. Enns, and J. Sareen, "Spirituality, religion and suicidal behavior in a nationally representative sample," Journal of Affective Disorders, vol. 114, no. 1-3, pp. 32-40, 2009.

[171] T. Sidhartha and S. Jena, "Suicidal behaviors in adolescents," Indian Journal of Pediatrics, vol. 73, no. 9, pp. 783-788, 2006.

[172] C. V. Johnson and J. A. Hayes, "Troubled spirits: prevalence of predictors of religious and spiritual concerns among university students and counseling center clients," Journal of Counseling Psychology, vol. 50, no. 4, pp. 409-419, 2003.

[173] D. R. Williams, D. B. Larson, R. E. Buckler, R. C. Heckmann, and C. M. Pyle, "Religion and psychological distress in a community sample," Social Science and Medicine, vol. 32, no. 11, pp. 1257-1262, 1991.

[174] H. G. Koenig, S. M. Fpord, L. K. George, D. G. Blazer, and K. G. Meador, "Religion and anxiety disorder: an examination and comparison of associations in young, middle-aged, and elderly adults," Journal of Anxiety Disorders, vol. 7, no. 4, pp. 321-342, 1993.

[175] M. Z. Azhar, S. L. Varma, and A. S. Dharap, "Religious psychotherapy in anxiety disorder patients," Acta Psychiatrica Scandinavica, vol. 90, no. 1, pp. 1-3, 1994.

[176] S. M. Razali, C. I. Hasanah, K. Aminah, and M. Subramaniam, "Religious-sociocultural psychotherapy in patients with anxiety and depression," Australian and New Zealand Journal of Psychiatry, vol. 32, no. 6, pp. 867-872, 1998.

[177] L. B. Cardozo, O. O. Bilukha, C. A. Gotway Crawford et al., "Mental health, social functioning, and disability in postwar Afghanistan," Journal of the American Medical Association, vol. 292, no. 5, pp. 575-584, 2004.

[178] Y. Y. Chen, "Written emotional expression and religion: effects on PTSD symptoms," International Journal of Psychiatry in Medicine, vol. 35, no. 3, pp. 273-286, 2005.

[179] D. Zehnder, A. Prchal, M. Vollrath, and M. A. Landolt, "Prospective study of the effectiveness of coping in pediatric patients," Child Psychiatry and Human Development, vol. 36, no. 3, pp. 351-368, 2006.

[180] A. B. Wachholtz and K. I. Pargament, "Migraines and meditation: does spirituality matter?" Journal of Behavioral Medicine, vol. 31, no. 4, pp. 351-366, 2008.

[181] T. D. Hill, A. M. Burdette, C. G. Ellison, and M. A. Musick, "Religious attendance and the health behaviors of Texas adults," Preventive Medicine, vol. 42, no. 4, pp. 309-312, 2006.

[182] E. Foley, A. Baillie, M. Huxter, M. Price, and E. Sinclair, "Mindfulness-based cognitive therapy for individuals whose lives have been affected by cancer: a randomized controlled trial," Journal of Consulting and Clinical Psychology, vol. 78, no. 1, pp. 72-79, 2010.

[183] M. Zeidner and A. L. Hammer, "Coping with missile attack: resources, strategies, and outcomes," Journal of Personality, vol. 60, no. 4, pp. 709-746, 1992.

[184] E. Martz, "Death anxiety as a predictor of posttraumatic stress levels among individuals with spinal cord injuries," Death Studies, vol. 28, no. 1, pp. 1-17, 2004.

[185] Z. Solomon, M. Gelkopf, and A. Bleich, "Is terror genderblind? Gender differences in reaction to terror events," Social Psychiatry and Psychiatric Epidemiology, vol. 40, no. 12, pp. 947-954, 2005.

[186] W. R. Miller, A. Forcehimes, M. J. O’Leary, and M. D. LaNoue, "Spiritual direction in addiction treatment: two clinical trials," Journal of Substance Abuse Treatment, vol. 35, no. 4, pp. 434-442, 2008.

[187] M. Hollifield, C. Hewage, C. N. Gunawardena, P. Kodituwakku, K. Bopagoda, and K. Weerarathnege, "Symptoms and coping in Sri Lanka 20-21 months after the 2004 tsunami," British Journal of Psychiatry, vol. 192, no. 1, pp. 3944, 2008.

[188] J. B. Meisenhelder and J. P. Marcum, "Terrorism, posttraumatic stress, coping strategies, and spiritual outcomes," Journal of Religion and Health, vol. 48, no. 1, pp. 46-57, 2009.

[189] M. J. Korenromp, G. C. M. L. Page-Christiaens, J. van den Bout, E. J. H. Mulder, and G. H. A. Visser, "Adjustment to 
termination of pregnancy for fetal anomaly: a longitudinal study in women at 4, 8, and 16 months," American Journal of Obstetrics and Gynecology, vol. 201, no. 2, pp. 160-e1-160-e7, 2009.

[190] W. R. Miller, A. Forcehimes, M. J. O’Leary, and M. D. LaNoue, "Spiritual direction in addiction treatment: two clinical trials," Journal of Substance Abuse Treatment, vol. 35, no. 4, pp. 434-442, 2008.

[191] A. Verghese, J. K. John, S. Rajkumar, J. Richard, B. B. Sethi, and J. K. Trivedi, "Factors associated with the course and outcome of schizophrenia in India. Results of a two-year multicentre follow-up study," British Journal of Psychiatry, vol. 154, pp. 499-503, 1989.

[192] B. B. Benda, "Factors associated with rehospitalization among veterans in a substance abuse treatment program," Psychiatric Services, vol. 53, no. 9, pp. 1176-1178, 2002.

[193] B. B. Benda, "A survival analysis of dimensions of religion among homeless substance abusers: going into the remotest regions," Marriage \& Family, vol. 5, no. 1, pp. 99-114, 2002.

[194] R. Siddle, G. Haddock, N. Tarrier, and E. B. Faragher, "Religious delusions in patients admitted to hospital with schizophrenia," Social Psychiatry and Psychiatric Epidemiology, vol. 37, no. 3, pp. 130-138, 2002.

[195] R. Lewis-Fernández, M. Horvitz-Lennon, C. Blanco, P. J. Guarnaccia, Z. Cao, and M. Alegría, "Significance of endorsement of psychotic symptoms by US latinos," Journal of Nervous and Mental Disease, vol. 197, no. 5, pp. 337-347, 2009.

[196] H. G. Koenig, "Schizophrenia and other psychotic disorders," in Religious and Spiritual Issues in Psychiatric Diagnosis: A Research Agenda For DSM-V, J. Peteet, F. G. Lu, and W. E. Narrow, Eds., chapter 2, pp. 31-52, American Psychiatric Association Press, Arlington, Va, USA, 2011.

[197] M. Cruz, H. A. Pincus, D. E. Welsh, D. Greenwald, E. Lasky, and A. M. Kilbourne, "The relationship between religious involvement and clinical status of patients with bipolar disorder," Bipolar Disorders, vol. 12, no. 1, pp. 68-76, 2010.

[198] M. Baetz, R. Bowen, G. Jones, and T. Koru-Sengul, "How spiritual values and worship attendance relate to psychiatric disorders in the Canadian population," Canadian Journal of Psychiatry, vol. 51, no. 10, pp. 654-661, 2006.

[199] G. A. Yorston, "Mania precipitated by meditation: a case report and literature review," Mental Health, Religion and Culture, vol. 4, no. 2, pp. 209-213, 2001.

[200] P. T. Costa and R. R. McCrae, "Normal personality assessment in clinical practice: the NEO personality inventory," Psychological Assessment, vol. 4, no. 1, pp. 5-13, 1992.

[201] X. H. Liu, "Eysenck personality questionnaire and Eysenck personality theory," Chinese Journal of Neurology and Psychiatry, vol. 17, no. 1, pp. 53-55, 1984.

[202] H. G. Koenig, D. E. King, and V. B. Carson, "Personality and personality disorder," in Handbook of Religion and Health, chapter 14, pp. 281-288, Oxford University Press, New York, NY, USA, 2nd edition, 2012.

[203] L. A. Jensen-Campbell, R. Adams, D. G. Perry, K. A. Workman, J. Q. Furdella, and S. K. Egan, "Agreeableness, extraversion, and peer relations in early adolescence: Winning friends and deflecting aggression," Journal of Research in Personality, vol. 36, no. 3, pp. 224-251, 2002.

[204] C. O’Cleirigh, G. Ironson, A. Weiss, and P. T. Costa, “Conscientiousness predicts disease progression (CD4 Number and Viral Load) in people living with HIV," Health Psychology, vol. 26, no. 4, pp. 473-480, 2007.
[205] R. S. Wilson, J. A. Schneider, S. E. Arnold, J. L. Bienias, and D. A. Bennett, "Conscientiousness and the incidence of Alzheimer disease and mild cognitive impairment," Archives of General Psychiatry, vol. 64, no. 10, pp. 1204-1212, 2007.

[206] I. H. Cisin and D. Cahalan, "Comparison of abstainers and heavy drinkers in a national survey.," Psychiatric Research Reports, vol. 24, pp. 10-21, 1968.

[207] A. Y. Amoateng and S. J. Bahr, "Religion, family, and adolescent drug use," Sociological Perspectives, vol. 29, no. 1, pp. 53-76, 1986.

[208] J. K. Cochran, L. Beeghley, and E. W. Bock, "Religiosity and alcohol behavior: an exploration of reference group theory," Sociological Forum, vol. 3, no. 2, pp. 256-276, 1988.

[209] E. W. Bock, J. K. Cochran, and L. Beehgley, "Moral messages: the relative influence of denomination on the religiosityalcohol relationship," Sociological Quarterly, vol. 28, no. 1, pp. 89-103, 1987.

[210] L. Beeghley, E. W. Bock, and J. K. Cochran, "Religious change and alcohol use: An application of reference group and socialization theory," Sociological Forum, vol. 5, no. 2, pp. 261-278, 1990.

[211] H. G. Koenig, L. K. George, K. G. Meador, D. G. Blazer, and S. M. Ford, "Religious practices and alcoholism in a southern adult population," Hospital and Community Psychiatry, vol. 45, no. 3, pp. 225-231, 1994.

[212] K. S. Kendler, C. O. Gardner, and C. A. Prescott, "Religion, psychopathology, and substance use and abuse: A multimeasure, genetic-epidemiologic study," American Journal of Psychiatry, vol. 154, no. 3, pp. 322-329, 1997.

[213] J. M. Wallace and T. A. Forman, "Religion's role in promoting health and reducing risk among American youth," Health Education and Behavior, vol. 25, no. 6, pp. 721-741, 1998.

[214] T. N. Brown, J. Schulenberg, J. G. Bachman, P. M. O’Malley, and L. D. Johnston, "Are risk and protective factors for substance use consistent across historical time?: national data from the high school classes of 1976 through 1997.," Prevention Science, vol. 2, no. 1, pp. 29-43, 2001.

[215] M. D. Regnerus and G. H. Elder, "Religion and vulnerability among low-risk adolescents," Social Science Research, vol. 32, no. 4, pp. 633-658, 2003.

[216] H. J. Gotham, K. J. Sher, and P. K. Wood, "Alcohol involvement and developmental task completion during young adulthood," Journal of Studies on Alcohol, vol. 64, no. 1, pp. 32-42, 2003.

[217] B. M. Booth, G. M. Curran, and X. Han, "Predictors of shortterm course of drinking in untreated rural and urban at-risk drinkers: effects of gender, illegal drug use and psychiatric comorbidity," Journal of Studies on Alcohol, vol. 65, no. 1, pp. 63-73, 2004.

[218] M. Windle, E. Y. Mun, and R. C. Windle, "Adolescentto-young adulthood heavy drinking trajectories and their prospective predictors," Journal of Studies on Alcohol, vol. 66, no. 3, pp. 313-322, 2005.

[219] W. Kliewer and L. Murrelle, "Risk and protective factors for adolescent substance use: findings from a study in selected central American countries," Journal of Adolescent Health, vol. 40, no. 5, pp. 448-455, 2007.

[220] K. M. Jackson, K. J. Sher, and J. E. Schulenberg, "Conjoint developmental trajectories of young adult substance use," Alcoholism: Clinical and Experimental Research, vol. 32, no. 5, pp. 723-737, 2008.

[221] M. E. Pagano, S. E. Zemore, C. C. Onder, and R. L. Stout, "Predictors of initial AA-related helping: findings from 
project MATCH," Journal of Studies on Alcohol and Drugs, vol. 70, no. 1, pp. 117-125, 2009.

[222] R. D. Fallot and J. P. Heckman, "Religious/spiritual coping among women trauma survivors with mental health and substance use disorders," Journal of Behavioral Health Services and Research, vol. 32, no. 2, pp. 215-226, 2005.

[223] D. Hasin, J. Endicott, and C. Lewis, "Alcohol and drug abuse in patients with affective syndromes," Comprehensive Psychiatry, vol. 26, no. 3, pp. 283-295, 1985.

[224] R. D. Hays, A. W. Stacy, D. M. R. Widaman, and R. Downey, "Multistage path models of adolescent alcohol and drug use: a reanalysis," Journal of Drug Issues, vol. 16, pp. 357-369, 1986.

[225] C. H. Amey, S. L. Albrecht, and M. K. Miller, "Racial differences in adolescent drug use: The impact of religion," Substance Use and Misuse, vol. 31, no. 10, pp. 1311-1332, 1996.

[226] R. Bell, H. Wechsler, and L. D. Johnston, "Correlates of college student marijuana use: results of a US National Survey," Addiction, vol. 92, no. 5, pp. 571-581, 1997.

[227] A. M. Trinkoff, Q. Zhou, C. L. Storr, and K. L. Soeken, "Workplace access, negative proscriptions, job strain, and substance use in registered nurses," Nursing Research, vol. 49, no. 2, pp. 83-90, 2000.

[228] L. Miller, M. Davies, and S. Greenwald, "Religiosity and substance use and abuse among adolescents in the national comorbidity survey," Journal of the American Academy of Child and Adolescent Psychiatry, vol. 39, no. 9, pp. 1190-1197, 2000.

[229] I. Sutherland and J. P. Shepherd, "Social dimensions of adolescent substance use," Addiction, vol. 96, no. 3, pp. 445458, 2001.

[230] J. Strote, J. E. Lee, and H. Wechsler, "Increasing MDMA use among college students: results of a national survey," Journal of Adolescent Health, vol. 30, no. 1, pp. 64-72, 2002.

[231] T. A. Wills, A. M. Yaeger, and J. M. Sandy, "Buffering effect of religiosity for adolescent substance use," Psychology of Addictive Behaviors, vol. 17, no. 1, pp. 24-31, 2003.

[232] J. M. Beyers, J. W. Toumbourou, R. F. Catalano, M. W. Arthur, and J. D. Hawkins, "A cross-national comparison of risk and protective factors for adolescent substance use: The United States and Australia," Journal of Adolescent Health, vol. 35, no. 1, pp. 3-16, 2004.

[233] R. K. Caputo, "Parent religiosity, family processes, and adolescent outcomes," Families in Society, vol. 85, no. 4, pp. 495-510, 2004.

[234] K. J. Steinman, "Drug selling among high school students: related risk behaviors and psychosocial characteristics," Journal of Adolescent Health, vol. 36, no. 1, pp. 71-e1, 2005.

[235] M. A. Herman-Stahl, C. P. Krebs, L. A. Kroutil, and D. C. Heller, "Risk and protective factors for nonmedical use of prescription stimulants and methamphetamine among adolescents," Journal of Adolescent Health, vol. 39, no. 3, pp. 374-380, 2006.

[236] L. Degenhardt, W. T. Chiu, N. Sampson, R. C. Kessler, and J. C. Anthony, "Epidemiological patterns of extra-medical drug use in the United States: evidence from the National Comorbidity Survey Replication, 2001-2003," Drug and Alcohol Dependence, vol. 90, no. 2-3, pp. 210-223, 2007.

[237] K. J. Steinman, A. K. Ferketich, and T. Sahr, "The doseresponse relationship of adolescent religious activity and substance use: variation across demographic groups," Health Education and Behavior, vol. 35, no. 1, pp. 22-43, 2008.
[238] Z. A. T. Harrell and C. L. Broman, "Racial/ethnic differences in correlates of prescription drug misuse among young adults," Drug and Alcohol Dependence, vol. 104, no. 3, pp. 268-271, 2009.

[239] M. A. Herman-Stahl, C. P. Krebs, L. A. Kroutil, and D. C. Heller, "Risk and protective factors for methamphetamine use and nonmedical use of prescription stimulants among young adults aged 18 to 25," Addictive Behaviors, vol. 32, no. 5, pp. 1003-1015, 2007.

[240] A. L. Rhodes and A. J. Reiss, "The, "religious factor" and delinquent behavior," Journal of Research in Crime \& Delinquency, vol. 7, pp. 83-98, 1970.

[241] R. B. Freeman, "Who escapes? The relation of churchgoing and other background factors to the socioeconomic performance of black male youths from inner-city tracts," in The Black Youth Employment Crisis, B. Richard Freeman and J. Harry Holzer, Eds., University of Chicago Press, Chicago, Ill, USA, 1986.

[242] D. M. Sloane and R. H. Potvin, "Religion and delinquency: cutting through the maze," Social Forces, vol. 65, pp. 87-105, 1986.

[243] P. L. Benson and M. J. Donahue, "Ten-year trends in at-risk behaviors: a national study of black adolescents," Journal of Adolescent Research, vol. 4, no. 4, pp. 125-139, 1989.

[244] R. Stark, "Religion as context: hellfire and delinquency one more time," Sociology of Religion, vol. 57, no. 2, pp. 163-173, 1996.

[245] B. K. Barber, "Political violence, social integration, and youth functioning: Palestinian youth from the Intifada," Journal of Community Psychology, vol. 29, no. 3, pp. 259-280, 2001.

[246] M. D. Regnerus, "Moral communities and adolescent delinquency: religious contexts and community social control," Sociological Quarterly, vol. 44, no. 4, pp. 523-554, 2003.

[247] B. B. Benda, N. J. Toombs, and M. Peacock, "Discriminators of types of recidivism among boot camp graduates in a fiveyear follow-up study," Journal of Criminal Justice, vol. 31, no. 6, pp. 539-551, 2003.

[248] L. D. Pearce and D. L. Haynie, "Intergenerational religious dynamics and adolescent delinquency," Social Forces, vol. 82, no. 4, pp. 1553-1572, 2004.

[249] B. R. Johnson, "Religious programs and recidivism among former inmates in Prison Fellowship programs: a long-term follow-up study," Justice Quarterly, vol. 21, no. 2, pp. 329354, 2004.

[250] B. Torgler, "The importance of faith: tax morale and religiosity," Journal of Economic Behavior and Organization, vol. 61, no. 1, pp. 81-109, 2006.

[251] S. Stack and A. Kposowa, "The effect of religiosity on tax fraud acceptability: a cross-national analysis," Journal for the Scientific Study of Religion, vol. 45, no. 3, pp. 325-351, 2006.

[252] J. L. Glanville, D. Sikkink, and E. I. Hernández, "Religious involvement and educational outcomes: the role of social capital and extracurricular participation," Sociological Quarterly, vol. 49, no. 1, pp. 105-137, 2008.

[253] O. Ozbay, "Does social capital deter youth from cheating, alcohol use, and violence in Turkey?: bringing torpil in," Journal of Criminal Justice, vol. 36, no. 5, pp. 403-415, 2008.

[254] H. G. Koenig, D. E. King, and V. B. Carson, "Appendix," in Handbook of Religion and Health, p. 786, Oxford University Press, New York, NY, USA, 2nd edition, 2012.

[255] W. Shrum, "Religion and marital instability: change in the 1970's?” Review of Religious Research, vol. 21, no. 2, pp. 135147, 1980. 
[256] K. R. Truett, L. J. Eaves, J. M. Meyer, A. C. Heath, and N. G. Martin, "Religion and education as mediators of attitudes: a multivariate analysis," Behavior Genetics, vol. 22, no. 1, pp. 43-62, 1992.

[257] H. Wineberg, "Marital reconciliation in the United States: which couples are successful?" Journal of Marriage and the Family, vol. 56, no. 1, pp. 80-88, 1994.

[258] J. Wilson and M. Musick, "Religion and marital dependency," Journal for the Scientific Study of Religion, vol. 35, no. 1, pp. 30-40, 1996.

[259] V. R. A. Call and T. B. Heaton, "Religious influence on marital stability," Journal For the Scientific Study of Religion, vol. 36, no. 3, pp. 382-392, 1997.

[260] W. J. Strawbridge, S. J. Shema, R. D. Cohen, and G. A. Kaplan, "Religious attendance increases survival by improving and maintaining Good health behaviors, mental health, and social relationships," Annals of Behavioral Medicine, vol. 23, no. 1, pp. 68-74, 2001.

[261] J. P. Laurenceau, S. M. Stanley, A. Olmos-Gallo, B. Baucom, and H. J. Markman, "Community-based prevention of marital dysfunction: multilevel modeling of a randomized effectiveness study," Journal of Consulting and Clinical Psychology, vol. 72, no. 6, pp. 933-943, 2004.

[262] W. B. Wilcox and N. H. Wolfinger, "Then comes marriage? Religion, race, and marriage in urban America," Social Science Research, vol. 36, no. 2, pp. 569-589, 2007.

[263] A. M. Burdette, C. G. Ellison, D. E. Sherkat, and K. A. Gore, "Are there religious variations in marital infidelity?" Journal of Family Issues, vol. 28, no. 12, pp. 1553-1581, 2007.

[264] E. Brown, T. L. Orbuch, and J. A. Bauermeister, "Religiosity and marital stability among Black American and White American couples," Family Relations, vol. 57, no. 2, pp. 186197, 2008.

[265] J. E. Uecker, "Religion, pledging, and the premarital sexual behavior of married Young adults," Journal of Marriage and Family, vol. 70, no. 3, pp. 728-744, 2008.

[266] A. Mahoney, K. I. Pargament, N. Tarakeshwar, and A. B. Swank, "Religion in the home in the 1980s and 1990s: a meta-analytic review and conceptual analysis of links between religion, marriage, and parenting," Journal of Family Psychology, vol. 15, no. 4, pp. 559-596, 2001.

[267] L. R. Hatch, "Informal support patterns of older AfricanAmerican and white women: examining effects of family, paid work, and religious participation," Research on Aging, vol. 13, no. 2, pp. 144-170, 1991.

[268] H. G. Koenig, J. C. Hays, L. K. George, D. G. Blazer, D. Larson, and L. R. Landerman, "Modeling the crosssectional relationships between religion, physical health, social support, and depressive symptoms," American Journal of Geriatric Psychiatry, vol. 5, no. 2, pp. 131-144, 1997.

[269] W. J. Strawbridge, S. J. Shema, R. D. Cohen, and G. A. Kaplan, "Religious attendance increases survival by improving and maintaining Good health behaviors, mental health, and social relationships," Annals of Behavioral Medicine, vol. 23, no. 1, pp. 68-74, 2001.

[270] M. Szaflarski, "Gender, self-reported health, and healthrelated lifestyles in Poland," Health Care for Woman International, vol. 22, no. 3, pp. 207-227, 2001.

[271] T. D. Hill, A. M. Burdette, M. Regnerus, and R. J. Angel, "Religious involvement and attitudes toward parenting among low-income Urban women," Journal of Family Issues, vol. 29, no. 7, pp. 882-900, 2008.

[272] R. J. Contrada, D. A. Boulifard, E. B. Hekler et al., "Psychosocial factors in heart surgery: presurgical vulnerability and postsurgical recovery," Health Psychology, vol. 27, no. 3, pp. 309-319, 2008.

[273] N. Krause and E. Bastida, "Core religious beliefs and providing support to others in late life," Mental Health, Religion and Culture, vol. 12, no. 1, pp. 75-96, 2009.

[274] K. M. Trevino, K. I. Pargament, S. Cotton et al., "Religious coping and physiological, psychological, social, and spiritual outcomes in patients with HIV/AIDS: cross-sectional and longitudinal findings," AIDS and Behavior, vol. 14, no. 2, pp. 379-389, 2010.

[275] S. J. Cutler, "Membership in different types of voluntary associations and psychological well being," Gerontologist, vol. 16, no. 4, pp. 335-339, 1976.

[276] H. G. Koenig, D. O. Moberg, and J. N. Kvale, "Religious activities and attitudes of older adults in a geriatric assessment clinic," Journal of the American Geriatrics Society, vol. 36, no. 4, pp. 362-374, 1988.

[277] R. Wuthnow, "Religious involvement and status-bridging social capital," Journal For the Scientific Study of Religion, vol. 41, no. 4, pp. 669-684, 2002.

[278] D. Kim and I. Kawachi, "A multilevel analysis of key forms of community- and individual-level social capital as predictors of self-rated health in the United States," Journal of Urban Health, vol. 83, no. 5, pp. 813-826, 2006.

[279] R. W. Larson, D. M. Hansen, and G. Moneta, "Differing profiles of developmental experiences across types of organized youth activities," Developmental Psychology, vol. 42, no. 5, pp. 849-863, 2006.

[280] J. L. Glanville, D. Sikkink, and E. I. Hernández, "Religious involvement and educational outcomes: the role of social capital and extracurricular participation," Sociological Quarterly, vol. 49, no. 1, pp. 105-137, 2008.

[281] The Holy Bible, New Kings James Version, Thomas Nelson Publishers, Nashville, Tenn, USA, 1982.

[282] Jewish Virtual Library, “Asceticism," 2008, http://www jewishvirtuallibrary.org/jsource/judaica/ejud_0002_0002_0_ 01417.html.

[283] L. Conrad, "Islam and the body," 2010, http://www .answers.com/topic/islam-and-the-body.

[284] Wilso, "Body, perspectives on the: an entry from macmillan reference USA's encyclopedia of Buddhism," in Macmillan Encyclopedia of Buddhism, USA, R. E. Buswell, Ed., pp. 6366, Macmillan, New York, NY, USA, 2004.

[285] H. G. Koenig, L. K. George, H. J. Cohen, J. C. Hays, D. B. Larson, and D. G. Blazer, "The relationship between religious activities and cigarette smoking in older adults," Journals of Gerontology, vol. 53, no. 6, pp. M426-M434, 1998.

[286] T. N. Brown, J. Schulenberg, J. G. Bachman, P. M. O’Malley, and L. D. Johnston, "Are risk and protective factors for substance use consistent across historical time?: national data from the high school classes of 1976 through 1997," Prevention Science, vol. 2, no. 1, pp. 29-43, 2001.

[287] M. A. Whooley, A. L. Boyd, J. M. Gardin, and D. R. Williams, "Religious involvement and cigarette smoking in young adults: the CARDIA study," Archives of Internal Medicine, vol. 162, no. 14, pp. 1604-1610, 2002.

[288] J. M. Nonnemaker, C. A. McNeely, and R. W. Blum, "Public and private domains of religiosity and adolescent health risk behaviors: evidence from the National Longitudinal Study of Adolescent Health," Social Science and Medicine, vol. 57, no. 11, pp. 2049-2054, 2003.

[289] J. M. Beyers, J. W. Toumbourou, R. F. Catalano, M. W. Arthur, and J. D. Hawkins, "A cross-national comparison of risk and protective factors for adolescent substance use: the United 
States and Australia," Journal of Adolescent Health, vol. 35, no. 1, pp. 3-16, 2004.

[290] J. Nonnemaker, C. A. McNeely, and R. W. Blum, "Public and private domains of religiosity and adolescent smoking transitions," Social Science and Medicine, vol. 62, no. 12, pp. 3084-3095, 2006.

[291] K. M. Jackson, K. J. Sher, and J. E. Schulenberg, "Conjoint developmental trajectories of young adult substance use," Alcoholism, vol. 32, no. 5, pp. 723-737, 2008.

[292] M. R. Benjamins and A. C. Buck, "Religion: a sociocultural predictor of health behaviors in Mexico," Journal of Aging and Health, vol. 20, no. 3, pp. 290-305, 2008.

[293] H. H. Yong, S. L. Hamann, R. Borland, G. T. Fong, and M. Omar, "Adult smokers' perception of the role of religion and religious leadership on smoking and association with quitting: a comparison between Thai Buddhists and Malaysian Muslims," Social Science and Medicine, vol. 69, no. 7, pp. 1025-1031, 2009.

[294] M. Feinstein, K. Liu, H. Ning, G. Fitchett, and D. M. Lloyd-Jones, "Burden of cardiovascular risk factors, subclinical atherosclerosis, and incident cardiovascular events across dimensions of religiosity: the multi-ethnic study of atherosclerosis," Circulation, vol. 121, no. 5, pp. 659-666, 2010.

[295] W. J. Strawbridge, R. D. Cohen, S. J. Shema, and G. A. Kaplan, "Frequent attendance at religious services and mortality over 28 years," American Journal of Public Health, vol. 87, no. 6, pp. 957-961, 1997.

[296] A. Kraut, S. Melamed, D. Gofer, and P. Froom, "Effect of school age sports on leisure time physical activity in adults: the CORDIS study," Medicine and Science in Sports and Exercise, vol. 35, no. 12, pp. 2038-2042, 2003.

[297] R. F. Gillum, "Frequency of attendance at religious services and leisure-time physical activity in American women and men: the Third National Health and Nutrition Examination Survey," Annals of Behavioral Medicine, vol. 31, no. 1, pp. 30 35, 2006.

[298] T. D. Hill, A. M. Burdette, C. G. Ellison, and M. A. Musick, "Religious attendance and the health behaviors of Texas adults," Preventive Medicine, vol. 42, no. 4, pp. 309-312, 2006.

[299] R. F. Gillum, D. E. King, T. O. Obisesan, and H. G. Koenig, "Frequency of attendance at religious services and mortality in a U.S. national cohort," Annals of Epidemiology, vol. 18, no. 2, pp. 124-129, 2008.

[300] M. Baetz and R. Bowen, "Chronic pain and fatigue: associations with religion and spirituality," Pain Research and Management, vol. 13, no. 5, pp. 383-388, 2008.

[301] O. Baron-Epel, A. Haviv, N. Garty, D. Tamir, and M. S. Green, "Who are the sedentary people in Israel? A public health indicator," Israel Medical Association Journal, vol. 7, no. 11, pp. 694-699, 2005.

[302] J. H. McHenry, Prayer Walk, WaterBrook Press, Colorado Springs, Colo, USA, 2001.

[303] D. R. Crawford and C. Miller, Prayer Walking, AMG Publishers, Chattanooga, Tenn, USA, 2002.

[304] T. N. Hanh and A. H. Nquyen, Walking Meditation, Sounds True, Louisville, Colo, USA, 2006.

[305] S. M. Underwood and R. L. Powell, "Religion and spirituality: influence on health/risk behavior and cancer screening behavior of African Americans.", The ABNF Journal, vol. 17, no. 1, pp. 20-31, 2006.

[306] L. A. Lytle, S. Varnell, D. M. Murray et al., "Predicting adolescents' intake of fruits and vegetables," Journal of
Nutrition Education and Behavior, vol. 35, no. 4, pp. 170-178, 2003.

[307] J. L. Locher, C. S. Ritchie, D. L. Roth, P. S. Baker, E. V. Bodner, and R. M. Allman, "Social isolation, support, and capital and nutritional risk in an older sample: Ethnic and gender differences," Social Science and Medicine, vol. 60, no. 4, pp. 747-761, 2005.

[308] C. L. Holt, D. L. Haire-Joshu, S. N. Lukwago, L. A. Lewellyn, and M. W. Kreuter, "The role of religiosity in dietary beliefs and behaviors among urban African American women.", Cancer Control, vol. 12, supplement 2, pp. 84-90, 2005.

[309] T. Obisesan, I. Livingston, H. D. Trulear, and F. Gillum, "Frequency of attendance at religious services, cardiovascular disease, metabolic risk factors and dietary intake in Americans: An age-stratified exploratory analysis," International Journal of Psychiatry in Medicine, vol. 36, no. 4, pp. 435-448, 2006.

[310] A. Hart Jr, D. J. Bowen, A. Kuniyuki, P. Hannon, and M. K. Campbell, "The relationship between the social environment within religious organizations and intake of fat versus fruits and vegetables," Health Education and Behavior, vol. 34, no. 3, pp. 503-516, 2007.

[311] Y. Friedlander, J. D. Kark, and Y. Stein, "Religious observance and plasma lipids and lipoproteins among 17-year-old Jewish residents of Jerusalem," Preventive Medicine, vol. 16, no. 1, pp. 70-79, 1987.

[312] M. S. Beeri, M. Davidson, J. M. Silverman et al., "Religious education and midlife observance are associated with dementia three decades later in Israeli men," Journal of Clinical Epidemiology, vol. 61, no. 11, pp. 1161-1168, 2008.

[313] M. Feinstein, K. Liu, H. Ning, G. Fitchett, and D. M. Lloyd-Jones, "Burden of cardiovascular risk factors, subclinical atherosclerosis, and incident cardiovascular events across dimensions of religiosity: The multi-ethnic study of atherosclerosis," Circulation, vol. 121, no. 5, pp. 659-666, 2010 .

[314] K. O. Sarri, N. E. Tzanakis, M. K. Linardakis, G. D. Mamalakis, and A. G. Kafatos, "Effects of Greek orthodox christian church fasting on serum lipids and obesity," BMC Public Health, vol. 3, pp. 1-8, 2003.

[315] R. L. Bijlani, R. P. Vempati, R. K. Yadav et al., "A brief but comprehensive lifestyle education program based on yoga reduces risk factors for cardiovascular disease and diabetes mellitus," Journal of Alternative and Complementary Medicine, vol. 11, no. 2, pp. 267-274, 2005.

[316] T. Obisesan, I. Livingston, H. D. Trulear, and F. Gillum, "Frequency of attendance at religious services, cardiovascular disease, metabolic risk factors and dietary intake in Americans: An age-stratified exploratory analysis," International Journal of Psychiatry in Medicine, vol. 36, no. 4, pp. 435-448, 2006.

[317] W. J. Strawbridge, R. D. Cohen, S. J. Shema, and G. A. Kaplan, "Frequent attendance at religious services and mortality over 28 years," American Journal of Public Health, vol. 87, no. 6, pp. 957-961, 1997.

[318] D. Oman and D. Reed, "Religion and mortality among the community-dwelling elderly," American Journal of Public Health, vol. 88, no. 10, pp. 1469-1475, 1998.

[319] K. F. Ferraro, "Firm believers? Religion, body weight, and well-being," Review of Religious Research, vol. 39, no. 3, pp. 224-244, 1998.

[320] K. H. Kim, J. Sobal, and E. Wethington, "Religion and body weight," International Journal of Obesity, vol. 27, no. 4, pp. 469-477, 2003. 
[321] M. A. Bruce, M. Sims, S. Miller, V. Elliott, and M. Ladipo, "One size fits all? Race, gender and body mass index among U.S. adults," Journal of the National Medical Association, vol. 99, no. 10, pp. 1152-1158, 2007.

[322] M. Feinstein, K. Liu, H. Ning, G. Fitchett, and D. M. Lloyd-Jones, "Burden of cardiovascular risk factors, subclinical atherosclerosis, and incident cardiovascular events across dimensions of religiosity: The multi-ethnic study of atherosclerosis," Circulation, vol. 121, no. 5, pp. 659-666, 2010.

[323] M. A. Musick, J. S. House, and D. R. Williams, "Attendance at religious services and mortality in a national sample," Journal of Health and Social Behavior, vol. 45, no. 2, pp. 198-213, 2004.

[324] K. Miller, B. Yost, S. Flaherty et al., "Health status, health conditions, and health behaviors among Amish women. Results from the Central Pennsylvania Women's Health Study (CePAWHS)," Women's Health Issues, vol. 17, no. 3, pp. 162$171,2007$.

[325] M. S. Beeri, M. Davidson, J. M. Silverman et al., "Religious education and midlife observance are associated with dementia three decades later in Israeli men," Journal of Clinical Epidemiology, vol. 61, no. 11, pp. 1161-1168, 2008.

[326] C. Arambepola, S. Allender, R. Ekanayake, and D. Fernando, "Urban living and obesity: Is it independent of its population and lifestyle characteristics?" Tropical Medicine and International Health, vol. 13, no. 4, pp. 448-457, 2008.

[327] J. Maselko, L. Kubzansky, I. Kawachi, T. Seeman, and L. Berkman, "Religious service attendance and allostatic load among high-functioning elderly," Psychosomatic Medicine, vol. 69, no. 5, pp. 464-472, 2007.

[328] S. K. Kumanyika and J. B. Charleston, "Lose weight and win: a church-based weight loss program for blood pressure control among black women," Patient Education and Counseling, vol. 19, no. 1, pp. 19-32, 1992.

[329] G. Perk, J. Ghanem, S. Aamar, D. Ben-Ishay, and M. Bursztyn, "The effect of the fast of Ramadan on ambulatory blood pressure in treated hypertensives," Journal of Human Hypertension, vol. 15, no. 10, pp. 723-725, 2001.

[330] B. M. Kennedy, S. Paeratakul, C. M. Champagne et al., "A pilot church-based weight loss program for AfricanAmerican adults using church members as health educators: A comparison of individual and group intervention," Ethnicity and Disease, vol. 15, no. 3, pp. 373-378, 2005.

[331] K. H. C. Kim, L. Linnan, M. K. Campbell, C. Brooks, H. G. Koenig, and C. Wiesen, "The WORD (wholeness, oneness, righteousness, deliverance): a Faith-based weightloss program utilizing a community-based participatory research approach," Health Education and Behavior, vol. 35, no. 5, pp. 634-650, 2008.

[332] O. Anson, A. Antonovsky, and S. Sagy, "Religiosity and well-being among retirees: a question of causality," Behavior, Health, and Aging, vol. 1, pp. 85-97, 1990.

[333] J. K. Cochran, M. B. Chamlin, L. Beeghley, and M. Fenwick, "Religion, religiosity, and nonmarital sexual conduct: an application of reference group theory," Sociological Inquiry, vol. 74, no. 1, pp. 102-158, 2004.

[334] S. N. Seidman, W. D. Mosher, and S. O. Aral, "Women with multiple sexual partners: United States, 1988," American Journal of Public Health, vol. 82, no. 10, pp. 1388-1394, 1992.

[335] C. Lammers, M. Ireland, M. Resnick, and R. Blum, "Influences on adolescents' decision to postpone onset of sexual intercourse: a survival analysis of virginity among youths aged 13 to 18 years," Journal of Adolescent Health, vol. 26, no. 1, pp. $42-48,2000$.

[336] D. C. Atkins, D. H. Baucom, and N. S. Jacobson, "Understanding infidelity: correlates in a national random sample," Journal of Family Psychology, vol. 15, no. 4, pp. 735-749, 2001.

[337] J. M. Nonnemaker, C. A. McNeely, and R. W. Blum, "Public and private domains of religiosity and adolescent health risk behaviors: evidence from the National Longitudinal Study of Adolescent Health," Social Science and Medicine, vol. 57, no. 11, pp. 2049-2054, 2003.

[338] S. S. Rostosky, M. D. Regnerus, and M. L. C. Wright, "Coital debut: the role of religiosity and sex attitudes in the add health survey," Journal of Sex Research, vol. 40, no. 4, pp. 358$367,2003$.

[339] C. T. Halpern, M. L. Young, M. W. Waller, S. L. Martin, and L. L. Kupper, "Prevalence of partner violence in same-sex romantic and sexual relationships in a national sample of adolescents," Journal of Adolescent Health, vol. 35, no. 2, pp. 124-131, 2004.

[340] R. O. D. Visser, A. M. A. Smith, J. Richters, and C. E. Rissel, "Associations between religiosity and sexuality in a representative sample of Australian adults," Archives of Sexual Behavior, vol. 36, no. 1, pp. 33-46, 2007.

[341] M. A. Whisman, K. C. Gordon, and Y. Chatav, "Predicting sexual infidelity in a population-based sample of married individuals," Journal of Family Psychology, vol. 21, no. 2, pp. 320-324, 2007.

[342] J. E. Uecker, "Religion, pledging, and the premarital sexual behavior of married Young adults," Journal of Marriage and Family, vol. 70, no. 3, pp. 728-744, 2008.

[343] A. M. Burdette, C. G. Ellison, T. D. Hill, and N. D. Glenn, "'Hooking up' at college: does religion make a difference?" Journal for the Scientific Study of Religion, vol. 48, no. 3, pp. 535-551, 2009.

[344] B. S. McEwen, "Seminars in medicine of the Beth Israel Deaconess Medical Center: protective and damaging effects of stress mediators," New England Journal of Medicine, vol. 338, no. 3, pp. 171-179, 1998.

[345] J. K. Kiecolt-Glaser, K. J. Preacher, R. C. MacCallum, C. Atkinson, W. B. Malarkey, and R. Glaser, "Chronic stress and age-related increases in the proinflammatory cytokine IL-6," Proceedings of the National Academy of Sciences of the United States of America, vol. 100, no. 15, pp. 9090-9095, 2003.

[346] S. C. Segerstrom and G. E. Miller, "Psychological stress and the human immune system: a meta-analytic study of 30 years of inquiry," Psychological Bulletin, vol. 130, no. 4, pp. 601630, 2004.

[347] S. Cohen, D. A. J. Tyrrell, and A. P. Smith, "Psychological stress and susceptibility to the common cold," New England Journal of Medicine, vol. 325, no. 9, pp. 606-612, 1991.

[348] J. A. Blumenthal, H. S. Lett, M. A. Babyak et al., "Depression as a risk factor for mortality after coronary artery bypass surgery," The Lancet, vol. 362, no. 9384, pp. 604-609, 2003.

[349] K. W. Brown, A. R. Levy, Z. Rosberger, and L. Edgar, "Psychological distress and cancer survival: a follow-up 10 years after diagnosis," Psychosomatic Medicine, vol. 65, no. 4, pp. 636-643, 2003.

[350] L. D. Kubzansky and R. C. Thurston, "Emotional vitality and incident coronary heart disease: benefits of healthy psychological functioning," Archives of General Psychiatry, vol. 64, no. 12, pp. 1393-1401, 2007.

[351] K. A. Matthews, B. B. Gump, K. F. Harris, T. L. Haney, and J. C. Barefoot, "Hostile behaviors predict cardiovascular mortality among men enrolled in the multiple risk factor 
intervention trial," Circulation, vol. 109, no. 1, pp. 66-70, 2004.

[352] E. S. Epel, E. H. Blackburn, J. Lin et al., "Accelerated telomere shortening in response to life stress," Proceedings of the National Academy of Sciences of the United States of America, vol. 101, no. 49, pp. 17312-17315, 2004.

[353] T. C. Russ, E. Stamatakis, M. Hamer, J. M. Starr, M. Kivimäki, and G. D. Batty, "Association between psychological distress and mortality: individual participant pooled analysis of 10 prospective cohort studies," British Medical Journal, vol. 345, Article ID e4933, 2012.

[354] J. S. House, K. R. Landis, and D. Umberson, "Social relationships and health," Science, vol. 241, no. 4865, pp. 540545, 1988.

[355] S. Galea, M. Tracy, K. J. Hoggatt, C. DiMaggio, and A. Karpati, "Estimated deaths attributable to social factors in the united states," American Journal of Public Health, vol. 101, no. 8, pp. 1456-1465, 2011.

[356] J. Holt-Lunstad and T. B. Smith, "Social relationships and mortality," Social and Personality Psychology Compass, vol. 6, no. 1, pp. 41-53, 2012.

[357] G. W. Comstock, "Fatal arteriosclerotic heart disease, water hardness at home, and socioeconomic characteristics," American Journal of Epidemiology, vol. 94, no. 1, pp. 1-10, 1971.

[358] Y. Friedlander, J. D. Kark, and Y. Stein, "Religious orthodoxy and myocardial infarction in Jerusalem. A case control study," International Journal of Cardiology, vol. 10, no. 1, pp. 33-41, 1986.

[359] U. Goldbourt, S. Yaari, and J. H. Medalie, "Factors predictive of long-term coronary heart disease mortality among 10,059 male Israeli civil servants and municipal employees: A 23year mortality follow-up in the Israeli ischemic heart disease study," Cardiology, vol. 82, no. 2-3, pp. 100-121, 1993.

[360] J. W. Zamarra, R. H. Schneider, I. Besseghini, D. K. Robinson, and J. W. Salerno, "Usefulness of the transcendental meditation program in the treatment of patients with coronary artery disease," American Journal of Cardiology, vol. 77, no. 10, pp. 867-870, 1996.

[361] R. Gupta, H. Prakash, V. P. Gupta, and K. D. Gupta, "Prevalence and determinants of coronary heart disease in a rural population of India," Journal of Clinical Epidemiology, vol. 50, no. 2, pp. 203-209, 1997.

[362] T. Obisesan, I. Livingston, H. D. Trulear, and F. Gillum, "Frequency of attendance at religious services, cardiovascular disease, metabolic risk factors and dietary intake in Americans: an age-stratified exploratory analysis," International Journal of Psychiatry in Medicine, vol. 36, no. 4, pp. 435-448, 2006.

[363] G. G. Berntson, G. J. Norman, L. C. Hawkley, and J. T. Cacioppo, "Spirituality and autonomic cardiac control," Annals of Behavioral Medicine, vol. 35, no. 2, pp. 198-208, 2008.

[364] G. Burazeri, A. Goda, and J. D. Kark, "Religious observance and acute coronary syndrome in predominantly Muslim Albania: a population-based case-control study in Tirana," Annals of Epidemiology, vol. 18, no. 12, pp. 937-945, 2008.

[365] B. D. Horne, H. T. May, J. L. Anderson et al., "Usefulness of routine periodic fasting to lower risk of coronary artery disease in patients undergoing coronary angiography," American Journal of Cardiology, vol. 102, no. 7, pp. 814-e1, 2008.

[366] E. Schnall, S. Wassertheil-Smoller, C. Swencionis et al., "The relationship between religion and cardiovascular outcomes and all-cause mortality in the women's health initiative observational study," Psychology and Health, vol. 25, no. 2, pp. 249-263, 2010.

[367] T. E. Oxman, D. H. Freeman, and E. D. Manheimer, "Lack of social participation or religious strength and comfort as risk factors for death after cardiac surgery in the elderly," Psychosomatic Medicine, vol. 57, no. 1, pp. 5-15, 1995.

[368] R. J. Contrada, T. M. Goyal, C. Cather, L. Rafalson, E. L. Idler, and T. J. Krause, "Psychosocial factors in outcomes of heart surgery: the impact of religious involvement and depressive symptoms," Health Psychology, vol. 23, no. 3, pp. 227-238, 2004.

[369] A. L. Ai, P. Wink, T. N. Tice, S. F. Bolling, and M. Shearer, "Prayer and reverence in naturalistic, aesthetic, and sociomoral contexts predicted fewer complications following coronary artery bypass," Journal of Behavioral Medicine, vol. 32, no. 6, pp. 570-581, 2009.

[370] K. A. Edmondson, K. A. Lawler, R. L. Jobe, J. W. Younger, R. L. Piferi, and W. H. Jones, "Spirituality predicts health and cardiovascular responses to stress in young adult women," Journal of Religion and Health, vol. 44, no. 2, pp. 161-171, 2005.

[371] Y. Y. Chen and R. J. Contrada, "Religious involvement and perceived social support: interactive effects on cardiovascular reactivity to laboratory stressors," Journal of Applied Biobehavioral Research, vol. 12, no. 1, pp. 1-12, 2007.

[372] R. Hefti, "Religion as a moderator of cardiovascular reactivity in patients with mild to severe depression," in Proceedings of the 2009 Congress of the International Association for the Psychology of Religion, Vienna, Austria, August 2009.

[373] G. G. Berntson, G. J. Norman, L. C. Hawkley, and J. T. Cacioppo, "Spirituality and autonomic cardiac control," Annals of Behavioral Medicine, vol. 35, no. 2, pp. 198-208, 2008.

[374] L. Bernardi, P. Sleight, G. Bandinelli et al., "Effect of rosary prayer and yoga mantras on autonomic cardiovascular rhythms: Comparative study," British Medical Journal, vol. 323, no. 7327, pp. 1446-1449, 2001.

[375] D. E. King, A. G. Mainous, T. E. Steyer, and W. Pearson, "The relationship between attendance at religious services and cardiovascular inflammatory markers," International Journal of Psychiatry in Medicine, vol. 31, no. 4, pp. 415-425, 2001.

[376] D. E. King, A. G. Mainous, and W. S. Pearson, "C-reactive protein, diabetes, and attendance at religious services," Diabetes Care, vol. 25, no. 7, pp. 1172-1176, 2002.

[377] E. S. Ford, E. B. Loucks, and L. F. Berkman, "Social integration and concentrations of C-reactive protein among US adults," Annals of Epidemiology, vol. 16, no. 2, pp. 78-84, 2006.

[378] E. B. Loucks, L. F. Berkman, T. L. Gruenewald, and T. E. Seeman, "Social integration is associated with fibrinogen concentration in elderly men," Psychosomatic Medicine, vol. 67, no. 3, pp. 353-358, 2005.

[379] P. A. Obrist, Cardiovascular Psychophysiology, Plenum Press, New York, NY, USA, 1981.

[380] J. H. Markovitz, B. S. Jonas, and K. Davidson, "Psychologic factors as precursors to hypertension," Current hypertension reports, vol. 3, no. 1, pp. 25-32, 2001.

[381] F. Sparrenberger, F. T. Cichelero, A. M. Ascoli et al., "Does psychosocial stress cause hypertension? A systematic review of observational studies," Journal of Human Hypertension, vol. 23, no. 1, pp. 12-19, 2009.

[382] N. A. Scotch, "Sociocultural factors in the epidemiology of Zulu hypertension," American Journal of Public Health and the Nation's Health, vol. 53, pp. 1205-1213, 1963. 
[383] T. W. Graham, B. H. Kaplan, and J. C. Cornoni-Huntley, "Frequency of church attendance and blood pressure elevation," Journal of Behavioral Medicine, vol. 1, no. 1, pp. 37-43, 1978.

[384] G. R. Stavig, A. Igra, and A. R. Leonard, "Hypertension among Asians and Pacific islanders in California," American Journal of Epidemiology, vol. 119, no. 5, pp. 677-691, 1984.

[385] M. Timio, P. Verdecchia, S. Venanzi et al., "Age and blood pressure changes. A 20-year follow-up study in nuns in a secluded order," Hypertension, vol. 12, no. 4, pp. 457-461, 1988.

[386] D. B. Larson, H. G. Koenig, B. H. Kaplan, R. S. Greenberg, E. Logue, and H. A. Tyroler, "The impact of religion on men's blood pressure," Journal of Religion \& Health, vol. 28, no. 4, pp. 265-278, 1989.

[387] I. L. Livingston, D. M. Levine, and R. D. Moore, "Social integration and black intraracial variation in blood pressure.", Ethnicity \& Disease, vol. 1, no. 2, pp. 135-149, 1991.

[388] K. L. Lapane, T. M. Lasater, C. Allan, and R. A. Carleton, "Religion and cardiovascular disease risk," Journal of Religion and Health, vol. 36, no. 2, pp. 155-163, 1997.

[389] A. Walsh, "Religion and hypertension: testing alternative explanations among immigrants," Behavioral Medicine, vol. 24, no. 3, pp. 122-130, 1998.

[390] P. R. Steffen, A. L. Hinderliter, J. A. Blumenthal, and A. Sherwood, "Religious coping, ethnicity, and ambulatory blood pressure," Psychosomatic Medicine, vol. 63, no. 4, pp. 523-530, 2001.

[391] M. Imio, P. Saronio, C. Verdura, M. Schiaroli, F. Timio, and C. Monarca, "A link between psychosocial factors and blood pressure trend in women," Physiology and Behavior, vol. 73, no. 3, pp. 359-363, 2001.

[392] Y. Y. Al-Kandari, "Religiosity and its relation to blood pressure among selected Kuwaitis," Journal of Biosocial Science, vol. 35, no. 3, pp. 463-472, 2003.

[393] R. F. Gillum and D. D. Ingram, "Frequency of attendance at religious services, hypertension, and blood pressure: the third national health and nutrition examination survey," Psychosomatic Medicine, vol. 68, no. 3, pp. 382-385, 2006.

[394] D. M. Yeager, D. A. Glei, M. Au, H. S. Lin, R. P. Sloan, and M. Weinstein, "Religious involvement and health outcomes among older persons in Taiwan," Social Science and Medicine, vol. 63, no. 8, pp. 2228-2241, 2006.

[395] C. Patel and W. R. S. North, "Randomised controlled trial of yoga and bio feedback in management of hypertension," The Lancet, vol. 2, no. 7925, pp. 93-95, 1975.

[396] C. Patel and K. K. Datey, "Relaxation and biofeedback techniques in the management of hypertension," Angiology, vol. 27, no. 2, pp. 106-113, 1976.

[397] R. Sudsuang, V. Chentanez, and K. Veluvan, "Effect of Buddhist meditation on serum cortisol and total protein levels, blood pressure, pulse rate, lung volume and reaction time," Physiology and Behavior, vol. 50, no. 3, pp. 543-548, 1991.

[398] R. H. Schneider, F. Staggers, C. N. Alexander et al., "A randomized controlled trial of stress reduction for hypertension in older African Americans," Hypertension, vol. 26, no. 5, pp. 820-827, 1995.

[399] C. N. Alexander, R. H. Schneider, F. Staggers et al., "Trial of stress reduction for hypertension in older African Americans: II. Sex and risk subgroup analysis," Hypertension, vol. 28, no. 2, pp. 228-237, 1996.

[400] S. R. Wenneberg, R. H. Schneider, K. G. Walton et al., "A controlled study of the effects of the transcendental meditation $\mathbb{R}$ program on cardiovascular reactivity and ambulatory blood pressure," International Journal of Neuroscience, vol. 89, no. 1-2, pp. 15-28, 1997.

[401] V. A. Barnes, F. A. Treiber, and H. Davis, "Impact of transcendental meditation $\mathbb{R}$ on cardiovascular function at rest and during acute stress in adolescents with high normal blood pressure," Journal of Psychosomatic Research, vol. 51, no. 4, pp. 597-605, 2001.

[402] V. A. Barnes, F. A. Treiber, and M. H. Johnson, "Impact of transcendental meditation on ambulatory blood pressure in African-American adolescents," American Journal of Hypertension, vol. 17, no. 4, pp. 366-369, 2004.

[403] R. H. Schneider, C. N. Alexander, F. Staggers et al., "A randomized controlled trial of stress reduction in African Americans treated for hypertension for over one year," American Journal of Hypertension, vol. 18, no. 1, pp. 88-98, 2005.

[404] M. Paul-Labrador, D. Polk, J. H. Dwyer et al., "Effects of a randomized controlled trial of transcendental meditation on components of the metabolic syndrome in subjects with coronary heart disease," Archives of Internal Medicine, vol. 166, no. 11, pp. 1218-1224, 2006.

[405] J. S. Levin and K. S. Markides, "Religion and health in Mexican Americans," Journal of Religion \& Health, vol. 24, no. 1, pp. 60-69, 1985.

[406] H. Topacoglu, O. Karcioglu, A. Yuruktumen et al., "Impact of Ramadan on demographics and frequencies of diseaserelated visits in the emergency department," International Journal of Clinical Practice, vol. 59, no. 8, pp. 900-905, 2005.

[407] J. Van Olphen, A. Schulz, B. Israel et al., "Religious involvement, social support, and health among African-American women on the east side of Detroit," Journal of General Internal Medicine, vol. 18, no. 7, pp. 549-557, 2003.

[408] T. M. Pollard, L. E. Carlin, R. Bhopal, N. Unwin, M. White, and C. Fischbacher, "Social networks and coronary heart disease risk factors in South Asians and Europeans in the UK," Ethnicity and Health, vol. 8, no. 3, pp. 263-275, 2003.

[409] J. Maselko, L. Kubzansky, I. Kawachi, T. Seeman, and L. Berkman, "Religious service attendance and allostatic load among high-functioning elderly," Psychosomatic Medicine, vol. 69 , no. 5, pp. 464-472, 2007.

[410] A. C. Buck, D. R. Williams, M. A. Musick, and M. J. Sternthal, "An examination of the relationship between multiple dimensions of religiosity, blood pressure, and hypertension," Social Science and Medicine, vol. 68, no. 2, pp. 314-322, 2009.

[411] G. Fitchett and L. H. Powell, "Daily spiritual experiences, systolic blood pressure, and hypertension among midlife women in swan," Annals of Behavioral Medicine, vol. 37, no. 3, pp. 257-267, 2009.

[412] K. L. Ong, B. M. Y. Cheung, Y. B. Man, C. P. Lau, and K. S. L. Lam, "Prevalence, awareness, treatment, and control of hypertension among United States adults 1999-2004," Hypertension, vol. 49, no. 1, pp. 69-75, 2007.

[413] F. Newport, "Religion and party ID strongly linked among whites, not blacks," The Gallup Poll, http://www.gallup .com/poll/148361/Religion-Party-Strongly-Linked-AmongWhites-Not-Blacks.aspx, 2012.

[414] A. Colantonio, S. V. Kasl, and A. M. Ostfeld, "Depressive symptoms and other psychosocial factors as predictors of stroke in the elderly," American Journal of Epidemiology, vol. 136, no. 7, pp. 884-894, 1992.

[415] M. M. Doody, J. S. Mandel, M. S. Linet, E. Ron, J. H. Lubin, and J. D. Boice Jr, "Mortality among Catholic nuns certified 
as radiologic technologists," American Journal of Industrial Medicine, vol. 37, no. 4, pp. 339-348, 2000.

[416] A. Castillo-Richmond, R. H. Schneider, C. N. Alexander et al., "Effects of stress reduction on carotid atherosclerosis in hypertensive African Americans," Stroke, vol. 31, no. 3, pp. 568-573, 2000.

[417] T. Obisesan, I. Livingston, H. D. Trulear, and F. Gillum, "Frequency of attendance at religious services, cardiovascular disease, metabolic risk factors and dietary intake in Americans: an age-stratified exploratory analysis," International Journal of Psychiatry in Medicine, vol. 36, no. 4, pp. 435-448, 2006.

[418] M. Feinstein, K. Liu, H. Ning, G. Fitchett, and D. M. Lloyd-Jones, "Burden of cardiovascular risk factors, subclinical atherosclerosis, and incident cardiovascular events across dimensions of religiosity: the multi-ethnic study of atherosclerosis," Circulation, vol. 121, no. 5, pp. 659-666, 2010.

[419] R. M. Sapolsky, "Glucocorticoids and hippocampal atrophy in neuropsychiatric disorders," Archives of General Psychiatry, vol. 57, no. 10, pp. 925-935, 2000.

[420] C. D. Conrad, "Chronic stress-induced hippocampal vulnerability: the glucocorticoid vulnerability hypothesis," Reviews in the Neurosciences, vol. 19, no. 6, pp. 395-411, 2008.

[421] J. G. Csernansky, H. Dong, A. M. Fagan et al., "Plasma cortisol and progression of dementia in subjects with Alzheimertype dementia," American Journal of Psychiatry, vol. 163, no. 12, pp. 2164-2169, 2006.

[422] D. A. Tata and B. J. Anderson, "The effects of chronic glucocorticoid exposure on dendritic length, synapse numbers and glial volume in animal models: implications for hippocampal volume reductions in depression," Physiology and Behavior, vol. 99, no. 2, pp. 186-193, 2010.

[423] H. G. Koenig, H. J. Cohen, D. G. Blazer et al., "Religious coping and depression among elderly, hospitalized medically ill men," American Journal of Psychiatry, vol. 149, no. 12, pp. 1693-1700, 1992.

[424] P. H. Van Ness and S. V. Kasl, "Religion and cognitive dysfunction in an elderly cohort," Journals of Gerontology, vol. 58, no. 1, pp. S21-S29, 2003.

[425] K. J. Branco, "Religious activities, strength from faith, and social functioning among African American and white nursing home residents," Journal of Religion, Spirituality and Aging, vol. 19, no. 4, pp. 3-20, 2007.

[426] T. D. Hill, A. M. Burdette, J. L. Angel, and R. J. Angel, "Religious attendance and cognitive functioning among older Mexican Americans," Journals of Gerontology, vol. 61, no. 1, pp. P3-P9, 2006.

[427] Y. Kaufman, D. Anaki, M. Binns, and M. Freedman, "Cognitive decline in Alzheimer disease: impact of spirituality, religiosity, and QOL," Neurology, vol. 68, no. 18, pp. 15091514, 2007.

[428] A. Murray-Swank, R. Goldberg, F. Dickerson, D. Medoff, K. Wohlheiter, and L. Dixon, "Correlates of religious service attendance and contact with religious leaders among persons with co-occurring serious mental illness and type 2 diabetes," Journal of Nervous and Mental Disease, vol. 195, no. 5, pp. 382-388, 2007.

[429] C. A. Reyes-Ortiz, I. M. Berges, M. A. Raji, H. G. Koenig, Y. F. Kuo, and K. S. Markides, "Church attendance mediates the association between depressive symptoms and cognitive functioning among older Mexican Americans," Journals of Gerontology, vol. 63, no. 5, pp. 480-486, 2008.
[430] E. A. Corsentino, N. Collins, N. Sachs-Ericsson, and D. G. Blazer, "Religious attendance reduces cognitive decline among older women with high levels of depressive symptoms," Journals of Gerontology, vol. 64, no. 12, pp. 1283-1289, 2009.

[431] R. M. Park, P. A. Schulte, J. D. Bowman et al., "Potential occupational risks for neurodegenerative diseases," American Journal of Industrial Medicine, vol. 48, no. 1, pp. 63-77, 2005.

[432] M. R. Benjamins, "Predictors of preventive health care use among middle-aged and older adults in Mexico: the role of religion," Journal of Cross-Cultural Gerontology, vol. 22, no. 2, pp. 221-234, 2007.

[433] M. S. Beeri, M. Davidson, J. M. Silverman et al., "Religious education and midlife observance are associated with dementia three decades later in Israeli men," Journal of Clinical Epidemiology, vol. 61, no. 11, pp. 1161-1168, 2008.

[434] A. Coin, E. Perissinotto, M. Najjar et al., "Does religiosity protect against cognitive and behavioral decline in alzheimer's dementia?" Current Alzheimer Research, vol. 7, no. 5, pp. 445-452, 2010.

[435] W. Zhang, "Religious participation, gender differences, and cognitive impairment among the oldest-old in China," Journal of Aging Research, vol. 2010, Article ID 160294, 10 pages, 2010.

[436] B. M. Jones, "Changes in cytokine production in healthy subjects practicing Guolin Qigong: a pilot study," $B M C$ Complementary and Alternative Medicine, vol. 1, p. 8, 2001.

[437] H. G. Koenig, H. J. Cohen, L. K. George, J. C. Hays, D. B. Larson, and D. G. Blazer, "Attendance at religious services, interleukin-6, and other biological parameters of immune function in older adults," International Journal of Psychiatry in Medicine, vol. 27, no. 3, pp. 233-250, 1997.

[438] T. E. Woods, M. H. Antoni, G. H. Ironson, and D. W. Kling, "Religiosity is associated with affective and immune status in symptomatic HIV-infected gay men," Journal of Psychosomatic Research, vol. 46, no. 2, pp. 165-176, 1999.

[439] G. Ironson, R. Stuetzle, and M. A. Fletcher, "An increase in religiousness/spirituality occurs after HIV diagnosis and predicts slower disease progression over 4 years in people with HIV," Journal of General Internal Medicine, vol. 21, supplement 5, pp. S62-S68, 2006.

[440] G. Ironson, R. Stuezle, M. A. Fletcher, and D. Ironson, "View of God is associated with disease progression in HIV," Annals of Behavioral Medicine, supplement 31, p. S074, 2006.

[441] G. Ironson, R. Stuetzle, D. Ironson et al., "View of God as benevolent and forgiving or punishing and judgmental predicts HIV disease progression," Journal of Behavioral Medicine, vol. 34, no. 6, pp. 414-425, 2011.

[442] G. D. Safiya, M. H. Marcia, D. Colleen, and G. Laderman, "Spiritual well-being, depressive symptoms, and immune status among women living with HIV/AIDS," Women and Health, vol. 49, no. 2-3, pp. 119-143, 2009.

[443] S. K. Lutgendorf, P. Ullrich, R. Wallace, D. Russell, and T. B. Harris, "Religious participation, interleukin-6, and mortality in older adults," Health Psychology, vol. 23, no. 5, pp. 465475, 2004.

[444] D. C. McClelland, "The effect of motivational arousal through films on salivary immunoglobulin A," Psychology and Health, vol. 2, no. 1, pp. 31-52, 1988.

[445] N. L. McCain, D. P. Gray, R. K. Elswick et al., "A randomized clinical trial of alternative stress management interventions in persons with HIV infection," Journal of Consulting and Clinical Psychology, vol. 76, no. 3, pp. 431-441, 2008. 
[446] R. J. Davidson, J. Kabat-Zinn, J. Schumacher et al., "Alterations in brain and immune function produced by mindfulness meditation," Psychosomatic Medicine, vol. 65, no. 4, pp. 564-570, 2003.

[447] T. W. W. Pace, L. T. Negi, D. D. Adame et al., "Effect of compassion meditation on neuroendocrine, innate immune and behavioral responses to psychosocial stress," Psychoneuroendocrinology, vol. 34, no. 1, pp. 87-98, 2009.

[448] S. E. Sephton, C. Koopman, M. Schaal, C. Thoresen, and D. Spiegel, "Spiritual expression and immune status in women with metastatic breast cancer: An exploratory study," Breast Journal, vol. 7, no. 5, pp. 345-353, 2001.

[449] A. T. Merchant, W. Pitiphat, B. Ahmed, I. Kawachi, and K. Joshipura, "A prospective study of social support, anger expression and risk of periodontitis in men," Journal of the American Dental Association, vol. 134, no. 12, pp. 1591-1596, 2003.

[450] J. Trinitapoli and M. D. Regnerus, "Religion and HIV risk behaviors among married men: initial results from a study in rural sub-Saharan Africa," Journal for the Scientific Study of Religion, vol. 45, no. 4, pp. 505-528, 2006.

[451] J. Tully, R. M. Viner, P. G. Coen et al., "Risk and protective factors for meningococcal disease in adolescents: matched cohort study," British Medical Journal, vol. 332, no. 7539, pp. 445-448, 2006.

[452] D. B. Pereira, L. M. Christian, S. Patidar et al., "Spiritual absence and 1-year mortality after hematopoietic stem cell transplant," Biology of Blood and Marrow Transplantation, vol. 16, no. 8, pp. 1171-1179, 2010.

[453] R. F. Gillum and C. L. Holt, "Religious involvement and seroprevalence of six infectious diseases in US adults," Southern Medical Journal, vol. 103, no. 5, pp. 403-408, 2010.

[454] G. Ironson, R. Stuetzle, and M. A. Fletcher, "An increase in religiousness/spirituality occurs after HIV diagnosis and predicts slower disease progression over 4 years in people with HIV," Journal of General Internal Medicine, vol. 21, no. 5, pp. S62-S68, 2006.

[455] H. G. Koenig and H. J. Cohen, The Link Between Religion and Health: Psychoneuroimmunology and the Faith Factor, Oxford University Press, New York, NY, USA, 2002.

[456] M. R. Irwin and A. H. Miller, "Depressive disorders and immunity: 20 years of progress and discovery," Brain, Behavior, and Immunity, vol. 21, no. 4, pp. 374-383, 2007.

[457] M. D. Schaal, S. E. Sephton, C. Thoreson, C. Koopman, and D. Spiegel, "Religious expression and immune competence in women with advanced cancer," in Proceedings of the Meeting of the American Psychological Association, San Francisco, Calif, USA, August 1998.

[458] G. Ironson, G. F. Solomon, E. G. Balbin et al., "The ironsonwoods spirituality/religiousness index is associated with long survival, health behaviors, less distress, and low cortisol in people with HIV/AIDS," Annals of Behavioral Medicine, vol. 24, no. 1, pp. 34-48, 2002.

[459] J. Tartaro, L. J. Luecken, and H. E. Gunn, "Exploring heart and soul: effects of religiosity/spirituality and gender on blood pressure and cortisol stress responses," Journal of Health Psychology, vol. 10, no. 6, pp. 753-766, 2005.

[460] A. W. Carrico, G. Ironson, M. H. Antoni et al., "A path model of the effects of spirituality on depressive symptoms and 24hurinary-free cortisol in HIV-positive persons," Journal of Psychosomatic Research, vol. 61, no. 1, pp. 51-58, 2006.

[461] J. Maselko, L. Kubzansky, I. Kawachi, T. Seeman, and L. Berkman, "Religious service attendance and allostatic load among high-functioning elderly," Psychosomatic Medicine, vol. 69, no. 5, pp. 464-472, 2007.

[462] P. Jin, "Efficacy of Tai Chi, brisk walking, meditation, and reading in reducing mental and emotional stress," Journal of Psychosomatic Research, vol. 36, no. 4, pp. 361-370, 1992.

[463] R. Sudsuang, V. Chentanez, and K. Veluvan, "Effect of Buddhist meditation on serum cortisol and total protein levels, blood pressure, pulse rate, lung volume and reaction time," Physiology and Behavior, vol. 50, no. 3, pp. 543-548, 1991.

[464] J. E. Bormann, K. Aschbacher, J. L. Wetherell, S. Roesch, and L. Redwine, "Effects of faith/assurance on cortisol levels are enhanced by a spiritual mantram intervention in adults with HIV: a randomized trial," Journal of Psychosomatic Research, vol. 66, no. 2, pp. 161-171, 2009.

[465] J. Granath, S. Ingvarsson, U. von Thiele, and U. Lundberg, "Stress management: a randomized study of cognitive behavioural therapy and yoga," Cognitive Behaviour Therapy, vol. 35, no. 1, pp. 3-10, 2006.

[466] H. G. Koenig, "Religious vs. conventional psychotherapy for major depression in patients with chronic medical illness: rationale, methods, and preliminary results," Depression Research and Treatment, vol. 2012, Article ID 460419, 11 pages, 2012.

[467] M. Wrensch, T. Chew, G. Farren et al., "Risk factors for breast cancer in a population with high incidence rates.," Breast Cancer Research, vol. 5, no. 4, pp. R88-102, 2003.

[468] A. C. MacArthur, N. D. Le, Z. U. Abanto, and R. P. Gallagher, "Occupational female breast and reproductive cancer mortality in British Columbia, Canada, 1950-94," Occupational Medicine, vol. 57, no. 4, pp. 246-253, 2007.

[469] S. M. Naguib, F. E. Lundin, and H. J. Davis, "Relation of various epidemiologic factors to cervical cancer as determined by a screening program.," Obstetrics and Gynecology, vol. 28, no. 4, pp. 451-459, 1966.

[470] J. W. Gardner and J. L. Lyon, "Cancer in Utah Mormon men by lay priesthood level," American Journal of Epidemiology, vol. 116, no. 2, pp. 243-257, 1982.

[471] J. W. Gardner and J. L. Lyon, "Cancer in Utah Mormon women by Church activity level," American Journal of Epidemiology, vol. 116, no. 2, pp. 258-265, 1982.

[472] G. I. Ringdal, "Religiosity, quality of life, and survival in cancer patients," Social Indicators Research, vol. 38, no. 2, pp. 193-211, 1996.

[473] J. E. Enstrom, "Health practices and cancer mortality among active California Mormons," Journal of the National Cancer Institute, vol. 81, no. 23, pp. 1807-1814, 1989.

[474] J. W. Dwyer, L. L. Clarke, and M. K. Miller, "The effect of religious concentration and affiliation on county cancer mortality rates," Journal of Health and Social Behavior, vol. 31, no. 2, pp. 185-202, 1990.

[475] P. H. Van Ness, S. V. Kasl, and B. A. Jones, "Religion, race, and breast cancer survival," International Journal of Psychiatry in Medicine, vol. 33, no. 4, pp. 357-375, 2003.

[476] A. Y. Kinney, L. E. Bloor, W. N. Dudley et al., "Roles of religious involvement and social support in the risk of colon cancer among blacks and whites," American Journal of Epidemiology, vol. 158, no. 11, pp. 1097-1107, 2003.

[477] M. Daniels, R. M. Merrill, J. L. Lyon, J. B. Stanford, and G. L. White Jr, "Associations between breast cancer risk factors and religious practices in Utah," Preventive Medicine, vol. 38, no. 1, pp. 28-38, 2004. 
[478] Y. K. Wong, W. C. Tsai, J. C. Lin et al., "Socio-demographic factors in the prognosis of oral cancer patients," Oral Oncology, vol. 42, no. 9, pp. 893-906, 2006.

[479] C. Cucino and A. Sonnenberg, "Occupational mortality from squamous cell carcinoma of the esophagus in the United States during 1991-1996," Digestive Diseases and Sciences, vol. 47, no. 3, pp. 568-572, 2002.

[480] E. Schnall, S. Wassertheil-Smoller, C. Swencionis et al., "The relationship between religion and cardiovascular outcomes and all-cause mortality in the women's health initiative observational study," Psychology and Health, vol. 25, no. 2, pp. 249-263, 2010.

[481] S. Cohen, D. Janicki-Deverts, and G. E. Miller, "Psychological stress and disease," Journal of the American Medical Association, vol. 298, no. 14, pp. 1685-1687, 2007.

[482] Y. Chida, M. Hamer, J. Wardle, and A. Steptoe, "Do stressrelated psychosocial factors contribute to cancer incidence and survival?" Nature Clinical Practice Oncology, vol. 5, no. 8, pp. 466-475, 2008.

[483] E. L. Idler, "Religious involvement and the health of the elderly: some hypotheses and an initial test," Social Forces, vol. 66, pp. 226-238, 1987.

[484] E. L. Idler and S. V. Kasl, "Religion among disabled and nondisabled persons II: attendance at religious services as a predictor of the course of disability," Journals of Gerontology, vol. 52, no. 6, pp. S306-S316, 1997.

[485] P. Pressman, J. S. Lyons, D. B. Larson, and J. J. Strain, "Religious belief, depression, and ambulation status in elderly women with broken hips," American Journal of Psychiatry, vol. 147 , no. 6, pp. 758-760, 1990.

[486] M. R. Benjamins, M. A. Musick, D. T. Gold, and L. K. George, "Age-related declines in activity level: the relationship between chronic illness and religious activities," Journals of Gerontology, vol. 58, no. 6, pp. S377-S385, 2003.

[487] N. Morrow-Howell, J. Hinterlong, P. A. Rozario, and F. Tang, "Effects of volunteering on the well-being of older adults," Journals of Gerontology, vol. 58, no. 3, pp. S137-S145, 2003.

[488] B. Lopes Cardozo, O. O. Bilukha, C. A. Gotway Crawford et al., "Mental health, social functioning, and disability in postwar Afghanistan," Journal of the American Medical Association, vol. 292, no. 5, pp. 575-584, 2004.

[489] C. A. Reyes-Ortiz, H. Ayele, T. Mulligan, D. V. Espino, I. M. Berges, and K. S. Markides, "Higher church attendance predicts lower fear of falling in older Mexican-Americans," Aging and Mental Health, vol. 10, no. 1, pp. 13-18, 2006.

[490] A. L. Ai, C. Peterson, S. F. Bolling, and W. Rodgers, "Depression, faith-based coping, and short-term postoperative global functioning in adult and older patients undergoing cardiac surgery," Journal of Psychosomatic Research, vol. 60, no. 1, pp. 21-28, 2006.

[491] K. J. Branco, "Religious activities, strength from faith, and social functioning among African American and white nursing home residents," Journal of Religion, Spirituality and Aging, vol. 19, no. 4, pp. 3-20, 2007.

[492] T. A. Arcury, J. M. Stafford, R. A. Bell, S. L. Golden, B. M. Snively, and S. A. Quandt, "The association of health and functional status with private and public religious practice among rural, ethnically diverse, older adults with diabetes," Journal of Rural Health, vol. 23, no. 3, pp. 246-253, 2007.

[493] I. M. Berges, Y. F. Kuo, K. S. Markides, and K. Ottenbacher, "Attendance at religious services and physical functioning after stroke among older Mexican Americans," Experimental Aging Research, vol. 33, no. 1, pp. 1-11, 2007.
[494] N. S. Park, D. L. Klemmack, L. L. Roff et al., "Religiousness and longitudinal trajectories in elders' functional status," Research on Aging, vol. 30, no. 3, pp. 279-298, 2008.

[495] P. Tekur, C. Singphow, H. R. Nagendra, and N. Raghuram, "Effect of short-term intensive yoga program on pain, functional disability and spinal flexibility in chronic low back pain: a randomized control study," Journal of Alternative and Complementary Medicine, vol. 14, no. 6, pp. 637-644, 2008.

[496] E. L. Idler, "Religion, health, and nonphysical senses of self," Social Forces, vol. 74, pp. 683-704, 1995.

[497] G. E. Hendershot, "Mobility limitations and complementary and alternative medicine: are people with disabilities more likely to pray?" American Journal of Public Health, vol. 93, no. 7, pp. 1079-1080, 2003.

[498] K. I. Pargament, H. G. Koenig, N. Tarakeshwar, and J. Hahn, "Religious coping methods as predictors of psychological, physical and spiritual outcomes among medically ill elderly patients: a two-year longitudinal study," Journal of Health Psychology, vol. 9, no. 6, pp. 713-730, 2004.

[499] E. Gilgil, C. Kaçar, B. Bütün et al., "Prevalence of low back pain in a developing urban setting," Spine, vol. 30, no. 9, pp. 1093-1098, 2005.

[500] A. L. Ai, C. Peterson, S. F. Bolling, and W. Rodgers, "Depression, faith-based coping, and short-term postoperative global functioning in adult and older patients undergoing cardiac surgery," Journal of Psychosomatic Research, vol. 60, no. 1, pp. 21-28, 2006.

[501] A. Shmueli, "Health and religiosity among Israeli Jews," European Journal of Public Health, vol. 17, no. 1, pp. 104-111, 2007.

[502] M. R. Benjamins, "Religion and functional health among the elderly: is there a relationship and is it constant?" Journal of Aging and Health, vol. 16, no. 3, pp. 355-374, 2004.

[503] H. G. Koenig, L. K. George, and P. Titus, "Religion, spirituality, and health in medically Ill hospitalized older patients," Journal of the American Geriatrics Society, vol. 52, no. 4, pp. 554-562, 2004.

[504] K. R. Martin and B. R. Levy, "Opposing trends of religious attendance and religiosity in predicting elders' functional recovery after an acute myocardial infarction," Journal of Religion and Health, vol. 45, no. 3, pp. 440-451, 2006.

[505] P. A. Bath, "Self-rated health as a risk factor for prescribed drug use and future health and social service use in older people," Journals of Gerontology, vol. 54, no. 11, pp. M565M570, 1999.

[506] E. L. Idler and Y. Benyamini, "Self-rated health and mortality: a review of twenty-seven community studies," Journal of Health and Social Behavior, vol. 38, no. 1, pp. 21-37, 1997.

[507] M. Jylhä, "What is self-rated health and why does it predict mortality? Towards a unified conceptual model," Social Science and Medicine, vol. 69, no. 3, pp. 307-316, 2009.

[508] M. A. Musick, "Religion and subjective health among black and white elders," Journal of Health and Social Behavior, vol. 37, no. 3, pp. 221-237, 1996.

[509] N. Krause, "Neighborhood deterioration, religious coping, and changes in health during late life," Gerontologist, vol. 38, no. 6, pp. 653-664, 1998.

[510] J. Levin, "God, love, and health: findings from a clinical study," Review of Religious Research, vol. 42, no. 3, pp. 277293, 2001.

[511] M. T. Hyyppä and J. Mäki, "Individual-level relationships between social capital and self-rated health in a bilingual community," Preventive Medicine, vol. 32, no. 2, pp. 148-155, 2001. 
[512] N. Krause, "Church-based social support and health in old age: exploring variations by race," Journals of Gerontology, vol. 57 , no. 6 , pp. S332-S347, 2002.

[513] B. K. Finch and W. A. Vega, "Acculturation stress, social support, and self-rated health among Latinos in California.", Journal of immigrant health, vol. 5, no. 3, pp. 109-117, 2003.

[514] J. Van Olphen, A. Schulz, B. Israel et al., "Religious involvement, social support, and health among African-American women on the east side of Detroit," Journal of General Internal Medicine, vol. 18, no. 7, pp. 549-557, 2003.

[515] M. E. McCullough and J. P. Laurenceau, "Religiousness and the trajectory of self-rated health across adulthood," Personality and Social Psychology Bulletin, vol. 31, no. 4, pp. 560-573, 2005.

[516] N. Krause, "Exploring the stress-buffering effects of churchbased and secular social support on self-rated health in late life," Journals of Gerontology, vol. 61, no. 1, pp. S35-S43, 2006.

[517] N. Krause, "Gratitude toward God, stress, and health in late life," Research on Aging, vol. 28, no. 2, pp. 163-183, 2006.

[518] D. Kim and I. Kawachi, "A multilevel analysis of key forms of community- and individual-level social capital as predictors of self-rated health in the United States," Journal of Urban Health, vol. 83, no. 5, pp. 813-826, 2006.

[519] A. Sujoldžić, L. Peternel, T. Kulenović, and R. Terzić, "Social determinants of health-a comparative study of Bosnian adolescents in different cultural contexts," Collegium Antropologicum, vol. 30, no. 4, pp. 703-711, 2006.

[520] C. A. Reyes-Ortiz, M. Pelaez, H. G. Koenig, and T. Mulligan, "Religiosity and self-rated health among Latin American and Caribbean elders," International Journal of Psychiatry in Medicine, vol. 37, no. 4, pp. 425-443, 2007.

[521] R. F. Gillum, D. E. King, T. O. Obisesan, and H. G. Koenig, "Frequency of attendance at religious services and mortality in a U.S. National cohort," Annals of Epidemiology, vol. 18, no. 2, pp. 124-129, 2008.

[522] L. B. Koenig and G. E. Vaillant, "A prospective study of church attendance and health over the lifespan," Health Psychology, vol. 28, no. 1, pp. 117-124, 2009.

[523] N. Krause, "Church-based volunteering, providing informal support at church, and self-rated health in late life," Journal of Aging and Health, vol. 21, no. 1, pp. 63-84, 2009.

[524] N. Krause, "Religious involvement, humility, and self-rated health," Social Indicators Research, vol. 98, no. 1, pp. 23-39, 2010.

[525] N. Krause, "Close companions at church, health, and health care use in late life," Journal of Aging and Health, vol. 22, no. 4, pp. 434-453, 2010.

[526] N. Krause, "God-mediated control and change in self-rated health," International Journal for the Psychology of Religion, vol. 20, no. 4, pp. 267-287, 2010.

[527] R. K. Caputo, "Parent religiosity, family processes, and adolescent outcomes," Families in Society, vol. 85, no. 4, pp. 495-510, 2004.

[528] M. R. Benjamins, "Predictors of preventive health care use among middle-aged and older adults in Mexico: the role of religion," Journal of Cross-Cultural Gerontology, vol. 22, no. 2, pp. 221-234, 2007.

[529] L. E. Ross, I. J. Hall, T. L. Fairley, Y. J. Taylor, and D. L. Howard, "Prayer and self-reported health among cancer survivors in the United States, National Health Interview Survey, 2002," Journal of Alternative and Complementary Medicine, vol. 14, no. 8, pp. 931-938, 2008.

[530] T. A. Cronan, R. M. Kaplan, L. Posner, E. Blumberg, and F. Kozin, "Prevalence of the use of unconventional remedies for arthritis in a metropolitan community," Arthritis and Rheumatism, vol. 32, no. 12, pp. 1604-1607, 1989.

[531] A. B. Wachholtz and M. J. Pearce, "Does spirituality as a coping mechanism help or hinder coping with chronic pain?" Current Pain and Headache Reports, vol. 13, no. 2, pp. 127132, 2009.

[532] A. B. Wachholtz and M. J. Pearce, "Does spirituality as a coping mechanism help or hinder coping with chronic pain?" Current Pain and Headache Reports, vol. 13, no. 2, pp. 127$132,2009$.

[533] J. M. Charcot, “Lemon d'ouverture," Progrès Médical, vol. 10, p. 336, 1882.

[534] J. A. Turner and S. Clancy, "Strategies for coping with chronic low back pain: relationship to pain and disability," Pain, vol. 24, no. 3, pp. 355-364, 1986.

[535] J. Kabat-Zinn, L. Lipworth, and R. Burney, "The clinical use of mindfulness meditation for the self-regulation of chronic pain," Journal of Behavioral Medicine, vol. 8, no. 2, pp. 163190, 1985.

[536] A. B. Wachholtz and K. I. Pargament, "Is spirituality a critical ingredient of meditation? Comparing the effects of spiritual meditation, secular meditation, and relaxation on spiritual, psychological, cardiac, and pain outcomes," Journal of Behavioral Medicine, vol. 28, no. 4, pp. 369-384, 2005.

[537] P. J. John, N. Sharma, C. M. Sharma, and A. Kankane, "Effectiveness of yoga therapy in the treatment of migraine without aura: a randomized controlled trial," Headache, vol. 47, no. 5, pp. 654-661, 2007.

[538] K. Wiech, R. Kalisch, N. Weiskopf, B. Pleger, K. E. Stephan, and R. J. Dolan, "Anterolateral prefrontal cortex mediates the analgesic effect of expected and perceived control over pain," Journal of Neuroscience, vol. 26, no. 44, pp. 11501-11509, 2006.

[539] P. Tekur, C. Singphow, H. R. Nagendra, and N. Raghuram, "Effect of short-term intensive yoga program on pain, functional disability and spinal flexibility in chronic low back pain: a randomized control study," Journal of Alternative and Complementary Medicine, vol. 14, no. 6, pp. 637-644, 2008.

[540] A. B. Wachholtz and K. I. Pargament, "Migraines and meditation: does spirituality matter?" Journal of Behavioral Medicine, vol. 31, no. 4, pp. 351-366, 2008.

[541] J. A. Grant and P. Rainville, "Pain sensitivity and analgesic effects of mindful states in zen meditators: a cross-sectional study," Psychosomatic Medicine, vol. 71, no. 1, pp. 106-114, 2009.

[542] J. A. Grant, J. Courtemanche, E. G. Duerden, G. H. Duncan, and P. Rainville, "Cortical thickness and pain sensitivity in Zen meditators," Emotion, vol. 10, no. 1, pp. 43-53, 2010.

[543] K. J. Branco, "Religiosity and depression among nursing home residents: results of a survey of ten states," Journal of Religious Gerontology, vol. 12, no. 1, pp. 43-61, 2000.

[544] L. Cohen, R. T. Fouladi, and J. Katz, "Preoperative coping strategies and distress predict postoperative pain and morphine consumption in women undergoing abdominal gynecologic surgery," Journal of Psychosomatic Research, vol. 58, no. 2, pp. 201-209, 2005.

[545] G. Andersson, "Chronic pain and praying to a higher power: useful or useless?" Journal of Religion and Health, vol. 47, no. 2, pp. 176-187, 2008.

[546] A. B. Wachholtz and K. I. Pargament, "Is spirituality a critical ingredient of meditation? Comparing the effects of spiritual meditation, secular meditation, and relaxation on spiritual, psychological, cardiac, and pain outcomes," Journal of Behavioral Medicine, vol. 28, no. 4, pp. 369-384, 2005. 
[547] A. B. Wachholtz and K. I. Pargament, "Migraines and meditation: does spirituality matter?" Journal of Behavioral Medicine, vol. 31, no. 4, pp. 351-366, 2008.

[548] V. J. Schoenbach, B. H. Kaplan, L. Fredman, and D. G. Kleinbaum, "Social ties and mortality in Evans county, Georgia," American Journal of Epidemiology, vol. 123, no. 4, pp. 577-591, 1986.

[549] S. Bryant and W. Rakowski, "Predictors of mortality among elderly African-Americans," Research on Aging, vol. 14, no. 1, pp. 50-67, 1992.

[550] J. D. Kark, G. Shemi, Y. Friedlander, O. Martin, O. Manor, and S. H. Blondheim, "Does religious observance promote health? Mortality in secular vs religious Kibbutzim in Israel," American Journal of Public Health, vol. 86, no. 3, pp. 341-346, 1996.

[551] W. J. Strawbridge, R. D. Cohen, S. J. Shema, and G. A. Kaplan, "Frequent attendance at religious services and mortality over 28 years," American Journal of Public Health, vol. 87, no. 6, pp. 957-961, 1997.

[552] H. G. Koenig, "Does religious attendance prolong survival? a six-year follow-up study of 3,968 older adults," Journals of Gerontology, vol. 54, no. 7, pp. M370-M376, 1999.

[553] R. A. Hummer, R. G. Rogers, C. B. Nam, and C. G. Ellison, "Religious involvement and U.S. adult mortality," Demography, vol. 36, no. 2, pp. 273-285, 1999.

[554] H. M. Helm, J. C. Hays, E. P. Flint, H. G. Koenig, and D. G. Blazer, "Does private religious activity prolong survival? A six-year follow-up study of 3,851 older adults," Journals of Gerontology, vol. 55, no. 7, pp. M400-M405, 2000.

[555] C. G. Ellison, R. A. Hummer, S. Cormier, and R. G. Rogers, "Religious involvement and mortality risk among African American adults," Research on Aging, vol. 22, no. 6, pp. 630667, 2000.

[556] P. M. Eng, E. B. Rimm, G. Fitzmaurice, and I. Kawachi, "Social ties and change in social ties in relation to subsequent total and cause-specific mortality and coronary heart disease incidence in men," American Journal of Epidemiology, vol. 155 , no. 8, pp. 700-709, 2002.

[557] S. K. Lutgendorf, P. Ullrich, R. Wallace, D. Russell, and T. B. Harris, "Religious participation, interleukin-6, and mortality in older adults," Health Psychology, vol. 23, no. 5, pp. 465475, 2004.

[558] A. H. S. Harris and C. E. Thoresen, "Volunteering is associated with delayed mortality in older people: analysis of the longitudinal study of aging," Journal of Health Psychology, vol. 10, no. 6, pp. 739-752, 2005.

[559] T. D. Hill, J. L. Angel, C. G. Ellison, and R. J. Angel, "Religious attendance and mortality: an 8-year follow-up of older Mexican Americans.," The Journals of Gerontology, vol. 60, no. 2, pp. S102-109, 2005.

[560] M. E. Dupre, A. T. Franzese, and E. A. Parrado, "Religious attendance and mortality: implications for the black-white mortality crossover," Demography, vol. 43, no. 1, pp. 141-164, 2006.

[561] W. Zhang, "Religious participation and mortality risk among the oldest old in China," Journals of Gerontology, vol. 63, no. 5, pp. S293-S297, 2008.

[562] J. E. Enstrom and L. Breslow, "Lifestyle and reduced mortality among active California Mormons, 1980-2004," Preventive Medicine, vol. 46, no. 2, pp. 133-136, 2008.

[563] G. Ironson and H. Kremer, "Spiritual transformation, psychological well-being, health, and survival in people with HIV," International Journal of Psychiatry in Medicine, vol. 39, no. 3, pp. 263-281, 2009.
[564] M. E. McCullough, H. S. Friedman, C. K. Enders, and L. R. Martin, "Does devoutness delay death? Psychological investment in religion and its association with longevity in the terman sample," Journal of Personality and Social Psychology, vol. 97, no. 5, pp. 866-882, 2009.

[565] E. Schnall, S. Wassertheil-Smoller, C. Swencionis et al., "The relationship between religion and cardiovascular outcomes and all-cause mortality in the women's health initiative observational study," Psychology and Health, vol. 25, no. 2, pp. 249-263, 2010.

[566] R. A. Hummer, M. R. Benjamins, C. G. Ellison, and R. G. Rogers, "Religious involvement and mortality risk among pre-retirement aged U.S. adults," in Religion, Families, and Health: Population-Based Research in the United States, C. G. Ellison and R. A. Hummer, Eds., pp. 273-291, Rutgers Press, Piscataway, NJ, USA, 2010.

[567] G. R. Parkerson Jr and R. A. Gutman, "Health-related quality of life predictors of survival and hospital utilization," Health Care Financing Review, vol. 21, no. 3, pp. 171-184, 2000.

[568] R. M. Park, P. A. Schulte, J. D. Bowman et al., "Potential occupational risks for neurodegenerative diseases," American Journal of Industrial Medicine, vol. 48, no. 1, pp. 63-77, 2005.

[569] E. Schnall, S. Wassertheil-Smoller, C. Swencionis et al., "The relationship between religion and cardiovascular outcomes and all-cause mortality in the women's health initiative observational study," Psychology and Health, vol. 25, no. 2, pp. 249-263, 2010.

[570] L. H. Powell, L. Shahabi, and C. E. Thoresen, "Religion and spirituality: linkages to physical health," American Psychologist, vol. 58, no. 1, pp. 36-52, 2003.

[571] M. E. McCullough, W. T. Hoyt, D. B. Larson, H. G. Koenig, and C. Thoresen, "Religious involvement and mortality: a meta-analytic review," Health Psychology, vol. 19, no. 3, pp. 211-222, 2000.

[572] Y. Chida, A. Steptoe, and L. H. Powell, "Religiosity/spirituality and mortality: a systematic quantitative review," Psychotherapy and Psychosomatics, vol. 78, no. 2, pp. 81-90, 2009.

[573] M. McCullough, "Religious involvement and mortality," in Faith and Health: Psychological Perspectives, T. G. Plane and A. C. Sherman, Eds., pp. 53-74, Guilford Press, New York, NY, USA, 2001.

[574] J. S. House, K. R. Landis, and D. Umberson, "Social relationships and health," Science, vol. 241, no. 4865, pp. 540545, 1988.

[575] S. Cohen, L. G. Underwood, and B. H. Gottlieb, Social Support, Measurement, and Intervention: A Guide For Health and Social Scientists, Oxford University Press, New York, NY, USA, 2000.

[576] B. N. Uchino, "Understanding the links between social support and physical health," Perspectives on Psychological Science, vol. 4, no. 3, pp. 236-255, 2009.

[577] H. G. Koenig, D. E. King, and V. B. Carson, Handbook of Religion and Health, Oxford University Press, New York, NY, USA, 2nd edition, 2012.

[578] H. G. Koenig, Spirituality in Patient Care, Templeton Press, Conshohocken, Pa, USA, 3rd edition, 2013.

[579] G. Fitchett, L. A. Burton, and A. B. Sivan, "The religious needs and resources of psychiatric inpatients," Journal of Nervous and Mental Disease, vol. 185, no. 5, pp. 320-326, 1997.

[580] T. A. Balboni, L. C. Vanderwerker, S. D. Block et al., "Religiousness and spiritual support among advanced cancer 
patients and associations with end-of-life treatment preferences and quality of life," Journal of Clinical Oncology, vol. 25, no. 5, pp. 555-560, 2007.

[581] K. I. Pargament, H. G. Koenig, N. Tarakeshwar, and J. Hahn, "Religious struggle as a predictor of mortality among medically ill elderly patients: a 2-Year longitudinal study," Archives of Internal Medicine, vol. 161, no. 15, pp. 1881-1885, 2001.

[582] H. G. Koenig, "Religious beliefs and practices of hospitalized medically Ill older adults," International Journal of Geriatric Psychiatry, vol. 13, pp. 213-224, 1998.

[583] H. G. Koenig, F. Shelp, V. Goli, H. J. Cohen, and D. G. Blazer, "Survival and health care utilization in elderly medical inpatients with major depression," Journal of the American Geriatrics Society, vol. 37, no. 7, pp. 599-606, 1989.

[584] J. W. Ehman, B. B. Ott, T. H. Short, R. C. Ciampa, and J. Hansen-Flaschen, "Do patients want physicians to inquire about their spiritual or religious beliefs if they become gravely ill?" Archives of Internal Medicine, vol. 159, no. 15, pp. 1803-1806, 1999.

[585] G. McCord, V. J. Gilchrist, S. D. Grossman et al., "Discussing spirituality with patients: a rational and ethical approach," Annals of Family Medicine, vol. 2, no. 4, pp. 356-361, 2004.

[586] G. A. Silvestri, S. Knittig, J. S. Zoller, and P. J. Nietert, "Importance of faith on medical decisions regarding cancer care," Journal of Clinical Oncology, vol. 21, no. 7, pp. 13791382, 2003.

[587] L. C. Kaldjian, J. F. Jekel, and G. Friedland, "End-of-life decisions in HIV-positive patientsthe role of spiritual beliefs," AIDS, vol. 12, no. 1, pp. 103-107, 1998.

[588] F. A. Curlin, R. E. Lawrence, M. H. Chin, and J. D. Lantos, "Religion, conscience, and controversial clinical practices," New England Journal of Medicine, vol. 356, no. 6, pp. 593 600, 2007.

[589] D. B. Stulberg, A. M. Dude, and I. Dahlquist, "Abortion provision among practicing obstetrician-gynecologists," Curlin FAObstetrics \& Gynecology, vol. 118, no. 3, pp. 609-614, 2011.

[590] K. L. Ishibashi, J. Koopmans, F. A. Curlin, K. A. Alexander, and L. F. Ross, "Paediatricians' attitudes and practices towards HPV vaccination," Acta Paediatrica, International Journal of Paediatrics, vol. 97, no. 11, pp. 1550-1556, 2008.

[591] R. E. Lawrence, K. A. Rasinski, J. D. Yoon, and F. A. Curlin, "Obstetrician-gynecologist physicians' beliefs about emergency contraception: a national survey," Contraception, vol. 82, no. 4, pp. 324-330, 2010.

[592] T. Balboni, M. Balboni, M. E. Paulk et al., "Support of cancer patients' spiritual needs and associations with medical care costs at the end of life," Cancer, 2011.

[593] Centers for Medicare and Medicaid Services (CMS), State Operations Manual, Appendix M-Guidance to Surveyors: Hospice, https://www.cms.gov/manuals/downloads/som107ap_m_hospice.pdf.

[594] H. G. Koenig, "An 83-year-old woman with chronic illness and strong religious beliefs," Journal of the American Medical Association, vol. 288, no. 4, pp. 487-493, 2002.

[595] F. A. Curlin, M. H. Chin, S. A. Sellergren, C. J. Roach, and J. D. Lantos, "The association of physicians' religious characteristics with their attitudes and self-reported behaviors regarding religion and spirituality in the clinical encounter," Medical Care, vol. 44, no. 5, pp. 446-453, 2006.

[596] H. G. Koenig, E. G. Hooten, E. Lindsay-Calkins, and K. G. Meador, "Spirituality in medical school curricula: findings from a national survey." International Journal of Psychiatry in Medicine, vol. 40, no. 4, pp. 391-398, 2010.
[597] D. Neely and E. J. Minford, "Current status of teaching on spirituality in UK medical schools," Medical Education, vol. 42, no. 2, pp. 176-182, 2008.

[598] G. Lucchetti, D. C. M. Espinha, L. R. de Oliveira, J. R. Leite, A. L. G. Lucchetti, and H. G. Koenig, "Spirituality and health in the curricula of medical schools in Brazil," BMC Medical Education, vol. 12, p. 78, 2012.

[599] H. G. Koenig, "Information on specific religions," in Spirituality in Patient Care, ch 13, pp. 188-227, Templeton Press, Conshohocken, PA, 2nd edition, 2007.

[600] H. G. Koenig, D. E. King, and V. B. Carson, Handbook of Religion and Health, Oxford University Press, New York, NY, USA, 2nd edition, 2012.

[601] H. G. Koenig, Spirituality in Patient Care, Templeton Press, Conshohocken, Pa, USA, 3rd edition, 2013. 


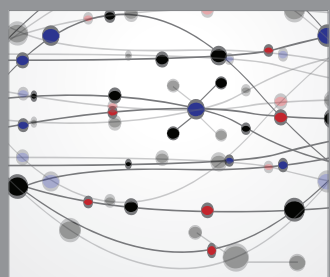

The Scientific World Journal
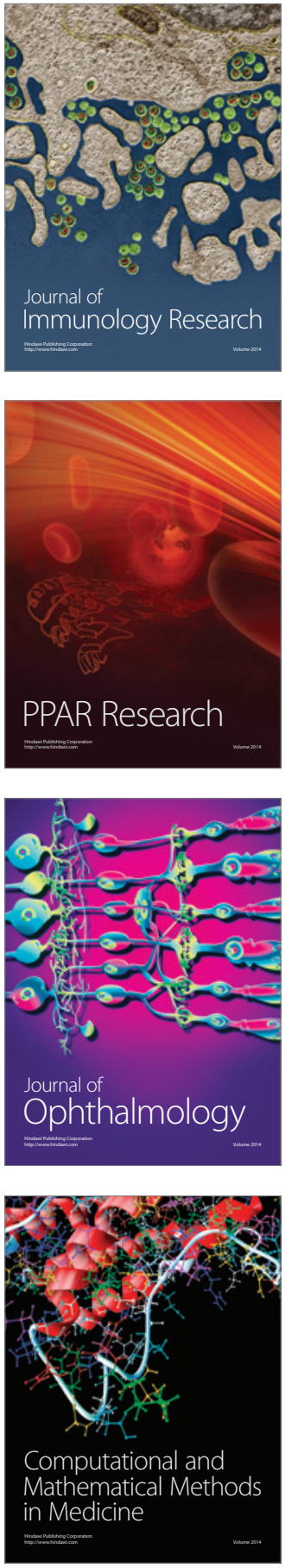

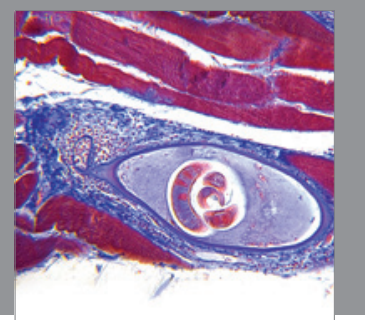

Gastroenterology

Research and Practice
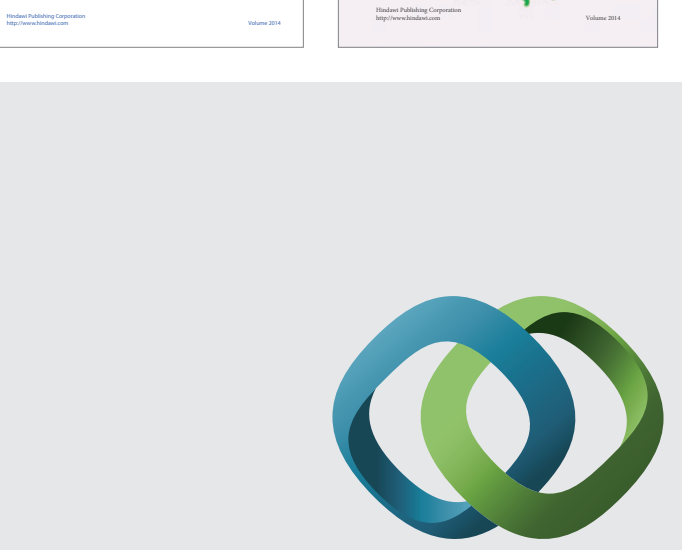

\section{Hindawi}

Submit your manuscripts at

http://www.hindawi.com
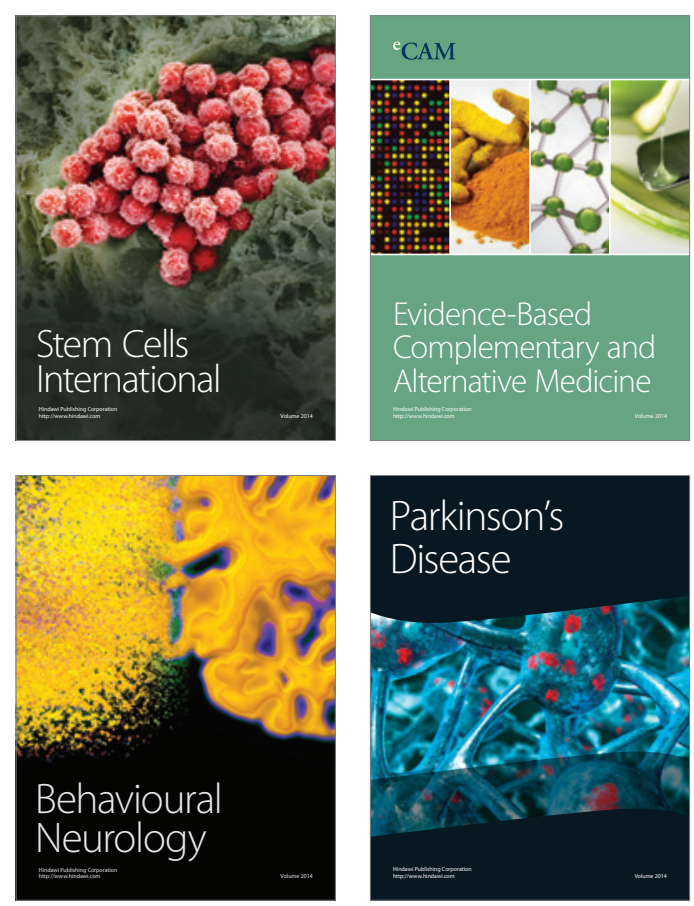

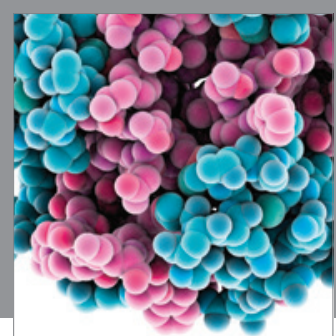

Journal of
Diabetes Research

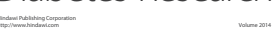

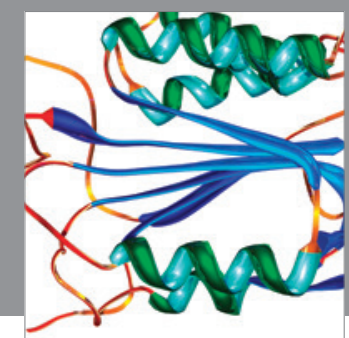

Disease Markers
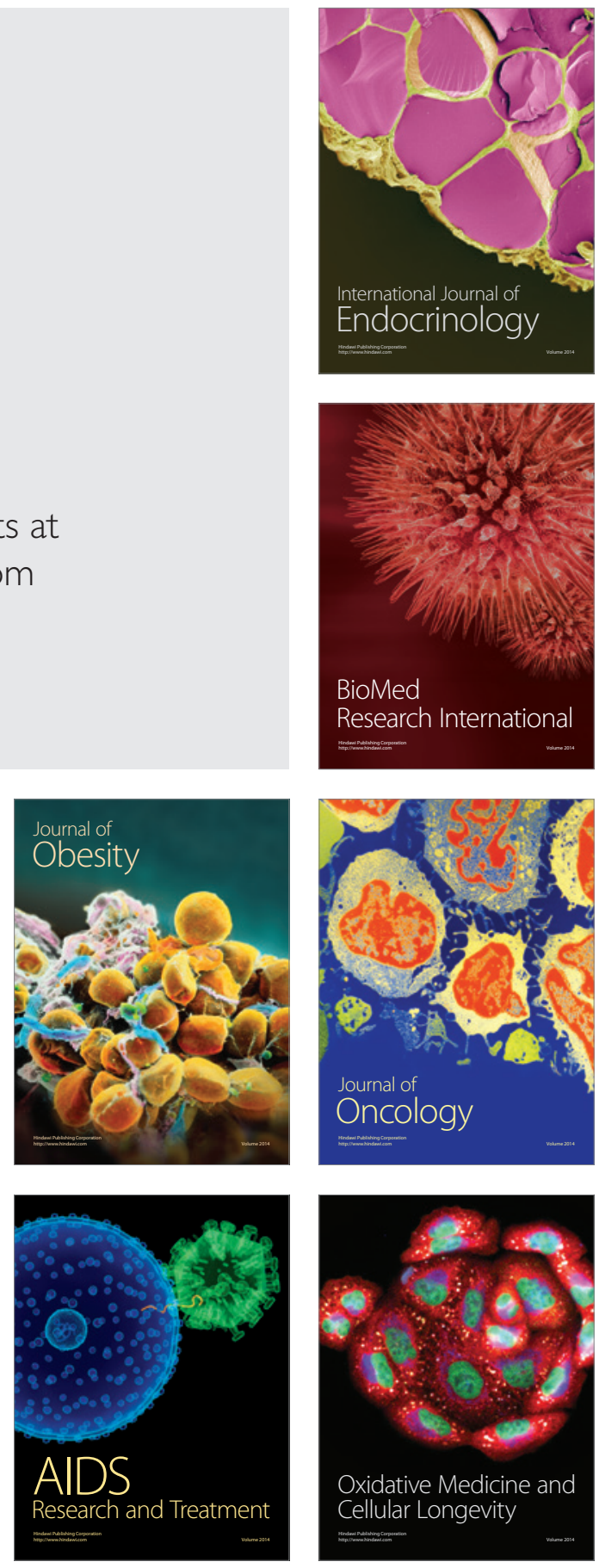